MARCOS VINÍCIUS MENDES SILVA

\title{
IMPLANTE DE CÉLULAS-TRONCO DE POLPA DENTÁRIA HUMANA ASSOCIADAS À BIOMATERIAIS PARA O REPARO DE LESÕES EM JOELHOS DE OVINOS
}




\section{IMPLANTE DE CÉLULAS-TRONCO DE POLPA DENTÁRIA HUMANA ASSOCIADAS À BIOMATERIAIS PARA O REPARO DE LESÕES EM JOELHOS DE OVINOS}

Dissertação apresentada ao Programa de PósGraduação em Anatomia dos Animais Domésticos e Silvestres da Faculdade de Medicina Veterinária e Zootecnia da Universidade de São Paulo para obtenção do título de Mestre em Ciências

Departamento:

Cirurgia

Área de Concentração:

Anatomia dos Animais Domésticos e Silvestres

Orientadora:

Prof $^{a}$. Dr ${ }^{a}$. Patrícia Cristina Baleeiro Beltrão Braga 
Autorizo a reprodução parcial ou total desta obra, para fins acadêmicos, desde que citada a fonte.

DADOS INTERNACIONAIS DE CATALOGAÇÃO-NA-PUBLICAÇÃO

(Biblioteca Virginie Buff D’Ápice da Faculdade de Medicina Veterinária e Zootecnia da Universidade de São Paulo)

Silva, Marcos Vinícius Mendes

Implante de células-tronco de polpa dentária humana associadas à biomateriais para o reparo de lesões em joelhos de ovinos / Marcos Vinícius Mendes Silva. -- 2011.

$122 \mathrm{f}$. : il.

Dissertação (Mestrado) - Universidade de São Paulo. Faculdade de Medicina Veterinária e Zootecnia. Departamento de Cirurgia, São Paulo, 2011. Silvestres.

Programa de Pós-Graduação: Anatomia dos Animais Domésticos e

Área de concentração: Anatomia dos Animais Domésticos e Silvestres.

Orientador: Profa. Dra. Patrícia Cristina Baleeiro Beltrão Braga.

1. Osteoartrite. 2. Célula-tronco de polpa dentária. 3. Terapia celular. 4. Biomateriais. 5. Ovinos. I. Título. 


\section{CERTIFICADO}

Certificamos que o Projeto intitulado "Implante de células-tronco de polpa de dente imaturas associadas a biolmateriais para reparo de lesões em joelhos de ovinos", protocolado sob o $\mathrm{n}^{\circ} 1736 / 2009$, utilizando 04 (quatro) carneiros, sob a responsabilidade da Profa Dra Patrícia Cristina Baleeiro Beltrão Braga, está de acordo com os princípios éticos de experimentação animal da Comissão de Bioética da Faculdade de Medicina Veterinária e Zootecnia da Universidade de São Paulo e foi aprovado em reunião de 19 de agosto de 2009.

We certify that the Research "Implant of human immature dental pulp stem cells associated with biomaterial to treat defects in ovine knee joint", protocol number 1736/2009, utilizing 04 (four) sheep, under the responsibility Profa Dra Patrícia Cristina Baleeiro Beltrão Braga, agree with Ethical Principles in Animal Research adopted by Bioethic Commission of the School of Veterinary Medicine and Animal Science of University of São Paulo and was approved in the meeting of day $08 / 19 / 09$.

São Paulo, 24 de agosto de 2009

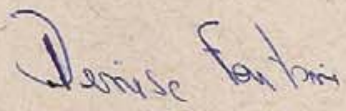

Profa Dra Denise Tabacchi Fantoni

Presidente da Comissão de Bioética FMVZ/USP 


\section{FOLHA DE AVALIAÇÃO}

Nome: SILVA, Marcos Vinícius Mendes

Título: Implante de células-tronco de polpa dentária humana associadas à biomateriais para o reparo de lesões em joelhos de ovinos

Dissertação apresentada ao Programa de Pós-Graduação em Anatomia dos Animais Domésticos e Silvestres da Faculdade de Medicina Veterinária e Zootecnia da Universidade de São Paulo para obtenção do título de Mestre em Ciências

Data: 1

\section{Banca Examinadora}

Prof. Dr.

Instituição:

Assinatura:

Julgamento:

Prof. Dr.

Instituição:

Assinatura:

Julgamento:

Prof. Dr.

Instituição:

Assinatura:

Julgamento: 
O mundo está nas mãos daqueles que têm coragem de sonhar, e correr o risco de viver seus sonhos (Paulo Coelho) 


\section{DEDICATÓRIA}

A minha mãe, Ilza Rosa Silva, por ter me incentivado, apoiado e ter me proporcionado mais esta alegria. Sem ela não conseguiria ter concluído mais esta etapa da minha vida.

"Obrigado mãe, pelo exemplo de vida"

Esta vitória também é sua...

Coloque amor em todo seu caminho e lute! Vale a pena!

Aos meus irmãos Fernando Cézar Mendes Silva e Wilze Lidyane Mendes Silva por todo amor, carinho e por sempre terem apoiado meus estudos. 


\section{AGRADECIMENTOS}

Nenhuma conquista tem significado pleno, se não for partilhada com as pessoas que nos ajudaram nessa caminha (Chiara Lubich).

A Deus por ter me guiado, dado forças para enfrentar todos os obstáculos com os quais me deparei e ter me agraciado com vida e saúde. Nos momentos difíceis sempre me deu a mão e indicou o caminho a seguir.

À Faculdade de Medicina Veterinária e Zootecnia pela oportunidade da realização da pós-graduação.

À minha orientadora, Profa. Dra. Patrícia Cristina Baleeiro Beltrão Braga, pela convivência, compreensão e amizade durante esses anos. Agradeço por ter confiado em mim e acreditado em nossa pesquisa. Sempre tenho aprendido muito com você. Obrigado pela paciência, serenidade e dedicação para comigo, pois soube unir sabedoria para me orientar neste trabalho.

À Profa. Dra. Maria Angélica Miglino pela oportunidade da pós-graduação.

À Dra. Graciela Conceição Pignatari pela dedicação, compreensão, ensinamentos e apoio durante esses anos de pós-graduação.

Ao Dr. Daniel Seitz, que em parceria com a Friedrich-Baur-Forschungsinstitut für Biomaterilien/ Universitat Bayreuth e Biocer entwicklungs, da Alemanha, produziram os biomateriais utilizados neste trabalho, obrigado pelas sugestões.

Ao Prof. Dr. Stefano Carlo Filipoo Hagen pelos conselhos, ensinamentos e por sempre me prestar auxílio quando necessário. Obrigado pelos momentos descontraídos e pelas explicações durante a realização dos exames ultrassonográficos, com certeza foram únicos. 
Ao Prof. Dr. Luiz Cláudio Lopes Correia da Silva, pela colaboração, compreensão e sugestões durante a execução deste trabalho. Obrigado pela realização dos exames artroscópicos e pelo apoio neste projeto.

Ao Prof. Dr. Franklin de Almeida Sterman (in memorian) pelos ensinamentos, questionamentos e apoio durante este trabalho, pois sem sua ajuda não teria conseguido a realização dos exames radiográficos. Sempre terei boas lembranças suas.

À Profa. Dra. Silvia de Campos Boldrini (in memorian), pelo incentivo, colaboração, pelas idéias e sugestões durante a realização deste trabalho. Sempre me acolheu de braços abertos em seu laboratório e teve paciência em suas explicações minuciosas. Obrigado por tudo! Deixou saudades.

À Dra. Silvana Maria Unruh pelo apoio prestado desde o início deste projeto, auxiliando nas questões burocráticas para a realização dos exames radiográficos e posteriormente realizando os mesmos. Obrigado pelo constante incentivo, dedicação e por sempre ter acreditado neste trabalho.

À funcionária, Marta Maria da Silva Righetti pela paciência, dedicação e amizade, pois com você aprendi muito. Sempre descontraída, disposta e com palavras otimistas. Obrigado por tudo!

À funcionária Rose Eli Grassi Rici pela realização da microscopia eletrônica de varredura deste trabalho.

Aos secretários, Jaqueline Martins de Santana, Fabiana Azevedo Fernandes, Maicon Barbosa da Silva, Maria Fátima Lourdes Minari, aos técnicos Diogo Nader Palermo, Edinaldo Ribas farias e a funcionária pelo convívio diário e ensinamentos.

Às funcionárias, Bernadete Ribeiro da Silva e Genilda Maria da Conceição por terem me acompanhado durante esta trajetória. Obrigado pelos bons momentos de convivência e descontração. 
Ao Matheus Levi Tajra Feitosa pelo auxílio no início deste trabalho, definindo assuntos importantes para a realização do mesmo.

Ao Paulo José Riccio Frazão (Cazé), pelo apoio durante a realização dos exames ultrassonográficos e pelo auxílio durante este trabalho.

À Bruna Cecília Caixeta de Oliveira por ter me recebido muito bem no laboratório da professora Silvia Boldrini e pelo apoio prestado.

À Karla Patrícia Cardoso Araújo, pelos anos de convivência durante a graduação e pós-graduação, por ter me proporcionado a oportunidade de conhecer a minha orientadora e por ter me acolhido desde que aqui cheguei. Você sempre será muito especial!

À Caroline Pinho Winck (Carol), pela paciência, compreensão, confiança e amizade sincera durante estes anos. Sempre me acompanhou em vários momentos, tristes ou alegres e me confortava com palavras sábias. Obrigado por tudo!

À Adriana Pinheiro da Franca, pelo convívio e amizade.

Ao José Luiz Nogueira (Nogueira), pela amizade sincera, conselhos e palavras sábias nos momentos necessários. Valeu!

À Renata Avancini Fernandes Nogueira (Rê), pelos bons momentos, sinceridade, amizade e disponibilidade. Obrigado pela ajuda nos momentos finais da construção deste trabalho.

À Larissa Fernandes Nogueira, por ter vindo alegrar a todos que estão em sua volta. Gosto muito de você!

Ao Kaio Barros Bezerra (Kaiera's), pelo convívio diário, amizade e apoio durante esta fase da minha vida. Sempre disposto e auxiliando no que fosse 
preciso. Obrigado por tudo que tem feito por mim e pela contribuição em meu trabalho.

À Lívia, pelo convívio nos finais de semana.

Ao Rafael Garabet Agopian pela amizade durante estes anos e por ter auxiliado na realização deste trabalho. Sempre prestativo e nunca consegue negar um favor. Obrigado pelos conselhos e ensinamentos.

À Dilayla Kelly de Abreu (Isaura), pelos bons momentos vivenciados durante a pós-graduação e pela amizade que vem se concretizando cada dia que passa.

Ao Valdir Pavanelo Júnior (Pavanelo), pelo apoio prestado neste experimento e pela amizade, que demorou, mas saiu.

À Bruna Pacheco (Enrica's), pelo convívio diário, momentos descontraídos e pela amizade. Ainda teremos muitas histórias por aqui.

Às minhas colegas de laboratório Isabella Rodrigues Fernandes e Fabiele Baldino Russo, Sílvia Amélia Ferreira Lima pelo apoio neste projeto.

À Elaine (Melaine), pela amizade e pelos bons momentos descontraídos.

Ao Thiago Pinheiro Arrais Aloia, pelo apoio prestado sempre que solicitado e amizade. Sempre tranquilo, poucas palavras, mas bons conselhos.

Ao Carlos A. P. Sarmento e Caio Biasi, pelos momentos vivenciados durante a pós-graduação.

À Janaína Munuera Monteiro pela amizade e pelos bons momentos vivenciados durante a pós-graduação. 
À Sonia Elisabete Alves de Lima Will, pelos bons momentos vividos durante a pós-graduação.

Ao Evander Bueno de Lima, pela amizade e momentos descontraídos.

Aos meus tios Andrey Márcio Silva, Wilson Ferreira, Eni, Marlene Rosa e primos Wilney Fernando Silva, Stefania Aparecida Silva, Suiara Leilanny Silva Gomes que sempre me incentivaram para conclusão de mais uma etapa na minha vida. Quantas alegrias e sofrimentos compartilhamos!

Aos meus afilhados Pedro Henrique Gonçalves Pereira ( $\mathrm{Peu}$ ) e Anamaria por sempre entenderem a minha ausência, devido a distância, em prol da realizações dos meus sonhos. Vocês são especiais!

À Priscila Gonçalves Pereira (Pri), que sempre ouviu minhas histórias vivenciadas durante a pós-graduação e ter me incentivado sempre a continuar lutando pelos meus ideais.

À Fernanda Maria de Jesus e José Antonino pelo apoio, carinho e por terem me acompanhado em mais esta etapa.

Ao Leonardo Gonçalves Pereira, Maria Inês e Pedro Ramos, pelo apoio.

Aos meus amigos mineiros Alexandre Eusébio, Alekson Mendonça, Felipe, Bruno, Talita Pina, Mayara Camila, Michele Araújo, Tania Mara Pina, que mesmo distante sempre me apoiaram e torceram para que este momento se concretizasse a caminho de uma nova etapa. Vocês são inesquecíveis!

À minha madrinha Elita, por sempre ter comemorado minhas vitórias e torcer pelo meu sucesso.

À Roberta Oliveira Macedo, Adriana Fernandes e Tatiana Dalcun, pela amizade, desde a graduação e que mesmo distante sempre estiveram torcendo por mim. A distância jamais vai nos separar. 
Ao Conselho Nacional de Desenvolvimento Científico e Tecnológico (CNPq), pela bolsa concedida durante estes anos de mestrado.

Às pessoas que aqui conheci, obrigado pelo convívio, constante incentivo e apoio.

Às pessoas que aqui não estão citadas, mas que me apoiaram e ajudaram na realização deste trabalho, obrigado.

"O valor das coisas não está no tempo em que elas duram, mas na intensidade com que acontecem. Por isso, existem momentos inesqueciveis, coisas inexplicáveis e pessoas incomparáveis (Fernando Pessoa)." 


\section{RESUMO}

SILVA, M. V. M. Implante de células-tronco de polpa dentária humana associadas à biomateriais para o reparo de lesões em joelhos de ovinos. [Implantation of stem cells from human dental pulp associated with biomaterials in joint damage in sheep]. 2011. $122 \mathrm{f}$. Tese (Mestrado em Ciência) - Faculdade de Medicina Veterinária e Zootecnia, Universidade de São Paulo, São Paulo, 2011.

A terapia celular com células-tronco (CT) surgiu nos últimos anos como uma esperança para o tratamento de doenças, sem tratamento efetivo, como a osteoartrite (OA) em joelho. Nesse trabalho utilizamos células-tronco imaturas de polpa dentária humana (CTPD) cultivadas ou não em associação com biomateriais para o tratamento de lesões osteoarticulares em joelhos de ovinos. As CTPD humanas foram transduzidas com o gene repórter, EGFP, facilitando o monitoramento das mesmas in vitro e in vivo, após o implante na articulação femorotibiopatelar de ovinos. A capacidade de adesão e acomodação das células de polpa dentária no biomaterial foi observada in vitro 24 horas e um mês após sua aplicação no mesmo, sendo a viabilidade celular semelhante em ambos os períodos, porém com uma maior dispersão celular no período mais longo, segundo as análises realizadas por técnicas de microscopia eletrônica de varredura e histologia. Ainda para a realização das análises histológicas, foram realizadas técnicas para padronizar os métodos de descalcificação e inclusão do tecido ósseo-articular, prévio aos cortes. Exames radiográficos, ultrassonográficos e artroscópicos foram feitos para acompanhar a evolução dos tratamentos. Os resultados revelaram que as CTPD humanas aderem bem ao biomaterial e que em associação possuem uma excelente capacidade aparente de reconstituição do tecido lesado. Com a realização deste trabalho, concluímos que o protocolo de terapia utilizado é um bom modelo para o estudo de OA e serve para futuras aplicações clínicas.

Palavras-chave: osteoartrite, célula-tronco de polpa dentária, terapia celular, biomateriais, ovinos. 


\section{ABSTRACT}

SILVA, M. V. M. Implantation of stem cells from human dental pulp associated with biomaterials in joint damage in sheep. [Implante de células-tronco de polpa dentária humana associadas à biomateriais para o reparo de lesões em joelhos de ovinos]. 2011. $122 \mathrm{f}$. Tese (Mestrado em Ciência) - Faculdade de Medicina Veterinária e Zootecnia, Universidade de São Paulo, São Paulo, 2011.

Cell therapy with stem cells (CT) has emerged in recent years as a hope for the treatment of diseases without effective treatment, such as osteoarthritis $(\mathrm{OA})$ in knee. In this work we use stem cells from immature human dental pulp (hSCIDP) in association or not with biomaterials for the treatment of osteoarticular lesions in sheep's kneef. The human hSCIDP were transduced with the reporter gene EGFP, thus making easier monitoring these in vitro and in vivo after implantation in sheep's femorotibiopatelar joint. The capacity of adhesion and accommodation of dental pulp cells in the biomaterial in vitro was observed $24 \mathrm{~h}$ and one month after its application, resulting in similar cell viability in both periods, but with a greater cell dispersion in the longer, period, according to analysis performed by scanning electron microscopy and histology. Moreover, some histological techiniques were performed to standardize the methods for inclusion and decalcification of bone tissue joints. Radiographic, ultrasonographic and arthroscopic analyses were made to monitor the progress of treatment. The results revealed that the human hSCIDP adhere well to the biomaterial and have an excellent apparent reconstitution of damaged tissue. With this work, we conclude that the therapy protocol used is a good model for studying OA and useful for future clinical applications.

Keywords: osteoarthritis, dental pulp stem cell, cell therapy, biomaterials, sheep. 


\section{LISTA DE ABREVIATURAS}

$\%$ - porcento

${ }^{\circ} \mathrm{C}$ - grau Celsius

$\mu g$ - microgramas

$\mu \mathrm{m}-$ microlitros

$\mathrm{CO}_{2}$ - dióxido de carbono

DMEM/F12 - Dulbecco's Modified Eagle Medium/ F12

$\mathrm{HE}$ - hematoxilina-eosina

$\mathrm{M}$ - molar

MEM NEEA - aminoácidos não essenciais (medium essential media nonessencial amino acids)

$\mathrm{mL}-$ mililitros

$\mathrm{mM}$ - milimolar

PBS - tampão salina fostato (Phosphate Buffered Saline)

rpm - rotação por minuto

SFB - soro fetal bovino

CT - células-tronco

OA - osteoartrite

CTPD - células-tronco de polpa dentária humana

EGFP - proteína fluorescente verde (Enhanced Green Fluorescent Protein)

CTE - células-tronco embrionárias

CTMs - células-tronco mesenquimais

CTG - células-tronco germinativas

CTA - células-tronco adultas

SHED - células-tronco de decíduos esfoliado humano

$\mathrm{pH}$ - potencial hidrogeniônico

HA - hidroxiapatita

GAG - glicosaminoglicanos

C6S - condroitin-6-sulfato

C4S - condroitin-4-sulfato

DAPI - 40,6-diamidino-2-phenylindol

DMEMc - DMEM completo

g-gramas 
EDTA - ácido etileno diaminotetracético

$\mathrm{mg}$ - miligramas

$\mathrm{Kg}$ - quilogramas

IV - via intravenosa

$\mathrm{mA}$ - miliampéres

MMA - metilmetacrilato

RDO - SAFE CONTROLLABLE DECALCIFIER GOLD

MEV - microscopia eletrônica de varredura 


\section{SUMÁRIO}

1. INTRODUÇÃO__ 19

2 REVISÃO DE LITERATURA _ 23

2.1 CÉLULAS-TRONCO _ 23

2.2 CÉLULAS-TRONCO MESENQUIMAIS___ 24

2.3 CÉLULAS-TRONCO DE POLPA DENTÁRIA HUMANA___ 24

2.4 BIOMATERIAIS _ 25

2.5 DOENÇAS ÓSSEO-ARTICULARES___ 29

3 OBJETIVOS 34

3.1 OBJETIVOS GERAIS __ 34

3.2 OBJETIVOS ESPECÍFICOS __ 34

4 MATERIAIS E MÉTODOS _ 35

4.1 CÉLULAS _ 35

4.2 BIOMATERIAL__ 35

4.3 MODELO ANIMAL__ 36

4.4 PREPARO DAS CÉLULAS-TRONCO DE POLPA DENTÁRIA PARA

IMPLANTAÇÃO NOS ANIMAIS ASSOCIADAS OU NÃO AO BIOMATERIAL _ 37

4.5 ANÁLISE DA ADESÃO DAS CÉLULAS AO BIOMATERIAL __ 38

4.5.1 Análise do porcentual de adesão das CTPD ao biomaterial por contagem de

células 38

4.5.2 Análise histológica do biomaterial associado ou não as CTPD __ 38

4.5.3 Análise por microscopia eletrônica de varredura (MEV) do___ 39

4.6 PROCEDIMENTO CIRÚRGICO DE IMPLANTAÇÃO DAS CÉLULAS

ASSOCIADAS OU NÃO AO BIOMATERIAL__ 39

4.6.1 Protocolo Anestésico _ 40

4.6.2 Procedimento Cirúrgico 40

4.6.3 Cuidados Pós-Cirúrgicos 42

4.7 MONITORAMENTO CLÍNICO DOS ANIMAIS TRATADOS COM _ 42

4.7.1 Exame Radiográfico 42

4.7.2 Exame Ultrassonográfico___ 43

4.7.3 Exame de Artroscopia — 43

4.7.4 Exames bioquímicos e hemograma__ 45

4.8 ANÁLISE HISTOLÓGICA DA ARTICULAÇÃO FEMOROTIBIOPATELAR DOS OVINOS SUBMETIDOS AO TRATAMENTO COM BIOMATERIAL ASSOCIADO OU

NÃO A CTPD — 46

4.8.1 Descalcificação Óssea _ 46

4.8.1.1 Descalcificação com Ácido Etílico Tetra-Acético (EDTA) __ 47

4.8.1.2 Descalcificação com Solução de Morse __ 47

4.8.1.3 Descalcificação utilizando o descalcificador rápido (Safe Controllable
Decalcifier Gold - RDO)

4.8.2 Procedimentos histológicos para a análise do material submetido ao processo

de descalcificação _ 49

4.8.2.1 Colorações 50

4.8.2.1.1 Hematoxilina-Eosina__ 50

4.8.2.1.2 Coloração de Picrosírius___ 51 
4.8.2.1.4 Coloração de Safranina

4.8.2 Inclusão da articulação femorotibiopatelar em Metilmetacrilato (MMA) __ 52

5 RESULTADOS 54

5.1 CÉLULAS-TRONCO DE POLPA DENTÁRIA HUMANA 54

5.2 BIOMATERIAL 55

5.3 Análises do Biomaterial associado ou não as CTPD 56

5.3.2 Análise do potencial de adesão das células ao biomaterial

5.3.3 Análise histológica do biomaterial associado ou não as CTPD __ 57

5.3.3.1 Análise histológica da parte de quitosana do biomaterial 58

5.3.3.1.1 Coloração de HE

5.3.3.1.2 Coloração de Picrosírus

5.3.3.1.3 Coloração de azo-carmin — 60

5.3.3.1.4 Coloração de safranina

5.3.3.2 Análise histológica da parte de quitosana do biomaterial associada as CTPD

5.3.3.2.1 Coloração de HE

5.3.3.2.2 Coloração de picrosírus

5.3.3.2.3 Coloração de azo-carmin

5.3.3.2.4 Coloração de safranina

5.3.4 Análise do biomaterial associado ou não as CTPD por 68

5.3.4.1 Biomaterial não associado a CTPD _ 68

5.3.4.2 Biomaterial associado a CTPD

5.4 PROCEDIMENTO CIRÚRGICO DE IMPLANTAÇÃO DAS CÉLULAS ASSOCIADAS OU NÃO AO BIOMATERIAL 70

5.5 Monitoramento clínico dos animais tratados com biomateriais associados ou não as CTPD humanas

5.5.1 Exame Radiográfico 71

5.5.2 Exame Ultrassonográfico 71

5.5.3 Exame de Artroscopia 79

5.5.4 Exames Bioquímicos e Hemograma

5.6 ANÁLISE HISTOLÓGICA DA ARTICULAÇÃO FEMOROTIBIOPATELAR DOS OVINOS NÃO TRATADOS SUBMETIDOS A DIFERENTES PROTOCOLOS DE DESCALCIFICAÇÃO

5.6.1 Análise histológica após descalcificação com EDTA A 10\%___ 91

5.6.1.1 Coloração de HE

5.6.1.2 Coloração de Picrosírius _ 92

5.6.1.3 Coloração de Azo-Carmim _ 94

5.6.2 Análise histológica após descalcificação com solução Morse __ 95

5.6.2.1 Coloração de HE

95

5.6.2.2 Coloração de Picrosírius __ 96

5.6.2.3 Coloração de azo-carmin 97

5.6.3 Análise histológica após descalcificação óssea utilizando a ___ 98

5.6.3.1 Coloração de HE

99

5.6.3.2 Coloração de Picrosírius __ 99

6 DISCUSSÃO 101

7 CONCLUSÕES__ 106

REFERÊNCIAS 108 


\section{INTRODUÇÃO}

Nos últimos anos, com o avanço do conhecimento e das técnicas moleculares, a ciência conseguiu gerar informações importantes para o diagnóstico e tratamento de uma série de doenças outrora sem tratamento (NOLAN et al., 2008), como as doenças ósseas (BOELONI et al., 2009). Um novo ramo da medicina, a chamada medicina regenerativa, criou novas esperanças de tratamento para essas doenças através da terapia celular com células ainda não-diferenciadas conhecidas como células-tronco (CT) (NOLAN et al., 2008). A terapia celular é um método que vem sendo estudado para enfrentar situações relacionadas com diversos tecidos e órgãos do corpo, cujo objetivo é restabelecer o funcionamento normal desse tecido repovoando-o através das $\mathrm{CT}$.

As CT matem a habilidade de se diferenciar em tipos celulares específicos (LEITE SEGUNDO; VASCONCELOS; 2007) e são capazes de sobreviver ao longo de toda a vida no organismo, mantendo seu número, produzindo populações de células filhas (LEVIN et al., 2004). Elas estão presentes no corpo em nichos como a medula óssea, a polpa de dente e outros tecidos de forma mais distribuída e em menor número, como a pele, músculo, aderidas aos vasos sanguíneos entre outros (ZATZ, 2004; LEITE SEGUNDO; VASCONCELOS, 2007). Na fase embrionária são consideradas pluripotentes, pois podem gerar todos os tipos celulares presentes no corpo humano, podendo então reconstruir qualquer tecido do organismo humano (KIRSCHSTEIN; KIRBOLL, 2001). O potencial ilimitado de auto-renovação, proliferação, a capacidade de responder a estímulos externos e de originar linhagens celulares com diferentes funções impulsionaram pesquisas sobre as aplicações terapêuticas dessas células (KIRSCHSTEIN; SKIRBOLL, 2001; GARRY et al., 2003; SCADDEN, 2006; LEAL, 2007; PEREIRA, 2008; LOTTENBERG; MOREIRA FILHO, 2009). Já, as CT encontradas na fase adulta têm uma plasticidade mais limitada sendo consideradas multipotentes (FUCHS; SEGRE, 2000; PEREIRA, 2008). Em 1981, as primeiras célulastronco embrionárias (CTE) pluripotentes foram isoladas por cultura in vitro, 
derivadas do interior da massa celular de blastocistos de ratos (WAGERS, 2004). Contudo, somente em 1998, a equipe do biólogo James Thomson conseguiu isolar CTE humanas (THOMSON et al., 1998).

As primeiras aplicações terapêuticas com CT foram feitas com células multipotentes derivadas de tecidos adultos, tanto em transplantes autólogos como em heterólogos (LO et al., 2003; GARRY et al., 2003; OKAMOTO; MOREIRA FILHO, 2004; LOTTENBERG; MOREIRA FILHO, 2009). Os transplantes autólogos são constituídos de células modificadas do próprio indivíduo e o heterólogo usa as células de um doador da mesma espécie. Nem sempre é possível realizar um transplante autólogo, sendo mais freqüente o heterólogo, processo que pode levar à rejeição do enxerto. Vale ressaltar que o ideal seria utilizar células que não estimulassem a resposta imunológica, qualidade que tem sido apontada nas células-tronco mesênquimais (CTMs).

A polpa dentária dos dentes decíduos possui CTMs e apresentam grande potencial terapêutico para o uso em ortopedia. Essas células ainda possuem outras características que as tornam atraentes para uso em terapia celular, como a fácil obtenção, a facilidade no cultivo celular, alta habilidade de proliferação e diferenciação in vitro em várias linhagens celulares e, ainda, boa interatividade com biomateriais (KERKIS et al., 2006; SLOAN; SMITH, 2007; D'AQUINO et al., 2008). As células-tronco de polpa dentária (CTPD) humana têm alta capacidade de diferenciação nas linhagens condrogênicas, osteogênicas, neurogênicas, miogênicas in vitro (KERKIS et al., 2006; KERKIS et al., 2008). Além disso, as CTPD humana foram injetadas em outras espécies animais e apresentaram ótima incorporação como enxerto em vários tecidos, com grande potencial terapêutico e sem induzir resposta imunológica (KERKIS et al., 2006, MONTEIRO et al., 2009, GOMES et.al., 2010).

Atualmente, alguns trabalhos têm mostrado a associação de CT com biomateriais. A engenharia de biomateriais tem se mostrado uma forte aliada na terapia celular, pois os biomateriais podem dar suporte às células aumentando a sobrevivência após o transplante e ainda podem permitir que a diferenciação seja maior e eficiente. O desenvolvimento e análise de novos 
biomateriais são de fundamental importância para estudar as interações com diferentes células e para que haja a otimização dos processos de regeneração tecidual e aumento da biocompatibilidade dos materiais (HELMUS et al., 2008; WILLIAMS, 2008;).

Nos últimos anos, uma grande variedade de biomateriais vem sendo desenvolvida com diferentes propriedades físico-químicas e mecânicas, dependendo da aplicação prevista, incluindo regeneração tecidual, novos enxertos vasculares, ou suportes para engenharia de tecidos in vitro e in vivo (RATNER, 2004; SERRANO et al., 2004; CZAJA et al., 2007).

Dentro do cenário de doenças onde a medicina regenerativa apareceria como uma forma de tratamento alternativo para a cura, a osteortrite (OA) é considerada uma delas. A OA é uma doença articular crônico-degenerativa que evidencia desgaste da cartilagem articular, na qual, dentre as articulações, o joelho é o mais freqüentemente afetado (MARTIN, 1994 apud KAM, 2006). Ela é vista como uma perturbação crônica das articulações caracterizada pela degeneração da cartilagem e do osso adjacente, que pode causar dor articular e rigidez. Clínica e radiograficamente, caracteriza-se por dor, rigidez matinal, crepitação óssea, atrofia muscular, estreitamento de espaço intra-articular, formações osteofíticas, esclerose do osso subcondral e formações císticas (ALTMAN, 1986 apud KAM, 2006).

Independente da idade, o risco de OA aumenta com o tamanho do defeito preliminar da cartilagem ou de ferimento comum. Entretanto, este risco pode ainda aumentar com os danos colaterais, tais como: lesão no menisco ou instabilidades do ligamento (CURL et al., 1997 apud FRITZ et al., 2008). Apesar das diversas opções terapêuticas, nenhuma solução ideal foi encontrada para $\mathrm{o}$ tratamento de defeitos condrais e osteocondrais (MARTINEK et al., 1999).

O presente trabalho propõe a utilização da terapia celular com célulastronco mesenquimais de polpa dentária humana, associadas ou não a biomateriais para a possível regeneração óssea-cartilaginosa de lesões no joelho de ovinos. A escolha das CTPD para esse projeto advém do fato que avanços significativos têm sido feitos em regeneração óssea com o uso de CTMs (YAMATO; OKANO, 2004 apud BARBANTI et. al., 2005; COSTA et al., 2008). Como estas células foram transduzidas com vírus EGFP, elas poderão 
ser rastreadas após sua implantação, para que se possa comprovar sua presença in vivo e assim observar o seu efeito terapêutico nos animais. 


\section{REVISÃO DE LITERATURA}

\subsection{CÉLULAS-TRONCO}

Existem três fontes primárias de CT, cada uma com características diferentes quanto à sua contribuição no desenvolvimento e no funcionamento do organismo. As células-tronco embrionárias (CTE) são derivadas da mórula ou do blastocisto, enquanto que as células-tronco germinativas (CTG) são coletadas em um estágio um pouco mais avançado do desenvolvimento embrionário, a partir do tecido fetal.

No decorrer da vida, organismos adultos apresentam alta capacidade de regeneração em resposta a diferentes tipos de injúrias e/ou patologias. Isso ocorre devido à presença de um tipo especifico de células localizadas em cada órgão (nicho), as quais são denominadas células-tronco adultas (CTA); definidas como células com capacidade de auto-renovação, diferenciando-se para diversos tipos celulares funcionais. Além disso, estudos recentes sugerem que as CTA também podem exercer a função de imunossupressão (KEATING, 2006; NARDINI; MEIRELLES, 2006). Em contraste com as CTE, as CTA não podem gerar um organismo inteiro. Convém ressaltar que, neste momento, apenas CTA humanas são bem compreendidas e capazes de se diferenciar em tipos específicos de tecidos sem a produção de teratomas e que, por isso, as CTA precederam os ensaios clínicos.

O termo terapia celular pode ser definido como um procedimento médico que visa restabelecer a estrutura e a função de um tecido, por meio da utilização de uma célula ou de uma população de células. As intervenções médicas regenerativas ainda têm grandes limitações técnicas e biológicas. Assim, tais limitações motivam os cientistas a explorarem, cada vez mais, as relações entre os mecanismos biológicos e a bioengenharia (CAPLAN, 2005).

A aplicação de CT em doenças ósseas ainda encontra-se na fase experimental (TAE et al., 2006). Estas células têm sido utilizadas no tratamento de OA (LUYTEN, 2004), osteonecrose (LEE et al., 2003), fraturas (OREFFO; TRIFFITT, 1999) dentre outros. 


\subsection{CÉLULAS-TRONCO MESENQUIMAIS}

As CTMs são células não-hematopoiéticas e atualmente é o tipo mais provável de CT a serem utilizadas na prática de clínica, devido a sua fácil acessibilidade e multipotencialidade de diferenciação em vários tecidos (CAPLAN; BRUDER, 2001; TORQUETTI et al., 2007).

A denominação mesenquimal foi proposta quando se verificou a habilidade dessas células em originar múltiplos tecidos derivados do mesoderma, ou seja, com as mesmas propriedades do mesenquima embrionário primitivo (BIANCO et al., 2006).

A capacidade de expansão das CTMs em cultura tem facilitado o desenvolvimento para avaliar segurança, as características e a eficácia dos transplantes destas células para uma variedade de doenças. Fatores como lesão, multipotencialidade, proliferação, interação e indução de células locais determinam o destino dessas células (DEVINE, 2002).

As células-tronco de polpa dentária humana são uma fonte de CTMs, derivadas da crista neural, recentemente descoberta, e com possibilidades terapêuticas promissoras (MONTEIRO et al., 2009). Elas possuem a capacidade de se diferenciar em várias linhagens celulares distintas, tanto in vitro quanto e in vivo (GRONTHOS et al., 2002; HAU et al., 2006) e apresentam uma morfologia típica de fibroblasto (YAMAMURA, 1985).

\subsection{CÉLULAS-TRONCO DE POLPA DENTÁRIA HUMANA}

Os tecidos dentais são fontes de fácil acesso de diferentes tipos de CT. As CT derivadas desses tecidos são, na maioria, de origem ectomesenquimal, provenientes da crista neural, com a exceção do epitélio dental que é oriundo do ectoderma. As CT extraídas de polpa dentária, CTPD, são multipotentes, altamente proliferativas e clonogênicas. Sendo de fácil acesso e retiradas com mínimo desconforto para o paciente. Assim, as CTPD tornam-se uma fonte atrativa para ensaios clínicos e medicina regenerativa. Diversas populações de CT foram isoladas a partir de polpa dentária de dentes permanentes, decíduos e supranumerários (GRONTHOS et al., 2000; GRONTHOS et al., 
2002; MIURA et al., 2003; LAINO et al., 2005; PIERDOMENICO et al., 2005; KERKIS et al., 2006; HUANG et al., 2008).

A primeira descrição das CTPD foi feita através da presença de células indiferenciadas na polpa do dente de ratos, as quais foram capazes de se diferenciar em odontoblasto, e subsequentemente produziram uma matriz de dentina (YAMAMURA, 1985).

Em 2000, Gronthos et al. isolaram uma população clonogênica e proliferativa das CTPD humana, classificando-as imunofenotipicamente e em 2002 estudaram a capacidade de auto-regeneração, de diferenciação em multi-linhagem e a eficiência clonogênica das CTPD. Os autores demonstraram à capacidade de diferenciação destas células tanto em adipócitos quanto em células nervosas.

Em 2006, as CT imaturas de polpa dentária foram isoladas por explante em condições de cultivo similares as usadas para o isolamento de CTE (KERKIS et al., 2006). Essas células expressam marcadores de CTE humanas como Oct-4 (fator de transcrição do Octâmero-4), Nanog (fator de transcrição, e fator chave da pluripotência), SSEA-3 e 4 (antígenos embrionários estágio-específico), TRA-1-60, TRA-1-81(antígenos de reconhecimento tumoral) e marcadores de CTM: CD105 (SH2), CD73 (SH3 e $\mathrm{SH} 4), \mathrm{CD} 13$ e CD31. Ainda, as CTPD apresentam rápida proliferação, alta capacidade clonogênica, e não apresentaram resposta imunológica quando injetadas em animais não imunossuprimidos (KERKIS et al., 2006). Recentemente as CTPD foram testadas em ratos não imunossupressão para a reconstrução de defeitos cranianos produzidos e não obtiveram nenhuma rejeição (COSTA et al., 2008).

\subsection{BIOMATERIAIS}

Um material biológico tem sido definido, recentemente, como um material não vivo, natural ou sintético, capaz de estabelecer uma interação apropriada com o sistema biológico, sem induzir uma resposta adversa ao hospedeiro. Além de oferecerem suporte estrutural, propiciam um ambiente fisiológico adequado para as células e fatores bioquímicos (AHSAN; NEREM, 2005; ELISSEEFF et al., 2005; GOMES et al., 2008). Estes materiais 
conhecidos como biomateriais possuem a capacidade de substituir, aumentar ou tratar uma lesão.

O biomaterial utilizado em implantes não pode ser rejeitado, não pode causar resposta inflamatória, devendo ser, portanto, biocompatível (BUCKWALTER; MANKIN, 1998; CHEN; WU, 2005) e biodegradável (HOFFMANN et al., 2009). Além disso, ele pode promover a cura e a regeneração tecidual, e quando necessário, desaparecer depois de servir ao seu propósito, significando que o mesmo deve ser absorvido (BUCKWALTER; MANKIN, 1998; CHEN; WU, 2005).

Além das características mencionadas temos outras propriedades que qualificam um biomaterial. Dentre essas podemos citar a sua porosidade, as suas estabilidades química e mecânica, o seu $\mathrm{pH}$, a sua toxicidade, a sua biodegradabilidade, além da presença de cargas elétricas ou elementos que estimulem a adesão e migração celular (AROSARENA, 2005; ELISSEEFF et al., 2005; GOMES et al., 2008).

Os biomateriais utilizados para a reconstruções ósseas classificam-se em cerâmicos, poliméricos e metálicos (LOBO, 2002). Dentre esses, os cerâmicos, representado principalmente pela hidroxiapatita (HA) e pelos tricálcio-fosfatos são os mais utilizados por parecerem com a parte inorgânica do osso (LOBO, 2002; WANG, 2003; MANKANI et al., 2006).

Alguns tipos de tratamentos necessitam de um suporte constituído de biomateriais, para facilitar a restauração da estrutura e da função de tecidos danificados (LUTOLF; HUBBELL, 2005; LOBO et al., 2008). Desta maneira, algumas condições são determinantes para que se tenha um resultado. Os poros do suporte devem ter tamanhos e formas adequadas, além de estarem interligados para garantir os nutrientes necessários às células, favorecerem a integração no tecido e vascularização. Outro aspecto da material utilizado deve ser a biocompatibilidade e biodegradabilidade (HOFFMANN et al., 2009).

Os diferentes tamanhos dos poros de um biomaterial levam a importantes variações dos tecidos neoformados (COOMBES et al., 2004). A microporosidade de algumas biocerâmicas de HA tem a propriedade de formação do tecido ósseo, sem adição de células ou moléculas sinalizadoras em vários modelos animais (RIPAMONTI, 2000). A HA tem a capacidade de 
aumentar a formação e adesão de camada celular, isso devido a sua capacidade de adsorver proteínas (COOMBES et al., 2004).

Em 2010, da Silva et al. utilizando condrócitos bovinos conseguiram avaliar e caracterizar a formação extracelular da matriz em dois tipos de quitosana, um com suporte de poros pequenos e outro grandes. No suporte de poros grandes, observaram uma maior formação de proteoglicanos e colágeno do tipo II, mas a quantidade de glicosaminoglicanos foi menor, quando comparado com os de poros pequenos.

A biocompatibilidade dos biomateriais está relacionada com 0 comportamento das células em contato com eles e particularmente à adesão celular à sua superfície (ANSELME, 2000; HELMUS et al., 2008). As características de superfície dos biomateriais irão determinar quais moléculas biológicas serão adsorvidas. De acordo com isso e com a sua orientação na superfície, haverá um comportamento celular característico, com conseqüências diretas na adesão, proliferação e diferenciação das células, sendo que estes eventos dependem de diversos fatores químicos e biológicos para ocorrer (BOYAN et al., 1996). O conhecimento dos mecanismos básicos de interação célula-material e um melhor entendimento dos processos em níveis celulares, durante a interação das células, podem ajudar no desenvolvimento de novos biomateriais (KUMARI et al., 2002).

A adesão celular é mediada por diferentes tipos de proteínas receptoras transmembranares conectadas ao citoesqueleto celular (BAXTER et al., 2002). A adesão celular a um biomaterial está relacionada a dois fenômenos: fase de anexação e fase de adesão. A fase de anexação ocorre rapidamente e envolve eventos como ligações físico-químicas entre as células e o material, por forças iônicas e forças de Van der Walls. Já, a fase de adesão ocorre posteriormente e envolve a ligação de diversas moléculas biológicas como proteínas da matriz extracelular, de membrana celular e do citoesqueleto, que interagem conjuntamente para induzir a transdução do sinal, promovendo assim a ação dos fatores de transcrição e conseqüentemente regulando a expressão gênica (ANSELME, 2000).

Quando as células estão em contato com os biomateriais podem ocasionar morte do tecido, formação de um tecido fibroso, formação de 
ligação da superfície e também substituição pelo tecido receptor (DALBY et al.,2001).

Atualmente, algumas pesquisas relacionadas com biomateriais estão desenvolvendo novos suportes para contribuir com a medicina regenerativa, como a quitosana. Essa pode ser derivada do exoesqueleto de crustáceos, das paredes celulares de fungos e insetos (FREIER et al., 2005). É um biopolímero (polissacarídeo) conhecido, biodegradável e com algumas propriedades antibacterianas (KHOR; CHITIN, 2002; DI MARTINO; SITTINGER; RIBUD, 2005; DI MARTINO; SITTINGER; RISBUD, 2005). Ela pode ser degradada por enzimas em corpo humano (MI et al., 2002). Além disso, a quitosana pode ser moldada em várias formas e também associada com outros biomateriais (SHI et al., 2006). Para gerar um material de suporte, o polímero tem que ser feito de forma com que aumente a sua estabilidade (HSIEH et al., 2003).

Para reconstituição de cartilagem, muitos biomateriais já foram testados e atualmente encontramos em uso clínico, os hidrogéis de colágeno, ácido hialurônico e fibrina. Os avanços para o desenvolvimento dos estudos com substituição de cartilagem consistem em resolver tanto questões referentes à diferenciação quanto questões relacionadas à integração do implante. Mesmo para defeitos onde o osso não é afetado, o conceito de substituição osteocondral tem ganhado cada vez mais aceitação. É muito aceito que suporte ósseos podem facilmente integrar em regiões de lesão de osso encobertas por cartilagem, ocasionando uma melhor fixação do implante e integração no processo de remodelação óssea. Uma questão ainda não resolvida é a combinação entre o tecido macio da cartilagem e os implantes de tecidos ósseos duros. Além das forças verticais de resistência, a interface do suporte tem que ser estabilizada contra os movimentos laterais (LIMA et al., 2004).

Hoffmann et al. (2009), fizeram uma cultura com células em scaffold de quitosana e glutaraldeído, demonstrando que as células são capazes de diferenciar em condrócitos e a parte interna do suporte produzir colágeno.

Alguns estudos in vivo demonstraram um alto grau de biocompatibilidade do scaffold de quitosana em camundongos (VANDEVORD et al., 2002). Já em outros, utilizando coelhos, observou-se a formação de 
tecido hialino após o implante (FRENKEL et al., 2005) e em ovinos, a formação de condrócitos circundados por uma cartilagem semelhante a matriz hialina (MRUGALA et al., 2007).

A diferenciação atual não é satisfatória, levando a formação de colágeno II e glicosaminoglicanos (GAG), não livres para colágeno I e não integradas nas camadas estruturais corretas, vitais para a função da cartilagem. Integrações parecem quase impossíveis para a interface da cartilagem-cartilagem. Diversos fatores de crescimento, especialmente quando aplicados em combinação, podem estimular mecanicamente fornecendo bons resultados. O uso de fatores de crescimento in vivo, entretanto, traz problemas inevitáveis: normalmente possuem proteínas de origem xenobiótica e possuem estabilidade limitada. Além disso, pouco se sabe sobre a interação exata da ação e entre os fatores de crescimento no corpo. Muitos têm mais de uma função e podem induzir duas ações antagonistas ao mesmo tempo. Um exemplo é TGF $\beta$, que pode induzir vias autoregulatórias e levar a resposta antiinflamatória (CHEN; MENG, 2004; WAHL, 1994). Essas são importantes vias na formação da cartilagem, entre estas o TGF- $\beta$, IGF e FGF, que induzem vias que são simultaneamente ligadas à sinalização mediada por integrinas e sistemas de mecanotransdução. Deste modo, isto pode ser uma forma prática para programar a diferenciação de condrócitos via superfície de interação usando locais selecionados para integrinas específicas (WAHL, 1994; VARGHESE et al., 2008). Recentemente, foi demonstrado que a atividade condrogênica pode ser induzida sem fatores de crescimento através de mecanismos de estimulação em combinação com uma matriz que interage com as integrinas condrocíticas, nesse caso agarose (HUNG, 2004).

Por fim, o uso de biomateriais associados às CT pode ser uma alternativa terapêutica muito atraente no tratamento de lesões na cartilagem.

\subsection{DOENÇAS ÓSSEO-ARTICULARES}

Existem diversas doenças que atingem os ossos e a cartilagem, seja por causa do desgaste físico, pelo processo de envelhecimento ou por alguma ruptura. Desta maneira, torna-se necessário o desenvolvimento de 
estudos para poder tratá-las de uma maneira mais eficiente, pois algumas doenças que destroem a parte óssea e cartilaginosa permanecem ainda sem tratamento efetivo.

Uma dessas doenças que afetam a cartilagem é a osteoartrite (OA), resultante de eventos que desestabilizam a ligação normal de degradação e síntese dos condrócitos da cartilagem articular, matriz extracelular e osso subcondral. A OA é um distúrbio musculo esquelético geralmente insidioso, que leva a uma incapacidade funcional progressiva (FELLET; FELLET; FELLET, 2007). As evidências clínicas são caracterizadas por dor articular, limitação de movimento, crepitação, efusões ocasionais e variáveis graus de inflamação. O processo patológico da doença ativa afeta todos os tecidos da articulação, levando a uma alteração metabólica local, alterando o processo de reparo tecidual e culminando com uma insuficiência articular (SHARMA; ELISSEEFF, 2004; FELLET; FELLET; FELLET, 2007). A OA é considerada um distúrbio articular mais comum, podendo afetar de $6 \%$ a $12 \%$ da população adulta e mais um terço das pessoas com mais de 65 anos de idade (FELLET; FELLET; FELLET, 2007). Porém, a doença não é sinônimo de envelhecimento, e está relacionada com a capacidade funcional.

Juntamente com o tecido ósseo, o tecido cartilaginoso compõe o esqueleto, sendo uma forma especializada de tecido conjuntivo de consistência rígida. Desempenha a função de suporte de tecidos moles, reveste superfícies articulares onde absorve choques e facilita deslizamentos (SHARMA et al., 2007).

Sua estrutura biológica é simples, composta de células chamadas condrócitos e uma matriz extracelular altamente especializada, sendo constituída de tecido avascular, nutrida pelos capilares do conjuntivo envolvente (pericôndrio) ou através do líquido sinovial das cavidades articulares. Essa falta de vascularização e a estrutura complexa fazem com que a cartilagem não se recupere quando lesada, sendo, portanto o alvo de engenharia tecidual (CHUNG; BURDICK, 2008).

A cartilagem articular é um tecido que, mesmo composto por um só tipo de célula, apresenta uma complexa estrutura interna, com características indispensáveis para sustentar sua função (ABHIJIT et al., 2008). Cobrindo as superfícies do osso na zona de contato articular, a cartilagem distribui a força 
de impacto, espalhando-se em uma área mais larga e então a transmite para o osso conseguindo lubrificar o movimento mesmo com grandes pressões aplicadas. Para ser capaz dessa atenuação, a mesma tem uma estratificação distinta: em cima, as fibras de colágeno estão orientadas paralelamente à superfície, usando as forças translaterais que ocorrem na fricção e na transmissão das forças de impacto para o lado. Essa transmissão, que continua na próxima camada intermediária é o que distribui a força em uma área mais ampla, evitando um impacto bruto em cima de uma pequena área. A estrutura das fibras colágenas esta formada por um tipo de "folha" de fibras que começa no osso com orientação vertical, continuando em um arco até o termino horizontal na superfície. Nessa zona, os GAG ficam mais densos com o aumento de profundidade, aumentando também o conteúdo de condroitin-6sulfato (C6S) em relação ao condroitin-4-sulfato (C4S). Isto influência a carga eletroquímica e a resistência ao movimento do líquido. As forças se comprimem cada vez mais, aumentam a pressão hidrostática até uma zona profunda, e então são transmitidas para o osso. A quarta zona, o contato ósseo-cartilagem, sendo a zona mineralizada, é de grande importância para o funcionamento da cartilagem e sua reconstituição. Ela garante que as forças não danifiquem o contato da cartilagem (mais mole) com o osso no maior momento de elasticidade (BUCKWALTER; MANKIN, 1998).

Reconstituir a transição mineralizada entre cartilagem e osso é indispensável para garantir a integração do implante e assegurar a junção ósseo-cartilagem, sendo essa uma das grandes tarefas ainda não concluídas para a substituição de cartilagem (BUCKWALTE; MANKIN, 1998).

A lesão da cartilagem articular apresenta um limitado potencial de reparo e alguns defeitos não cicatrizam espontaneamente. Quando a lesão acomete o osso subcondral, o processo de reparo é esporádico, sendo que a cartilagem articular original é substituída por fibrocartilagem e tecido cicatricial (HUANG et al., 2004).

O crescimento, reparo e remodelação dos ossos são provocados por fatores locais e sistemáticos. Os materiais biológicos osteoconstrutivos necessariamente têm que, junto com os fatores ambientais, serem capazes de estimular o crescimento e a mineralização do tecido do osso (WLODARSKI, 1991 apud MUZZARELLI et. al., 1993). Idealmente, eles são 
reabsorvidos pelo corpo no processo de remodelação do osso, na qual a estrutura mineral será absorvida por osteoclastos e reconstruída por osteoblastos (DETSCH et al., 2008).

Há basicamente duas etiologias diferentes descritas para um estágio avançado da OA: fatores sistemáticos (predisposição genética), como variáveis endógenas, e esforço biomecânico impróprio ou esquema simples e comum da sobrecarga (OTTE, 2000; FRITZ et al., 2008). De acordo com Fritz et al. (2008), a atividade física e os esportes, principalmente os de alto impacto como o futebol, o handball, basquete podem ser a causa de $49 \%$ dos defeitos na cartilagem.

Além das influências genéticas, a idade é o fator de risco principal para OA e diversos estudos mostraram que a capacidade de regeneração da cartilagem articular diminui de acordo com a idade causando a maioria dos problemas com a articulação do joelho. Alguns fatores de risco adicionais são o excesso de peso, determinadas desordens metabólicas, má nutrição, instabilidades comuns, junção-sobrecarga e ferimentos da cartilagem (OTTE, 2000 apud FRITZ et al., 2008). A articulação do joelho, além de caracterizarse como um dos principais sítios de acometimento da doença, também está relacionada a fatores de risco freqüentemente encontrados em populações de baixo nível socioeconômico (CIMMINO et al., 2005).

Os estudos revelam que entre todas as grandes junções, o joelho é predominante afetado por mudanças degenerativas, além de ser uma das articulações com maior acometimento de OA. Está presente em 6\% da população adulta acima de 30 anos e em pessoas com mais de 55 anos, sua prevalência aumenta para 10\% (SRIKANTH et al., 2005). Dependendo do método da pesquisa, os critérios da inclusão, da exclusão e o país de origem, os dados epidemiológicos mostram uma grande variação nos termos do estudo e da população (GAISSMAIE, 2006; FRITZ et al., 2008). Estudos realizados na Holanda com pessoas acima de 45 anos, revelaram incidência de artrose em $0,83 \%$ dos homens e 2,08\% das mulheres, comprovadas por análises radiológicas. Na Suécia a incidência foi de 0,9\% em pessoas entre 75 e 79 anos (FRITZ et al., 2008). Já em São Paulo, foi constatado a OA em $36 \%$ do total de 84 pacientes idosos, com idade igual ou superior a 60 anos. Destes pacientes, $70,9 \%$ eram do sexo feminino, sendo que a articulação 
mais acometida foi o joelho, com 29,7\% (de ROSIS; MASSABKI; KAIRALLA, 2010). Pesquisas utilizando artroscopia em joelhos nos Estados Unidos da América (EUA) revelaram alterações em cartilagem articular em 19\% dos casos avaliados, afetando predominantemente o côndilo femoral medial. Somente em $36 \%$ destes pacientes não foi diagnosticado outras patologias, tais como rupturas do ligamento ou lesões do menisco (CURL et al., 1997 apud FRITZ et al., 2008). Um estudo escandinavo realizando 1000 artroscopias consecutivas do joelho revelou lesão condral ou osteocondral em $61 \%$ de todos os pacientes analisados (HJELLE et al., 2002).

Em resumo, os dados epidemiológicos indicaram defeitos limitados dessa cartilagem da espessura completa ocorrem razoavelmente de maneira freqüente, mesmo em jovens. Desde que a cartilagem hialina não é inervada, os defeitos maiores podem permanecer completamente sem manifestação de sintomas por um tempo razoavelmente longo. Um defeito da cartilagem tornase freqüentemente visível na aparência de sintomas secundários (GAISSMAIE, 2006; FRITZ et al., 2008).

Os animais como coelhos, cachorros e ovelhas têm o processo de osteogênese similar ao de humanos, sendo considerado ideal para pesquisas de crescimento e remodelação óssea (HOLY et al., 2000). Por isso utilizamos o ovino como nosso modelo experimental para poder estudar a OA. 


\section{OBJETIVOS}

Nossos objetivos neste trabalho foram:

\subsection{OBJETIVOS GERAIS}

- Testar um novo modelo de terapia celular através do implante de células-tronco de polpa dentária humana, cultivadas ou não em associação com biomateriais em lesões ósseo-articulares femorotibiopatelar de ovino.

\subsection{OBJETIVOS ESPECÍFICOS}

- Cultivar as células-tronco de polpa dentária humana expressando o gene repórter EGFP;

- Cultivar as células-tronco de polpa dentária humana nos biomateriais e verificar a biocompatibilidade;

- Promover lesões ósseo-articulares em articulação femorotibiopatelar de ovinos para implantar as células-tronco de polpa dentária humanas nestas lesões;

- Avaliar clinicamente o efeito da terapia celular utilizando as células cultivadas em biomaterial comparando o efeito obtido também utilizando apenas as células ou apenas o biomaterial e sem tratamento. 


\section{MATERIAIS E MÉTODOS}

O projeto proposto foi conduzido após avaliação e aprovação pela Comissão de Bioética da Faculdade de Medicina Veterinária e Zootecnia da Universidade de São Paulo (FMVZ-USP).

Este projeto contou com uma colaboração internacional do FriedrichBaur-Forschungsinstitut für Biomaterilien/ Universitat Bayreuth e Biocer entwicklungs - $\mathrm{GMBH}$, na Alemanha, para o desenvolvimento e produção do biomaterial.

\subsection{CÉLULAS}

Células-tronco de polpa dentária humana (CTPD) obtidas de acordo com protocolo descrito em Kerkis et al., 2006 foram utilizadas neste projeto. Além disso, com objetivo de facilitar o monitoramento, estas células foram transduzidas com retrovírus recombinantes carregando o gene repórter, EGFP, pela Dra Patrícia C.B.Beltrão Braga.

As CTPDs transduzidas com EGFP foram cultivadas em meio de cultura Dulbecco's Modified Eagle's Medium (DMEM/F12 - Invitrogen, Aukland, New Zealand) contendo $15 \%$ de soro fetal bovino (SFB - Invitrogen), $1 \%$ de Penicilina/Estreptomicina (100 IU/mL /estreptomicina $100 \mu \mathrm{g} / \mathrm{mL}$ - LGC Biotecnologia, São Paulo, Brasil), 1\% de L-glutamina (Invitrogen) e 1\% de aminoácidos não essenciais (MEM NEAA - Invitrogen). Este meio foi chamado de DMEM completo (DMEMc). As células foram mantidas em estufa a $37^{\circ} \mathrm{C}$ com atmosfera úmida contendo $5 \%$ de gás carbônico $\left(\mathrm{CO}_{2}\right)$.

\subsection{BIOMATERIAL}

O desenvolvimento do biomaterial ideal e compatível com o nosso modelo animal ocorreu na Alemanha, pelo grupo de pesquisadores do 
Instituto Friedrich-Baur-Forschungsinstitut für Biomaterilien da Universitat Bayreuth e Biocer entwicklungs - GMBH, da Alemanha.

A estrutura do biomaterial para o reparo osteocondral foi feita utilizando implantes cerâmicos de hidroxiapatita (HA) comercial. Estes implantes foram otimizados para o crescimento e a formação óssea. O implante cartilaginoso foi associado com cerâmica, utilizando-se uma solução de sílica embebida em hidroxiapatita em pó. Esta técnica foi desenvolvida pelo Friedrich-BaurInstitute produzindo assim um material durável, reabsorvível e altamente biocompatível, unindo um implante cartilaginoso sólido e fornecendo substrato para a construção de osso subjacente. O material é poroso, o que permite a passagem de células, e também podemos dizer que mimetiza a zona de transição da cartilagem com a superfície óssea (HOFFMANN et al., 2009).

Já, o arcabouço cartilaginoso foi desenvolvido durante o primeiro ano de projeto, pelo grupo de pesquisadores da Alemanha, iniciando com esponjas estáveis liofilizadas de quitosana, o qual foi modificado pela adição de componentes da matriz cartilaginosa nativa como a hialurona, sulfatos de condroitina, sulfato de dermatana e colágeno II.

Os componentes foram selecionados de acordo com estudos preliminares de testes in vitro com condrócitos isolados de bovino e uma linhagem célular condrocíticas murinas ATDC5.

Outra modificação foi a construção de esponjas biocompatíveis de poliuretano, funcionalizados com polissacarídeos supramencionados combinando propriedades mecânicas com uma superfície biomecanicamente funcional (HOFFMANN et al., 2009).

\subsection{MODELO ANIMAL}

Os modelos animais são indispensáveis para o entendimento e sucesso no tratamento de muitas doenças. Sendo assim, utilizamos neste projeto, ovino sem raça definida (SRD), com idade entre 24 e 36 meses, castrados, pois possuem bons resultados com processos de regeneração óssea e também porque nosso grupo possui experiência com modelo de lesão óssea nesses animais. 
O animal foi mantido no Serviço de Cirurgia de Grandes Animais da FMVZ-USP em uma baia de 10 metros quadrados.

A alimentação desses animais foi feita à base de feno, duas vezes ao dia; $200 \mathrm{~g}$ de ração peletizada, uma vez ao dia e água a vontade. As condições de manejo foram mantidas durante todo o período experimental.

\subsection{PREPARO DAS CÉLULAS-TRONCO DE POLPA DENTÁRIA PARA IMPLANTAÇÃO NOS ANIMAIS ASSOCIADAS OU NÃO AO BIOMATERIAL}

Inicialmente, o biomaterial foi colocado sobre o poço de uma placa de 12 orifícios e embebido por aproximadamente 3 horas em meio de cultura para CTIPD, sendo o meio trocado a cada 30 minutos.

As CTPD humanas foram lavadas duas vezes com tampão salina fostato (PBS), tripsinizadas, homogeneizadas suavemente e centrifugadas a $1000 \mathrm{rpm}$ por 5 minutos. O precipitado celular obtido foi ressuspendido em DMEMc e submetido a contagem. Após a contagem das células, 1,5 × $10^{6}$ células foram ressuspendidas em $50 \mu \mathrm{l}$ de meio DMEM/F:12 sem soro e cuidadosamente aplicadas na superfície do biomaterial que contém a matriz cartilaginosa previamente preparada. Após 30 minutos, o meio DMEMc foi acrescentado em um volume suficiente para cobrir o biomaterial. A partir daí, foi colocado em uma incubação por 48 horas a $37^{\circ} \mathrm{C}$ em atmosfera úmida de $5 \%$ de $\mathrm{CO}_{2}$, antes do implante nos animais.

Já, a mesma quantidade de células foi semeada em uma placa de Petri de $10 \mathrm{~cm}$ para ser utilizada no procedimento cirúrgico sem associação com biomaterial.

Minutos antes de iniciar a cirurgia, as células no biomaterial ou na placa foram cuidadosamente lavadas com PBS por três vezes, para a eliminação do SFB utilizado no cultivo celular. Após as lavagens, as células da placa foram removidas com o auxílio de um rodo, centrifugadas e posteriormente ressuspendidas em $100 \mu \mathrm{l}$ de meio DMEM sem soro para o transporte. Já, os biomateriais associados ou não as células, após lavagens, foram recobertos com meio DMEM sem soro na placa, para o transporte. 


\subsection{ANÁLISE DA ADESÃO DAS CÉLULAS AO BIOMATERIAL}

Com o objetivo de analisar o potencial de adesão das células ao biomaterial, o mesmo procedimento acima foi realizado.

Para tanto, as células foram lavadas, tripsinizadas e, aproximadamente $1 \times 10^{6}$ CTIPD foram colocadas no biomaterial previamente tratado com meio de cultivo e acomodados em placa de 12 orifícios. As células foram mantidas durante 24 horas ou um mês. Além disso, um biomaterial foi deixado só com meio de cultura durante 24 horas e outro mantido durante um mês, sem presença de células, para também ser analisado. Vale lembrar que a troca do meio de cultura foi realizada a cada três dias.

\subsubsection{Análise do porcentual de adesão das CTPD ao biomaterial por contagem de células}

Visando obter uma porcentagem de células aderidas ao biomaterial, realizamos a contagem das células que sobraram no orifício da placa. Isso foi feito vinte e quatro horas após a colocação das células no biomaterial, quando então o mesmo foi retirado e submetido a procedimentos histológicos. As células que estavam aderidas sobre a placa onde 0 biomaterial foi acomodado foram lavadas com PBS, tripsinizadas e submetidas a contagem em câmara de Newbauer.

\subsubsection{Análise histológica do biomaterial associado ou não as CTPD}

Após 24 horas ou um mês do plaqueamento celular, o biomaterial foi submetido a procedimentos de rotina histológica. Biomaterial sem células também foram mantidos em meio de cultivo e foram submetidos aos mesmos procedimentos histológicos descritos no item 4.8 . 


\subsubsection{Análise por microscopia eletrônica de varredura (MEV) do biomaterial associado ou não a CTPD}

A MEV foi realizada em colaboração com a Dra. Rose Eli Grassi Rici do Departamento de Cirurgia, Setor de Anatomia da FMVZ-USP.

Neste experimento, novamente as células foram colocadas no biomaterial e cultivadas em placas de Petri de $3 \mathrm{~cm}$ de diâmetro. 0 biomaterial sem células também foi submetido a este processo. Em seguida, o meio de cultivo foi retirado e uma lavagem com PBS foi realizada para posterior fixação com glutaraldeído (3\%). Após 2 horas, o fixador foi retirado e as placas contendo os biomateriais foram lavadas em água destilada e pósfixadas em tetróxido de ósmio 1\% por 1 hora, seguida de lavagens em água destilada e série crescente de álcoois (50\% a 100\%). As placas com o cultivo celular e o biomaterial foram secas em estufa $37^{\circ}$. Na seqüência, foram submetidas a um revestimento metálico sputting com ouro no aparelho metalizador EMITECH K550, sendo analisadas e fotografadas em microscópio eletrônico de varredura (LEO 435VP - Zeiss, Germany).

\subsection{PROCEDIMENTO CIRÚRGICO DE IMPLANTAÇÃO DAS CÉLULAS ASSOCIADAS OU NÃO AO BIOMATERIAL}

O material foi implantado na cartilagem da articulação femorotibiopatelar, através de procedimento cirúrgico, onde quatro lesões foram realizadas. A primeira recebeu a injeção apenas de CTPD, a segunda, biomaterial, a terceira CTPD humana associadas ao biomaterial e, por último, o controle, que não recebeu nenhum tratamento para a lesão.

O animal está completando um ano em observação e após esse período, de acordo com o protocolo aprovado pelo comitê de ética da FMVZUSP, ele será eutanasiado para posteriores análises histológicas. 


\subsubsection{Protocolo Anestésico}

Como pré-medicação foi utilizado $0,6 \mathrm{mg} / \mathrm{kg}$ de maleato de midazolam (Genon, São Paulo, Brasil) associado a $2 \mathrm{mg} / \mathrm{kg}$ de cloridrato de meperidina (Genon, São Paulo, Brasil) na mesma seringa por via intravenosa (IV). Assim que o animal veio a decúbito ventral foi realizada a tricotomia da articulação femorotibiopatelar e da veia cefálica, para acesso venoso. Para a fluidoterapia utilizou-se ringer lactato (J. P. indústria farmacêutica, São Paulo, Brasil) durante todo o período trans-operatório.

$\mathrm{O}$ animal foi induzido anestesicamente com $3,5 \mathrm{mg} / \mathrm{kg}$ de propofol (Propofol $^{\circledR}$, Eurofarma, São Paulo, Brasil) associado a $5 \mu \mathrm{g} / \mathrm{kg}$ de cloridrato de fentanil (Fentani ${ }^{\circledR}$, Cristália, São Paulo, Brasil). Em seguida, o animal foi intubado com sonda endotraqueal (Rüschelit ${ }^{\circledR}$, Kernen, Germany) de tamanho apropriado e mantido em anestesia com isofluorano (Isoran ${ }^{\circledR}$, Biochimico, Rio de Janeiro, Brasil) diluído em oxigênio 100\%.

\subsubsection{Procedimento Cirúrgico}

Para a realização da cirurgia, o animal permaneceu em jejum hídrico de 12 horas e sólido por um período de 24 horas. Em seguida a articulação femorotibiopatelar esquerda foi tricotomizada e deixada na posição lateral para poder realizar o procedimento (Figura 1A). A pele foi incisada como de rotina, divulsionando tecidos para dar acesso aos músculos e a região óssea.

A técnica estéril de artrotomia parapatelar medial foi realizada e logo após a visualização da patela, a mesma foi deslocada lateralmente através de pressão manual e o membro do animal foi flexionado para melhor visualização dos côndilos femoral medial e lateral (Figuras 1B).

Com o auxílio de um punch (Kolplacir, São Paulo, Brasil) para biópsia de pele de $5 \mathrm{~mm}$ foram delimitados os quatros defeitos osteocondrais, sendo dois na porção proximal do sulco femoral e outros dois na parte distal (Figuras $1 \mathrm{C}$ e D). A cartilagem foi removida com lâmina de bisturi número 15 
(two arrows, Shanghai, China). Para finalizar, os defeitos subcondrais de 6 $\mathrm{mm}$ de profundidade foram criados com auxílio de furadeira e broca cirúrgica de 4,5 mm em baixa rotação (Figura 1E). A profundidade dos defeitos ósseos foi verificada com medidor de profundidade cortical com 0 intuito de padronizar os defeitos osteocondrais criados.

Os defeitos subcondrais criados desta maneira foram limpos e irrigados abundantemente com solução salina estéril. A cápsula articular, o tecido subcutâneo e a pele foram fechados com suturas de rotina. A cápsula articular foi suturada em pontos simples separados com Vycril 2-0 (Brasuture, São Paulo, Brasil) e a pele com pontos Nylon 2-0 (brasuture, São Paulo, Brasil) em pontos simples separados.

Neste momento, $20 \mathrm{mg} / \mathrm{kg}$ de cefalotina sódica (Kefalomax ${ }^{\circledR}$, Biochemical $^{\circledR}$, Rio de Janeiro, Brasil) por via intramuscular profunda foi utilizado duas vezes ao dia, por 7 dias para profilaxia antibacteriana.

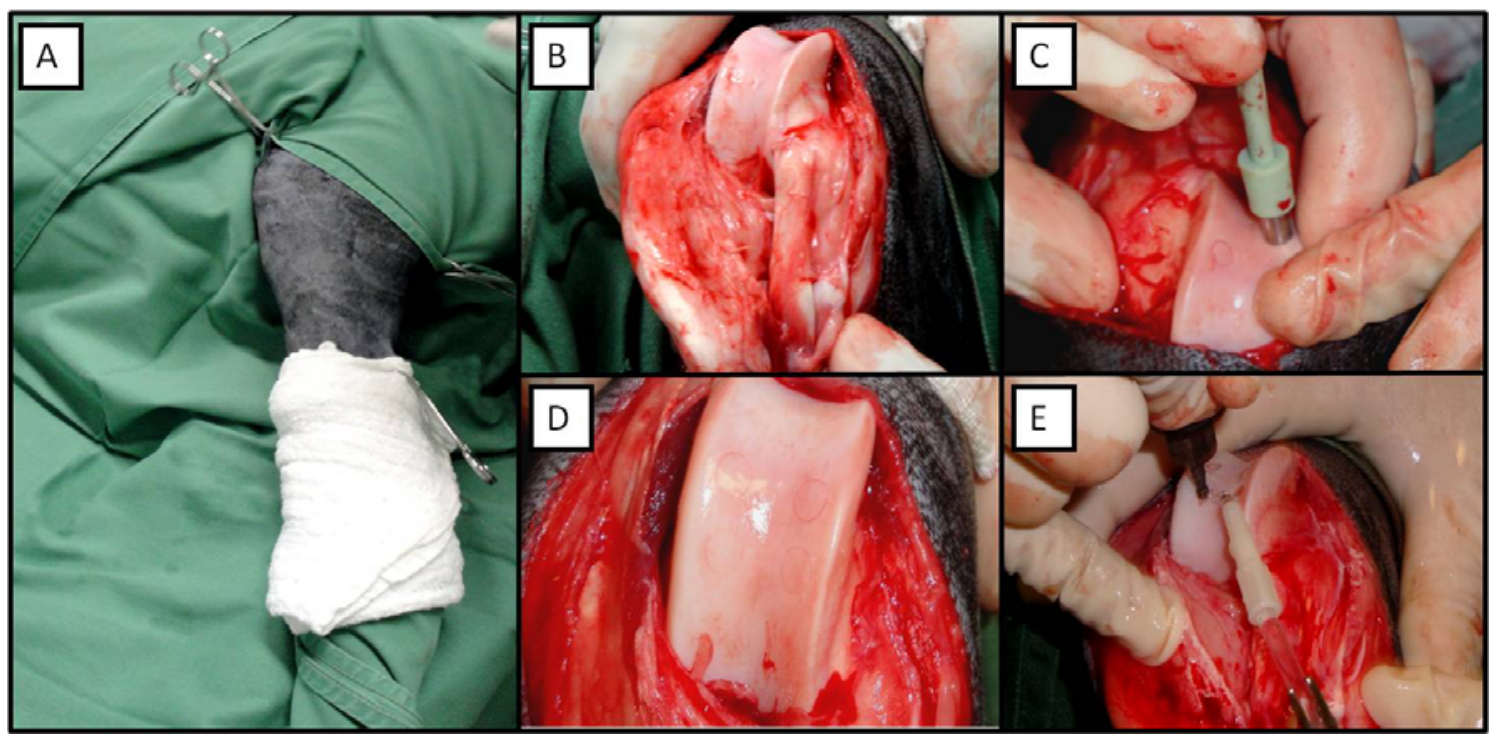

Figura 1 - Imagens macroscópicas do procedimento cirúrgico na articulação femorotibiopatelar esquerda de ovino. A) Articulação femorotibiopatelar de ovino com vista lateral, na qual foi feita a tricotomia do local; B) Visualização do fêmur do animal. C) Punch para biópsia de pele de $5 \mathrm{~mm}$ delimitando os defeitos subcondrais no fêmur. D) Marcações dos quatro orifícios no fêmur obtidas após delimitação com punch. E) Procedimento de obtenção dos dois defeitos subcondrais na porção proximal e os outros dois na porção distal do fêmur utilizando furadeira. Imagens obtidas através de uma máquina fotográfica 


\subsubsection{Cuidados Pós-Cirúrgicos}

Para analgesia imediata, após o procedimento cirúrgico, o animal recebeu $1 \mathrm{mg} / \mathrm{kg}$ de cetoprofeno (Ketofen ${ }^{\circledR}$, Merial, São Paulo, Brasil), 25 mg/kg de dipirona sódica (D-500 ${ }^{\circledR}$, Fort Dodge Saúde Animal, São Paulo, Brasil) e 2 mg/kg de cloridrato de tramadol (Tramal ${ }^{\circledR}$, Pfizer, São Paulo, Brasil) por via IV. A analgesia foi mantida duas vezes ao dia com cloridrato de tramadol 2mg/kg (Tramal ${ }^{\circledR}$, Pfizer, São Paulo, Brasil) e dipirona sódica (D$500^{\circledR}$, Fort Dodge Saúde Animal, São Paulo, Brasil) por cinco dias.

A profilaxia antibacteriana foi feita através de enrofloxacina (Baytril ${ }^{\circledR}$, Bayer, São Paulo, Brasil) na dose de $5 \mathrm{mg} / \mathrm{Kg}$ uma vez ao dia, durante cinco dias após a realização do procedimento cirúrgico.

Logo após a cirurgia, foi aplicada bolsa de gelo por 25 a 30 minutos na articulação femorotibiopatelar do animal, promovendo desta forma analgesia adicional e diminuição do edema. Nas demais semanas foi aplicada bolsa de água quente por 15 minutos no mesmo local para auxiliar na recuperação do animal e o animal vem sendo mantido em baias individuais até o momento.

\subsection{MONITORAMENTO CLÍNICO DOS ANIMAIS TRATADOS COM BIOMATERIAIS ASSOCIADOS OU NÃO AS CTPD HUMANAS}

Visando monitorar a evolução clínica dos animais tratados, realizamos os seguintes exames diagnósticos: radiografia, ultrassonografia e artroscopia.

\subsubsection{Exame Radiográfico}

Todos os procedimentos radiográficos utilizados foram realizados no setor de radiologia do Hospital Veterinário (HOVET) da FMVZ-USP com auxílio da médica veterinária Silvana Maria Unruh.

Neste procedimento foi utilizado aparelhos radiográficos Tecnodesign $^{\circledR}$ e Ray-Tec ${ }^{\circledR}$ de 100 a 500 miliampéres (mA) para a captura das 
imagens em um sistema digital computadorizado Fuji FCR CAPSULA $X^{\circledR}$. Para melhor diagnóstico, foram feitas as projeções: mediolateral e craniocaudal da articulação femorotibiopatelar (membros direito e esquerdo) com o animal em decúbito lateral.

\subsubsection{Exame Ultrassonográfico}

Os exames ultrassonográficos foram realizados no setor de Serviço de Cirurgia de Grandes Animais da FMVZ-USP e no setor de ultrassonografia do Hospital Veterinário (HOVET) da FMVZ-USP com a colaboração da equipe do Prof. Dr. Stefano Carlo Filipoo Hagen.

O animal foi contido manualmente em decúbito lateral para a realização do exame e a pele na região a ser examinada foi tricotomizada com tosquiadeira Oister $^{\circledR}$, lâmina 40 e lavada em seguida com água e sabão. $O$ gel acústico foi aplicado sobre a superfície. Movimentos passivos de flexão e extensão da articulação foram realizados durante a avaliação.

Para este procedimento, o aparelho ultrassonográfico My Lab 30 esaote $^{\circledast}$ (Esaote, Genova, Itália) com transdutor linear de $8-12 \mathrm{MHz}$ e microconvexo de $5-8 \mathrm{MHz}$ foi utilizado. Convém ressaltar, que após 87 dias do procedimento cirúrgico foi utilizado um outro equipamento, o ATDL 4000 com transdutor linear $10-12 \mathrm{MHz}$.

A articulação femorotibiopatelar foi avaliada completamente a cada exame, com atenção especial aos côndilos femorais, dos quais imagens transversais e longitudinais foram adquiridas.

\subsubsection{Exame de Artroscopia}

A artroscopia é uma técnica minimamente invasiva, que permite tanto o diagnóstico como a intervenção cirúrgica articular, fornecendo assim uma ampla inspeção da cavidade articular e de sua superfície. Esse procedimento visa analisar a reparação dos defeitos osteocondrais em diferentes momentos. 
Os procedimentos artroscópicos foram realizados no Serviço de Cirurgia de Grandes Animais do Departamento de Cirurgia da FMVZ-USP com a colaboração da equipe do Prof. Dr. Luiz Claudio Lopes Correia da Silva.

O animal foi pré-medicado e anestesiado de acordo com o protocolo descrito no item 4.6.1.

O animal foi posicionado em decúbito dorsal para a realização do procedimento de artroscopia, mediante prévia tricotomia, anti-sepsia e montagem de campo operatório na região femorotibiopatelar como de rotina para procedimento cirúrgico (Figura $2 \mathrm{~A}$ ).

O procedimento iniciou-se com punção articular e tentativa de retirada de líquido sinovial, utilizando agulha $40 \times 10$ (BD) e seringa de $20 \mathrm{ml}$, porém em nenhum dos procedimentos conseguiu-se quantidade satisfatória de líquido para posteriores análises.

Com isso, utilizando-se a mesma agulha, $35 \mathrm{ml}$ de solução eletrolítica balanceada e estéril foram infundidos, para proporcionar distensão da cápsula articular e facilitar a confecção do primeiro portal para inserção do artroscópio. Após incisão puntiforme de pele, tecido subcutâneo e cápsula articular com lâmina de bisturi $n^{\circ} 11$, a cânula artroscópica e o obturador cônico em posição crânio-lateral infrapatelar foram introduzidos. Em seguida, substituiu-se o obturador pela ótica de $4,0 \mathrm{~mm}$ a $30^{\circ}$ iniciando-se o exame da articulação.

Após inspeção da cavidade articular, e visualização das estruturas anatômicas de interesse (cristas e sulco trocleares), identificou-se o melhor posicionamento da ótica para captura de imagens.

Para realização das imagens foi utilizado um aparelho de artroscopia com fonte de luz da marca STORZ $^{\circledR}$ modelo Nova e uma microcâmera modelo DX ntsc (Karl Storz GmbH \& Co. KG, Tuttlinglen, Alemanha).

A solução eletrolítica foi infundida continuamente para a cavidade articular por sistema pressurizado, sem controle de pressão máxima, para manutenção da distensão articular durante todo o procedimento cirúrgico, através da válvula da cânula artroscópica, sendo o volume excedente drenado através da agulha previamente posicionada (Figura 2B).

A pele do animal após o procedimento foi suturada em pontos simples separados, utilizando náilon 2-0 e a recuperação anestésica ocorreu em baia 
silenciosa e escura após o término do procedimento cirúrgico, provido de analgésico pós-operatório.
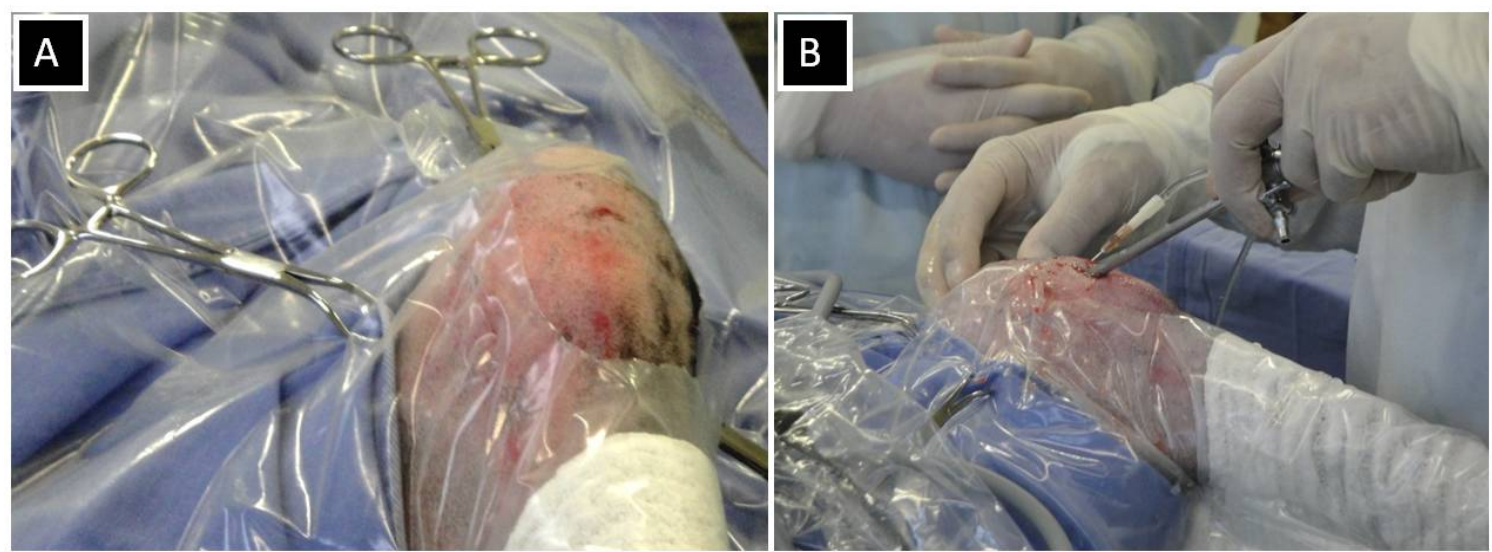

Figura 2 - Imagem do procedimento de artroscopia na articulação femorotibiapatelar do ovino submetido ao tratamento com biomaterial associado ou não a CTPD. A) Preparo do campo operatório na articulação femorotibiopatelar esquerda do animal, após antisepsia. B) Introdução da cânula artroscópica na articulação

\subsubsection{Exames bioquímicos e hemograma}

Para a realização destes exames, o animal foi devidamente contido e através da punção da veia jugular e colheu-se aproximadamente $10 \mathrm{~mL}$ de sangue. $\mathrm{O}$ sangue coletado foi divididos em 2 tubos $\left(\right.$ Vacuntainer ${ }^{\circledR}$, Becton Dickinson, New Jersey, USA), um contendo anticoagulante ácido etileno diaminotetracético (EDTA) a 7,5 \% para a realização de hemograma e outro de vidro siliconizado contendo gel separador de soro. Neste caso, o material foi centrifugado a 3000 rpm durante 10 minutos para obtenção do plasma sanguíneo para a realização das análises bioquímicas.

A contagem de hemácias, leucócitos e plaquetas foi realizada utilizando o Contador hematológico modelo ABX Vet (Horiba ${ }^{\circledR}$, Kyoto, Japão).

As análises bioquímicas foram realizadas no equipamento Liasys ${ }^{\circledR}$ (Roche, São Paulo, Brasil) utilizando kits comerciais. Essas análises envolveram as determinações das concentrações séricas de ureia, creatinina, alanina aminotransferase (ALT), aspartato aminotransferase (AST), fosfatase alcalina (FA), creatina quinase (CK), gama-glutamil transferase (GGT), 
proteína total, albumina, cálcio, fósforo, sódio, potássio e colesterol, albumina (ALB), bilirrubina direta e indireta (BID).

Os resultados dos exames demonstrados neste projeto foram obtidos a partir coleta de sangue realizada minutos antes do procedimento cirúrgico e após duas semanas do procedimento.

\subsection{ANÁLISE HISTOLÓGICA DA ARTICULAÇÃO FEMOROTIBIOPATELAR DOS OVINOS SUBMETIDOS AO TRATAMENTO COM BIOMATERIAL ASSOCIADO OU NÃO A CTPD}

Para comprovar o potencial da terapia celular e do uso de biomaterial na reconstituição da cartilagem da fossa troclear em ovinos, o local onde foi submetido ao tratamento serão coletados e submetidos a análise histológica.

Como o procedimento de descalcificação óssea é um dos fatores limitantes neste trabalho, submetemos fragmentos do articulação femorotibiopatelar não tratados com o biomaterial a diferentes processos de descalcificação óssea bem como, ao metilmetacrilato e rotinas histológicas. Isso foi feito com objetivo de achar o melhor método de análise do material uma vez que o primeiro procedimento o qual havíamos pensado não se mostrou tão satisfatório em um primeiro momento.

\subsubsection{Descalcificação Óssea}

A descalcificação óssea da articulação femorotibiopatelar do ovino é um procedimento muito importante para as futuras análises do material. Para tanto, a articulação femorotibiopatelar de ovinos obtidos através de doação de animais de descarte, foram divididas em quatro partes iguais seguindo o raciocínio do local onde será inserido o biomaterial associado ou não a CTPD. Após essa divisão os fragmentos foram colocados em potes, fixados e submetidos aos seguintes métodos de descalcificação: 


\subsubsection{Descalcificação com Ácido Etílico Tetra-Acético (EDTA)}

Neste caso, o procedimento de descalcificação foi realizado após a fixação dos fragmentos contendo os orifícios cirúrgicos em solução de Bouin por 48 horas e posteriormente, lavados em água corrente por aproximadamente 30 minutos.

A descalcificação foi realizada a partir da imersão dos fragmentos em solução de EDTA 10 \% (Invitrogen) em água em quantidade três vezes maior do que o seu volume (Figura $3 \mathrm{~A}$ e $\mathrm{B}$ ).

As amostras ficaram em observação por seis meses sendo a solução trocada a cada dois dias até a descalcificação total do material. Para verificar a descalcificação $5 \mathrm{ml}$ da solução, na qual os fragmentos estavam imersos, foram retiradas e nela adicionamos $1 \mathrm{ml}$ de oxalato de amônio a $5 \%$.

Completado o procedimento de descalcificação, as amostras foram lavadas em água destilada, desidratadas em séries crescentes de alcoóis (70\%, 80\%, 90\% e 100\%), diafanizadas em xilol e incluídas em parafina a $65^{\circ} \mathrm{C}$ formando os blocos. Desses foram obtidos alguns cortes histológicos com $5 \mu \mathrm{m}$ de espessura originando lâminas histológicas.

\subsubsection{Descalcificação com Solução de Morse}

Da mesma maneira que o procedimento acima os fragmentos coletados foram fixados em solução de Bouin por 48 horas e posteriormente lavados em água corrente por aproximadamente 30 minutos.

Para descalcificação, as amostras foram imersas em solução três vezes maior do que o seu volume em solução de Morse composta por ácido fórmico a $50 \%$ e citrato de sódio a $20 \%$ durante 6 meses sendo a mesma trocada a cada dois dias (Figura 3C). Para verificar a descalcificação $5 \mathrm{ml}$ da solução, na qual os fragmentos estavam imersos, foram retiradas e nela 
adicionamos $1 \mathrm{ml}$ de oxalato de amônio a $5 \%$.

Ao final, as amostras foram lavadas em água destilada, desidratadas em séries crescentes de alcoóis (70\%, 80\%, 90\% e 100\%), diafanizadas em xilol e incluídas em parafina a $65^{\circ} \mathrm{C}$ formando os blocos. Desses foram obtidos alguns cortes histológicos com $5 \mu \mathrm{m}$ de espessura originando lâminas histológicas.
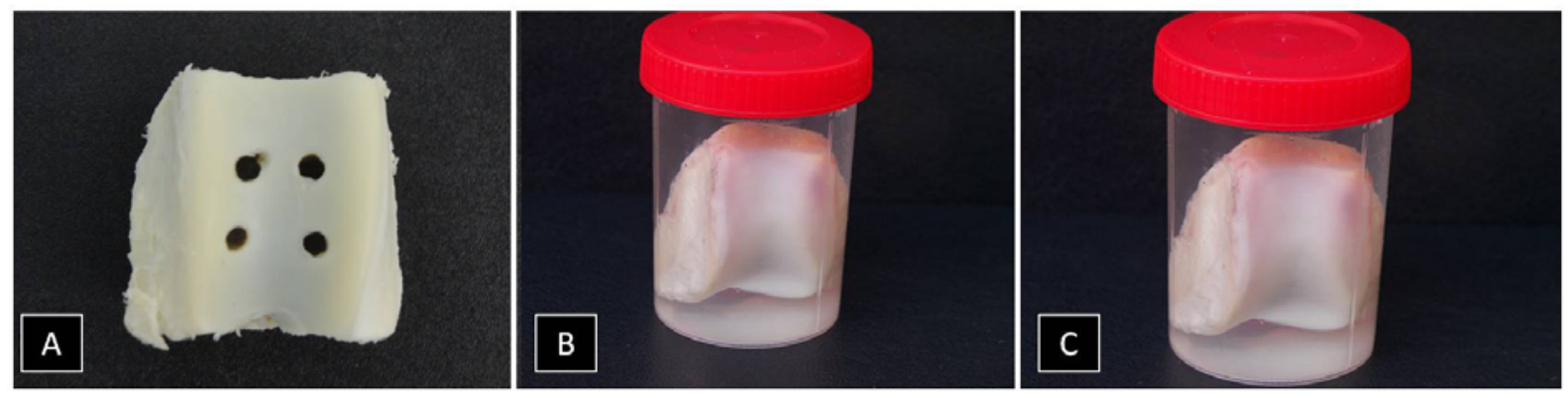

Figura 3 - Superfície do fêmur submetido a descalcificação. A) Fêmur com os quatro orifícios para serem descalcificados; B) Fragmento submetido a descalcificação em solução de EDTA $10 \%$ em água $C$ ) solução de Morse

\subsubsection{Descalcificação utilizando o descalcificador rápido (Safe Controllable Decalcifier Gold - RDO)}

Neste caso, a articulação femorotibiopatelar do animal foi dividida em quatro partes iguais sem os furos do procedimento cirúrgico (Figura 4A), colocados em potes e fixados em paraformaldeído a $5 \%$ por 24 horas. Em seguida, o paraformaldeído foi removido e o descalcificador rápido (RDO, Apex Enginering Products Co, Illinois, USA) foi adicionado (Figura 4B). O mesmo foi trocado diariamente até que as amostras encontrassem descalcificadas. Semanalmente foi feita a análise da descalcificação óssea utilizando uma agulha. Quando a mesma atravessava o material sem resistência, o osso era considerado adequado para poder fazer as lâminas para análises histológicas. Convém ressaltar, que quanto mais o fragmento estivesse descalcificado mais escura ficava a solução. 


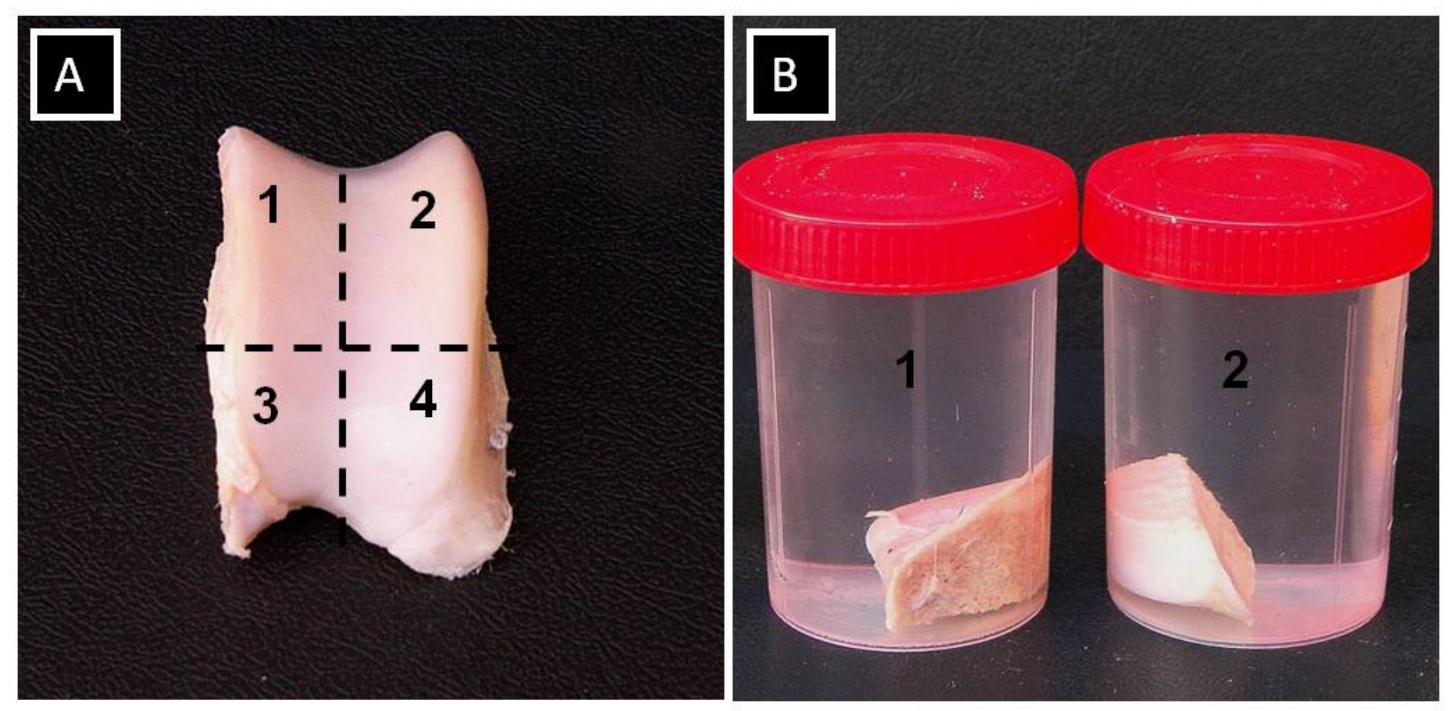

Figura 4 - Superfície do fêmur submetido a descalcificação utilizando descalcificador rápido (RDO). A) Marcações utilizadas para divisão dos 4 fragmentos. B) Amostra dos fragmentos submetidas a solução de $\operatorname{RDO}(1,2)$

\subsubsection{Procedimentos histológicos para a análise do material submetido ao processo de descalcificação}

Os procedimentos histológicos foram realizados de acordo com os protocolos descritos e estabelecidos por Tolosa et al. (2003).

Após a descalcificação total do material os fragmentos foram desidratados em séries crescentes de etanóis (70\% a 100\%) por uma hora cada. A etapa de diafanização foi feita com duas imersões em xilol por 1 hora cada um, para inclusão em parafina líquida a $60^{\circ} \mathrm{C}$ (Histosec - Merck Chemicals $^{\circledR}$, Darmstadt, Alemanha) por 12 horas, confeccionando-se blocos retangulares com base de $3 \times 4 \mathrm{~cm}$.

Após o a inclusão do material na parafina, os blocos contendo as amostras foram cortados em micrótomo automático Leica RM2165 (Leica, Wetzear, Alemanha) produzindo cortes de aproximadamente $5 \mu \mathrm{m}$. Os cortes obtidos foram devidamente assentados em lâminas histológicas e deixados na estufa a $60^{\circ} \mathrm{C}$ durante 2 horas para melhor adesão à lâmina.

Em seguida, as lâminas foram coradas com hematoxilina-eosina (HE) para análise estrutural do tecido cartilaginoso, picrosírius para marcação do 
colágeno, azo-carmin para análise estrutural e determinação de fibras colágenas e safranina para visualização do tecido cartilaginoso.

As lâminas após procedimentos de coloração foram montadas com Permount $^{\circledR}$ (Fischer Scientific, Pittsburgh, USA) e, posteriormente fotomicrografadas em microscópio Olympus BX 60 acoplado a câmera Axio CAM HRc.

\subsubsection{Colorações}

Neste projeto realizamos as seguintes colorações:

\subsection{Hematoxilina-Eosina}

Os cortes obtidos foram mergulhados no xilol por 10 minutos, cada passagem e em seguida, desidratados em séries crescentes de alcoóis $(70 \%$, $80 \%, 90 \%$ e $100 \%$ ). Após lavagem em água corrente por 10 minutos os materiais foram corados com hematoxilina (Merck Chemicals ${ }^{\circledR}$, Darmstadt, Alemanha) por 5 minutos e o material foi lavado em água corrente por 10 minutos para a retirada do excesso de hematoxilina. Logo em seguida, o material foi corado pela eosina (Merck Chemicals ${ }^{\circledR}$, Darmstadt, Alemanha) por 1 minuto e lavado com água por 30 segundos. Para finalização, o material corado foi submetido a uma série de alcoóis de 95\%, uma vez e duas vezes álcool $100 \%$, por 2 minutos cada e em série de xilóis (I, II, III) por três minutos cada.

O material obtido foi montando em solução de Permount (Fischer Scientific, Pittsburgh, USA) e analisado através de microscopia de luz no microscópio Olympus BX 60 acoplado a câmera Axio CAM HRc. 


\subsection{Coloração de Picrosírius}

Novamente os cortes obtidos foram mergulhados no xilol por 5 minutos, cada passagem e posteriormente, desidratados em séries crescentes de alcoóis $(70 \%, 80 \%, 90 \%$ e 100\%). Em seguida os cortes foram lavados em água por 30 segundos, corados com picrosírus por 40 minutos e submetidos a uma série crescente de alcoóis (70\%, 90\% e 100\%) por 5 minutos cada e em série de xilóis (I, II, III) por 5 minutos cada.

Após coloração, o material foi analisado por microscopia de luz utilizando microscópio Olympus BX 60 acoplado a câmera Axio CAM HRc.

\subsection{Coloração de azo-carmin}

O material analisado foi mergulhado no xilol (I, II) por 10 minutos, cada passagem. Em seguida, foi desidratado em séries crescentes de alcoóis (70\%, 80\%, 90\% e 100\%), lavado com água corrente por 10 minutos e corado com azo-carmin por 30 minutos. Para retirada do excesso do corante, o material foi lavado em água corrente por 10 minutos e também mergulhado no ácido fosfotuguístico pelo mesmo tempo. Na sequência o material foi corado pelo azul de anilina por 10 minutos seguidos de lavagem em água por 30 segundos. Em seguida o material foi submetido a uma série de alcoóis $(70 \%$, $90 \%$ e 100\%) por 5 minutos cada e em série de xilóis (I, II, III) por 5 minutos cada.

Após coloração as lâminas foram montadas e analisadas em microscopia de luz.

\subsection{Coloração de Safranina}

O material analisado foi mergulhado no xilol (I, II) por 7 minutos cada passagem. Em seguida, foi desidratado em séries crescentes de alcoóis (70\%, $80 \%, 90 \%$ e 100\%), lavado em água por 30 segundos e corado com 
safranina por 2 minutos. Para retirar o excesso do corante, o material foi lavado em água por 3 minutos. Depois, passou por uma série de alcoóis (70\%, 90\% e duas vezes 100\%) por 2 minutos cada e em série de xilóis (I, II, III) por 3 minutos cada.

Ao final, o material corado foi submetido à montagem e analisado em microscopia de luz.

\subsubsection{Inclusão da articulação femorotibiopatelar em Metilmetacrilato (MMA)}

Visando substituir o procedimento de descalcificação, a articulação femorotibiopatelar do animal foi seccionada em quatro partes iguais como nos procedimentos de descalcificação (Figura 5A). Em seguida, o material foi submetidos a série de alcoóis. As duas primeiras séries foram de $70 \%$ e 95\% durante dois dias a $4^{\circ} \mathrm{C}$ e as outras de $100 \%$, deixando por um dia. Posteriormente, o álcool a $100 \%$ foi substituído por um novo e deixado por mais dois dias a $4^{\circ} \mathrm{C}$. Finalizada essas séries de alcoóis, as amostras foram submetidas à xilol puro durante 18 horas a $4{ }^{\circ} \mathrm{C}$. Logo em seguida, começou o procedimento de inclusão das amostras no metilmetacrilato (Figura 5B). Para tanto o material foi submetido à solução I $\left(75 \mathrm{~mL}\right.$ de metilmetacrilato (Vetec ${ }^{\circledR}$, Rio de Janeiro, Brasil) e $25 \mathrm{~mL}$ dibutilftalato (Vetec ${ }^{\circledR}$, Rio de Janeiro, Brasil) durante dois dias a $4^{\circ} \mathrm{C}$. Passado este tempo, o material foi retirado e adicionou-se a solução II (75 mL metilmetacrilato, $25 \mathrm{~mL}$ dibutilftalato e $1 \mathrm{~g}$ de peróxido de benzoíla $\left(\operatorname{Vetec}^{\circledR}\right.$, Rio de Janeiro, Brasil). Após dois dias de incubação a $4{ }^{\circ} \mathrm{C}$ adicionamos a solução III $(75 \mathrm{~mL}$ metilmetacrilato, $25 \mathrm{~mL}$ de dibutilftalato e $2,5 \mathrm{~g}$ de peróxido de benzoíla) por dois dias em estufa a 39$41^{\circ} \mathrm{C}$.

Ao final, as amostras foram retiradas dos devidos potes, reduzidas de tamanho mediante o processo de polimento através da politriz e lixadeira poli plan (PANTEC, Panambra, São Paulo, Brasil), e submetidas a cortes em micrótomo de alto impacto, EXAKT BAN SYSTEM 300 CP (EXAKY Technologies, Apparatebau GMBH \& Co, Germany) com o auxílio da equipe 
da Profa. Dra. Sílvia Boldrin. Os cortes obtidos foram submetidos às colorações como descrito no item 4.8.2.1 e analisados por microscopia de luz.

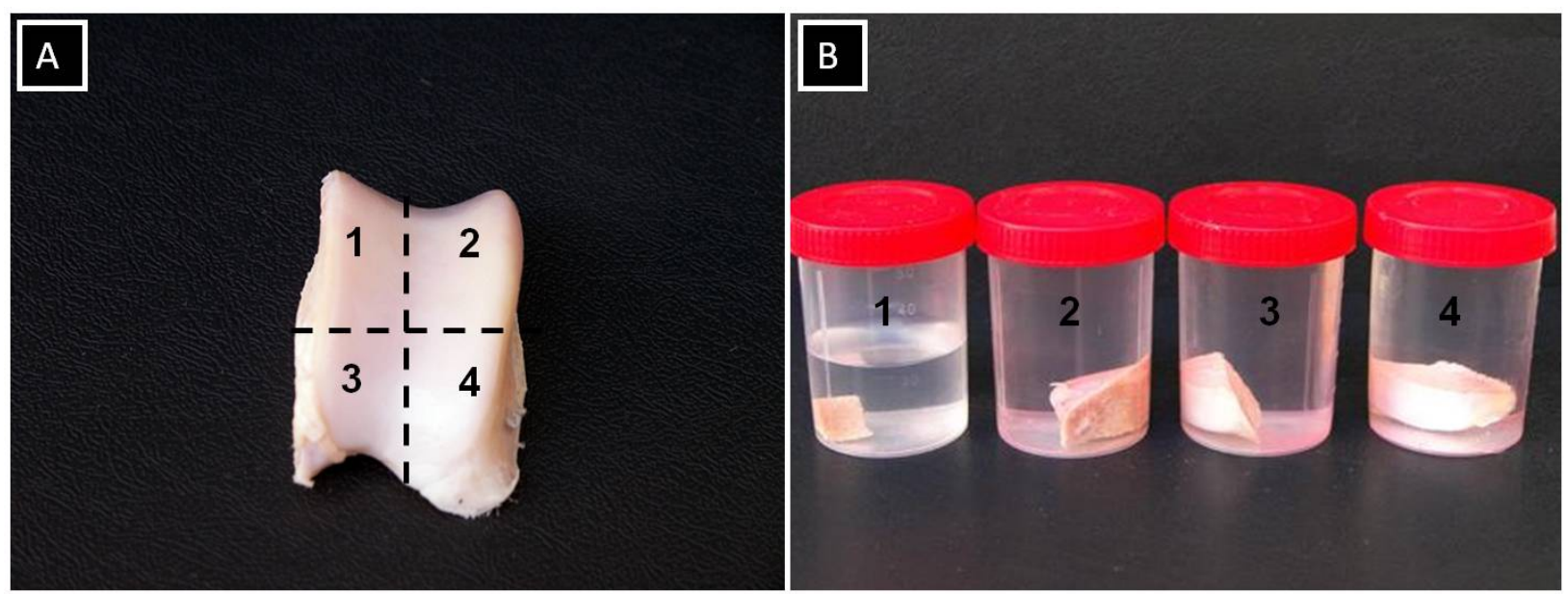

Figura 5 - Superfície do fêmur dividido em quatro partes e incluído no MMA. A) Fêmur com as quatro delimitações; B) Amostras incluídas na solução de MMA 


\section{RESULTADOS}

Os resultados encontrados foram descritos em tópicos de acordo com a metodologia utilizada.

\subsection{CÉLULAS-TRONCO DE POLPA DENTÁRIA HUMANA}

A figura 6 mostra a morfologia das CTPD humana apresentando característica fibroblastóides alongadas, fusiformes, pontiagudas, com núcleo grande e central.

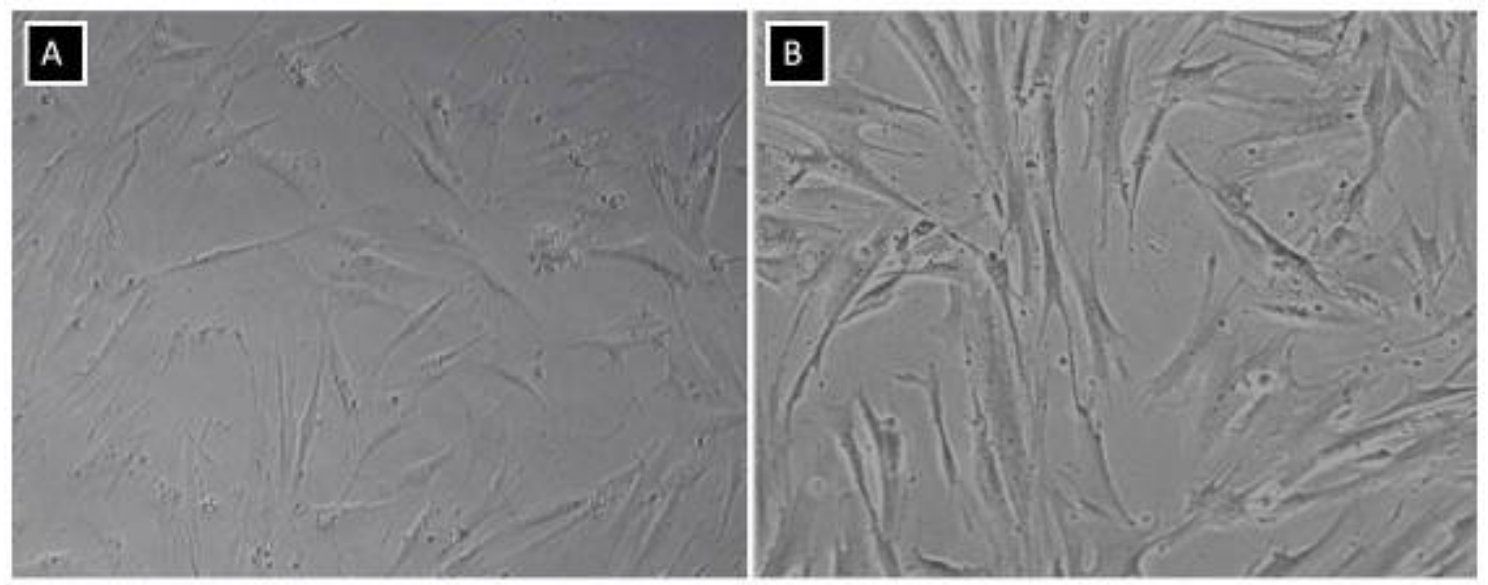

Figura 6 - Fotomicrografia mostrando a morfologia CTPD humana por microscopia óptica. A) Aumento de 40x B) 100x

Como já mencionado anteriormente no item materiais e métodos, as CTPD foram transduzidas com vetores virais carregando o gene repórter EGFP, com o objetivo de facilitar o monitoramento das células. Observe na figura 7 que a morfologia das CTPD não foi alterada após a transdução com o gene repórter e que as mesmas estão expressando este gene quando visualizada por microscopia de fluorescência. Observe que os núcleos das células foram corados em azul com DAPI. 


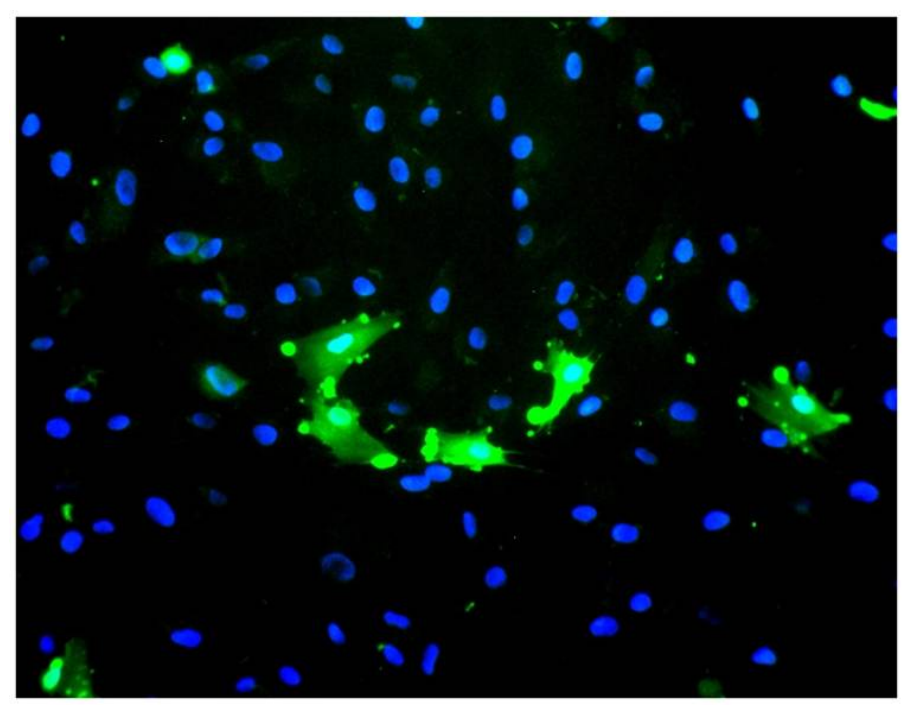

Figura 7 - Fotomicrografia das CTPD humana transduzidas com retrovírus carregando gene EGFP por microscopia óptica de fluorescência. Os núcleos das células foram corados em azul com DAPI. Aumento de 40x

\subsection{BIOMATERIAL}

Como já mencionado anteriormente o biomaterial usado neste projeto foi desenvolvido especialmente para o nosso modelo ovino por pesquisadores do Instituto Friedrich-Baur-Forschungsinstitut für Biomaterilien da Universitat Bayreuth e Biocer entwicklungs - GMBH, da Alemanha. Convém ressaltar que o biomaterial é formado por duas porções: uma formada por implantes cerâmicos de hidroxiapatita, importante no reparo osteocondral, respectivamente a porção azulada do biomaterial (figura 8A e B) e a outra pelo arcabouço cartilaginoso iniciando com esponjas estáveis liofilizadas de quitosana, o qual foi modificado pela adição de componentes da matriz cartilaginosa nativa como a hialurona, sulfatos de condroitina, sulfato de dermatana e possivelmente colágeno II, respectivamente a porção alaranjada do biomaterial (Figura 8A e B).

A figura $8 \mathrm{~A}$ mostra macroscopicamente o biomaterial onde observamos as suas duas porções e a figura $8 \mathrm{~B}$ a sua estrutura através da MEV. $O$ biomaterial possui com 5,21 milímetros de altura, 5,09 milímetros de diâmetro. 

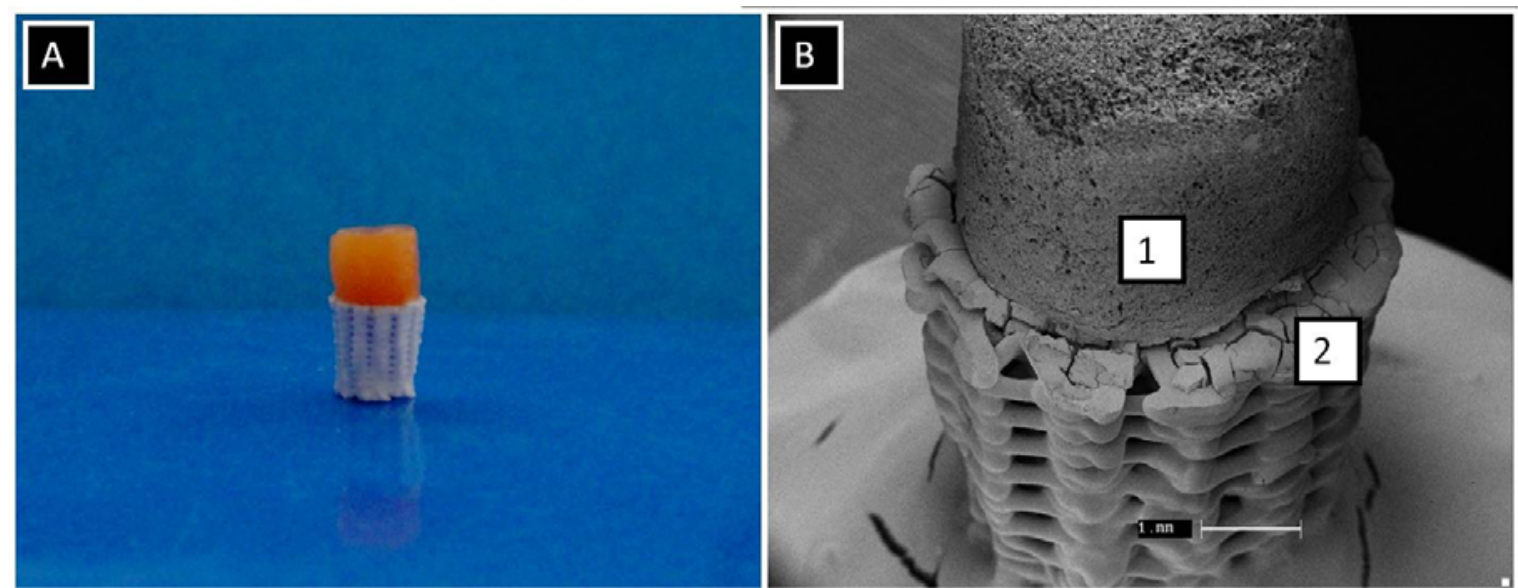

Figura 8 - Imagem do biomaterial macroscopicamente ou por MEV. A) Fotomicrografia demonstrando o biomaterial com os seus dois constituintes: HA, porção inferior e quitosana, porção superior. B) Fotomicrografia do biomaterial evidenciando as suas duas partes. 1) Quitosana e 2) HA. Imagem obtida por MEV. Escala de barra: $1 \mathrm{~mm}$

5.3 Análises do Biomaterial associado ou não as CTPD

A associação das células ao biomaterial foi analisada de diversas maneiras:

\subsubsection{Análise da autofluorescência da quitosana presente no biomaterial}

Para evidenciar a diferença entre a fluorescência adquirida pelas CTPD expressando EGFP e uma possível autofluorescência do biomaterial, as células foram plaqueadas no biomaterial e o mesmo foi submetido à análise por microscopia de fluorescência. Observe na figura 9B que a parte superior do biomaterial composta por quitosana, onde as células são aplicadas, apresenta autofluorescencia, embora seja possível observar nitidamente a diferença entre a autofluorescencia da quitosana e a fluorescência das CTPD que expressam EGFP (Figura 9A e B). 


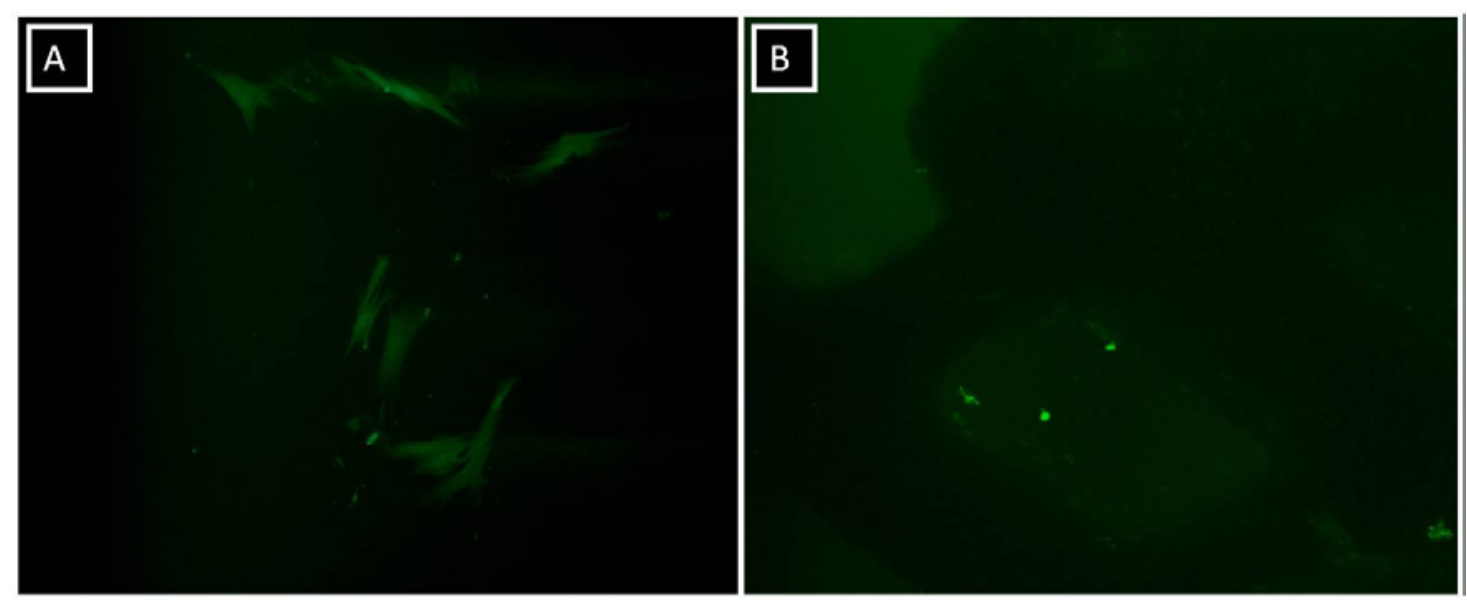

Figura 9 - Fotomicrografia das CTPD associadas ao biomaterial por microscopia óptica de fluorescência. A) CTPD humana expressando EGFP aderidas a quitosana; B) Visualização da autofluorescência obtida pela quitosana. Aumento de 40x

\subsubsection{Análise do potencial de adesão das células ao biomaterial por contagem de célula}

Com o objetivo de obter uma porcentagem de células aderidas ao biomaterial, realizamos uma contagem das células que sobraram no orifício da placa onde o biomaterial foi mantido durante 24 horas após a colocação das células. Neste experimento pudemos observar que a porcentagem de adesão das células ao biomaterial foi alta, em torno de $75 \%$, sendo que apenas $25 \%$ do número total de células encontravam-se aderida no orifício da placa.

\subsubsection{Análise histológica do biomaterial associado ou não as CTPD}

Como mencionado anteriormente, os biomateriais foram mantidos com ou sem células durante 24 horas ou durante um mês. Após este período o 
material foi emblocado e submetido à análise histológica utilizando colorações distintas.

\subsubsection{Análise histológica da parte de quitosana do biomaterial}

Como pretendemos analisar o potencial da terapia por histologia decidimos estudar o perfil histológico da parte de quitosana do biomaterial. Dessa forma, a parte quitosana do biomaterial foi emblocada em parafina e submetida a diversas colorações tais como: HE para análise estrutural do tecido cartilaginoso, picrosírius para marcação do colágeno, azo-carmin para análise estrutural e determinação de fibras colágenas e safranina para visualização do tecido cartilaginoso.

Ainda com o objetivo de verificar se o biomaterial sofre modificações em meio de cultivo o mesmo foi mantido em condições de cultivo após 24 horas e durante um mês, mas nenhuma diferença foi observada e eles mantiveram o perfil de coloração.

\subsection{Coloração de HE}

Na figura 10 mostramos a coloração de HE da porção mais porosa do biomaterial, composta por quitosana. Observe nesta figura a presença de estruturas filamentosas e interligadas, o que caracteriza esta região do biomaterial. 


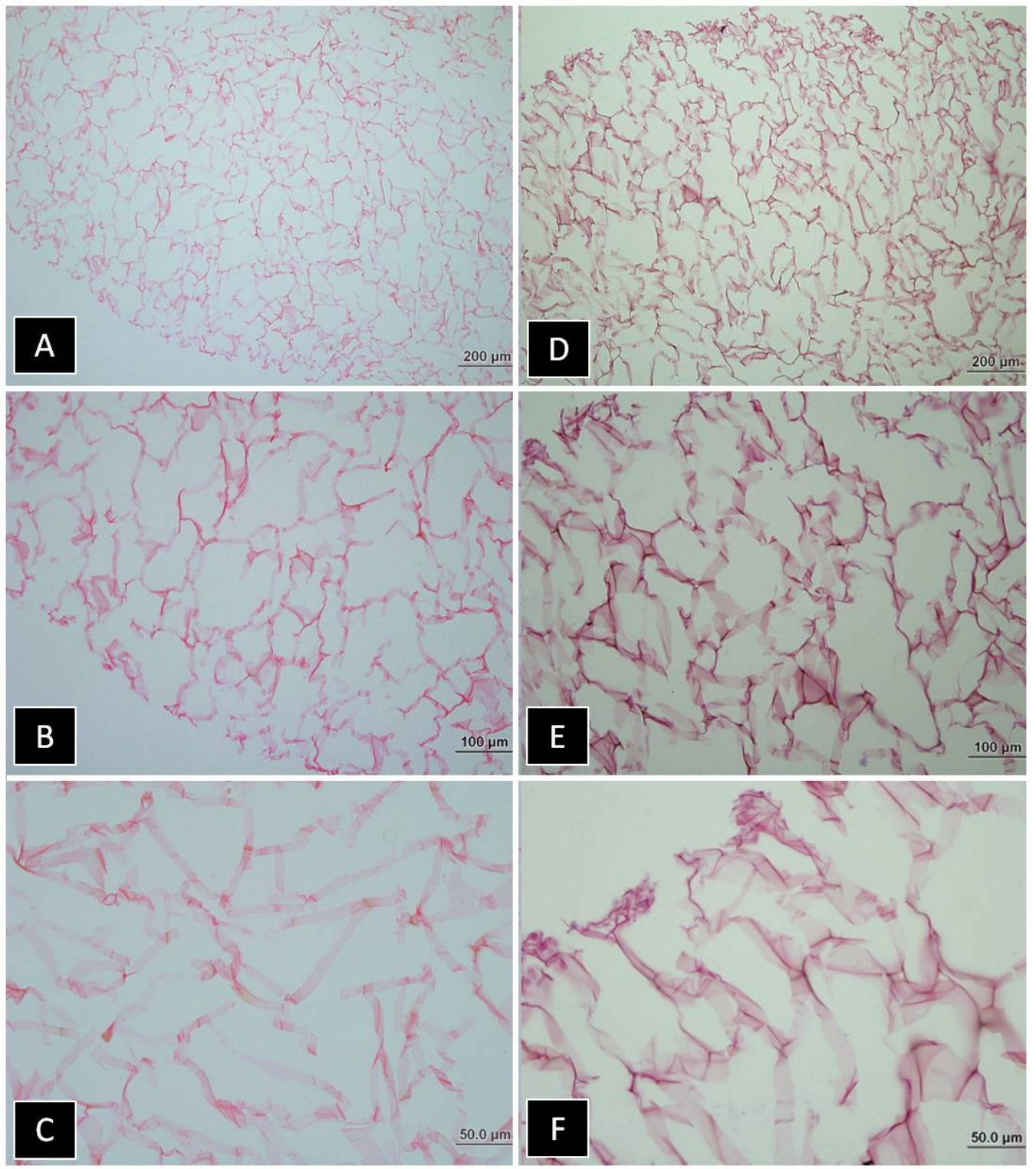

Figura 10 - Fotomicrografia da porção porosa do biomaterial composta por quitosana após cultivo em meio DMEMc 24 horas e um mês utilizando a técnica de HE por microscopia óptica. Observe nas imagens a parte esponjosa da quitosana marcada em rosa e que não houve diferenças de coloração decorrente ao tempo de cultivo. A, B e C) Biomaterial após 24 horas de cultivo em meio DMEMc; D, E e F) Biomaterial após um mês de cultivo.

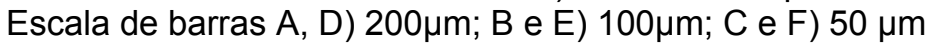

\subsection{Coloração de Picrosírus}

$\mathrm{Na}$ figura 11 mostramos os resultados obtidos com a técnica de coloração picrosírus. Novamente observamos que o tempo de cultivo do biomaterial em meio DMEMc não alterou sua estrutura, como era esperado. $A$ figura $11 \mathrm{~A}, \mathrm{~B}, \mathrm{C}$ mostra os resultados obtidos após 24 horas de cultivo e D, E e F um mês em diferentes aumentos. 


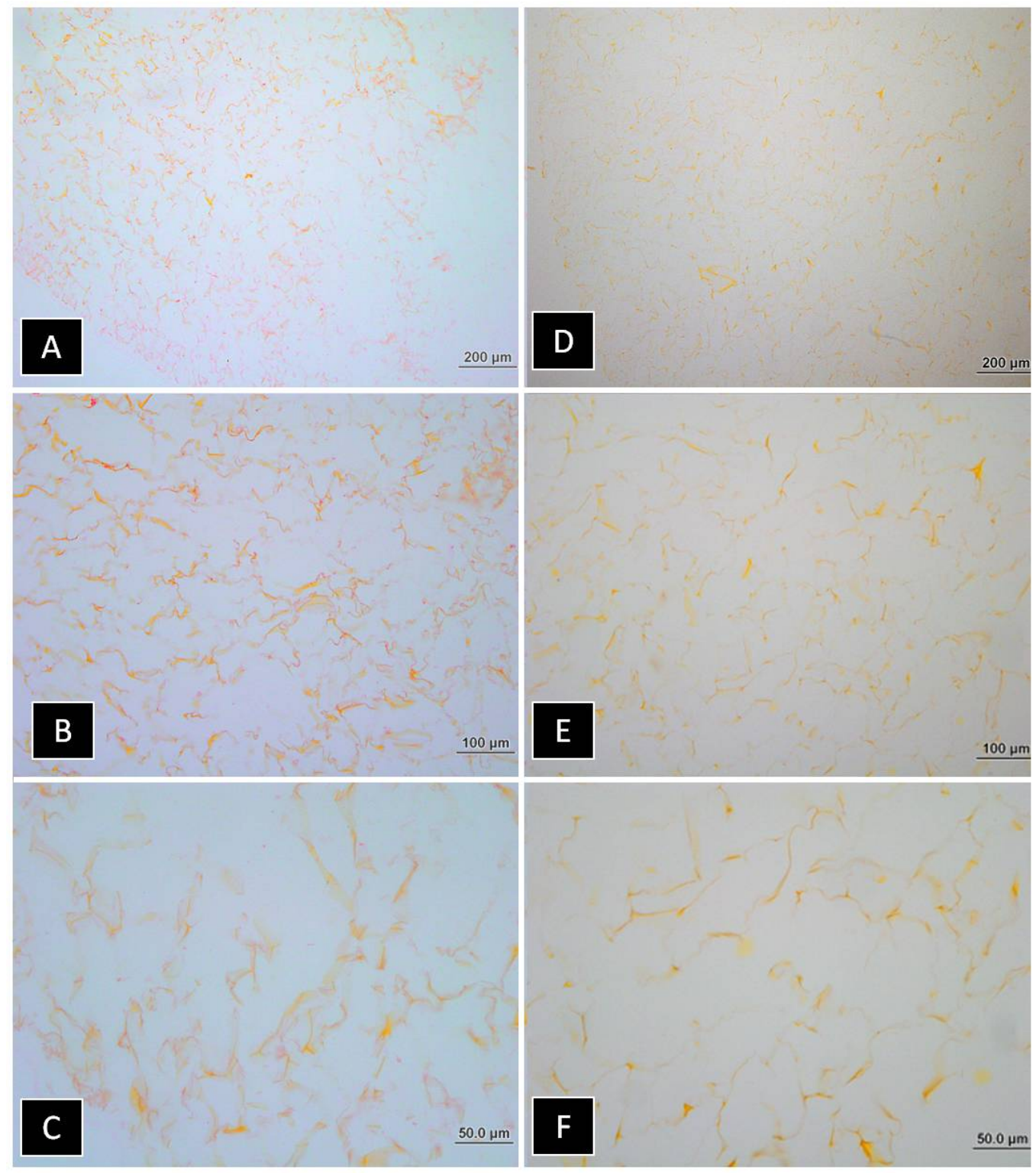

Figura 11 - Fotomicrografia da porção de quitosana do biomaterial utilizando a técnica de coloração de Picrosírus. Imagem obtida por microscopia óptica. A e D) $200 \mu \mathrm{m}$; B e E) $100 \mu \mathrm{m}$; C e F) $50 \mu \mathrm{m}$

\subsection{Coloração de azo-carmin}

A figura 12 representa os resultados obtidos a partir da técnica de coloração do azo-carmin. Como nas colorações anteriores nenhuma alteração digna de nota na estrutura do biomaterial foi observada decorrentes do tempo de incubação do material em meio de cultivo DMEMc. A figura 12A, B, C 
representa 24 horas de incubação e a enquanto que a Figura 12D, E, F corresponde a um mês.

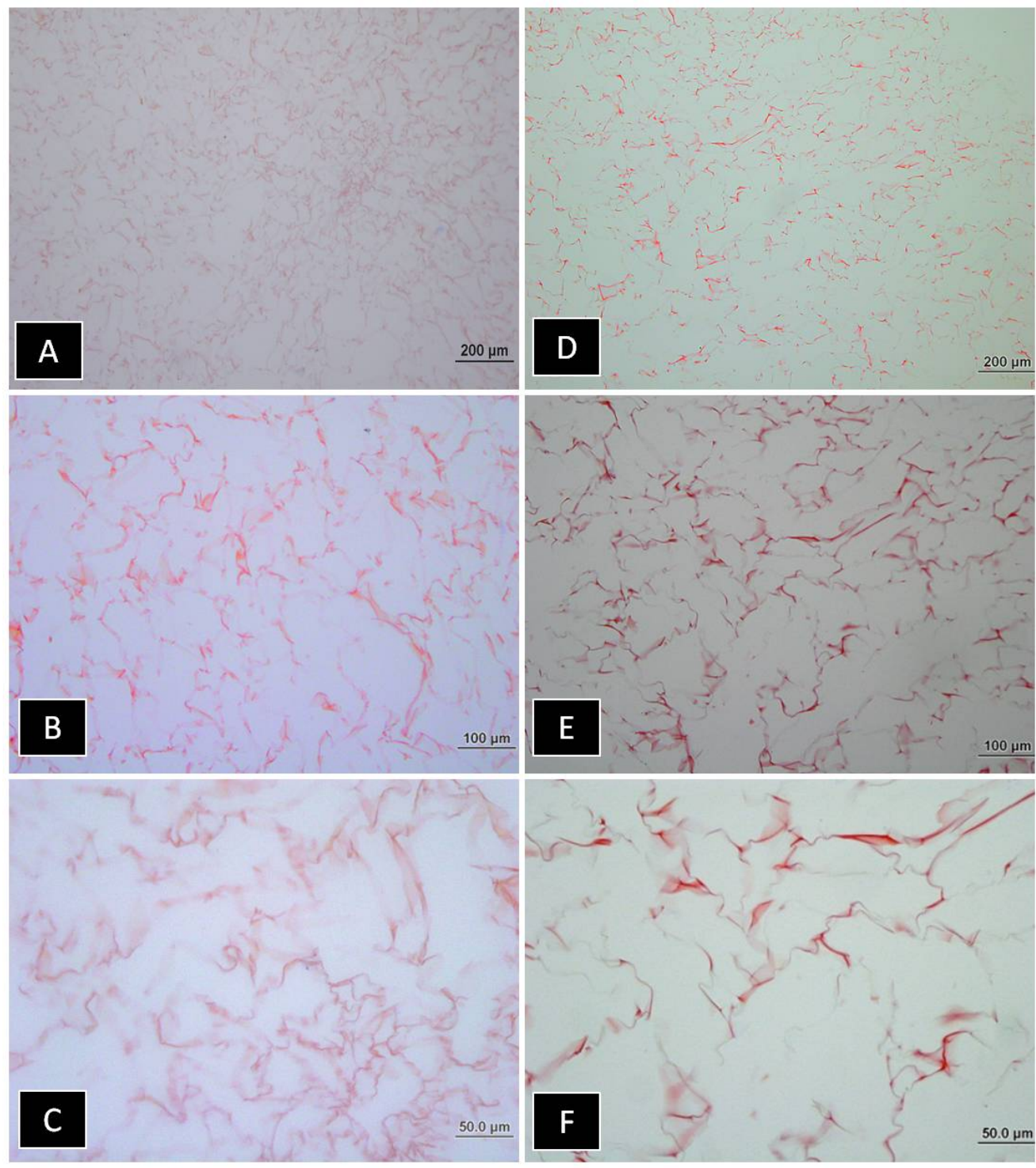

Figura 12 - Fotomicrografia da quitosana utilizando a técnica de azo-carmin. Imagem obtida por microscopia óptica. Escala de barras: A, D) $200 \mu \mathrm{m} ; \mathrm{B}$, E) $100 \mu \mathrm{m} ; \mathrm{C}, \mathrm{F}): 50 \mu \mathrm{m}$

\subsection{Coloração de safranina}

$\mathrm{Na}$ figura 13 observamos os resultados obtidos utilizando a coloração de safranina. Em A, B, C as fotos correspondem a 24 horas de cultivo do biomaterial e em D, E, F equivale a um mês. Os resultados são semelhantes aos anteriores, sem alterações relevantes em relação ao tempo de cultivo. 


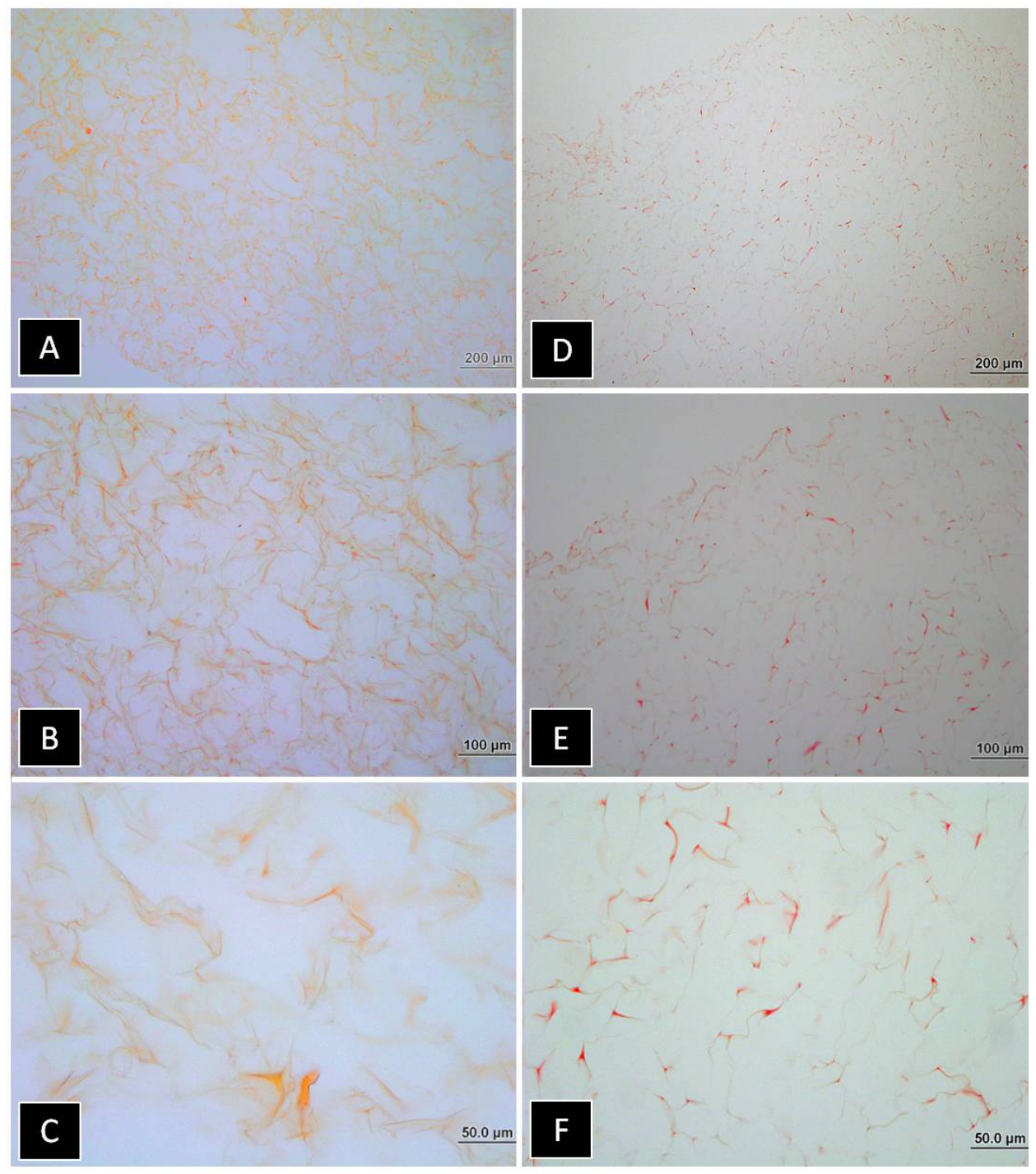

Figura 13 - Fotomicrografia da porção de quitosana do biomaterial utilizando a técnica de Azo-Carmin por microscopia óptica. Observe a parte esponjosa do biomaterial, quitosana, sendo marcada pela cor amarela. Escala de barras: A, D) $200 \mu \mathrm{m}$; B, E) $100 \mu \mathrm{m}$; C, F) 50 $\mu \mathrm{m}$

5.3.3.2 Análise histológica da parte de quitosana do biomaterial associada as CTPD

Visando ainda a melhor análise histológica dos ovinos após tratamento, as CTPD foram colocadas sobre a porção de quitosano do biomaterial durante 24 horas e um mês. Após este período esta região foi submetida as rotinas histológicas e diferentes colorações. Observamos que apesar do 
tempo de incubação das células terem sido diferentes, nenhuma grande modificação foi observada.

\subsection{Coloração de HE}

A técnica de coloração de HE favorece a análise estrutural de todos os constituintes e foi utilizada para a visualização das CTPD no quitosano. A figura 14A, B, C corresponde ao cultivo das CTPD humana associado ao biomaterial por 24 horas e em 14D, E, F um mês. As setas pretas indicam a presença das CTPD, com sua morfologia característica, nos diferentes tempos de incubação. Uma observação interessante é que após 24 horas de cultivo, as células encontravam-se mais próximas uma das outras e em um mês mais afastadas, porém, aparentemente mais bem aderidas à porção de quitosano do biomaterial. 


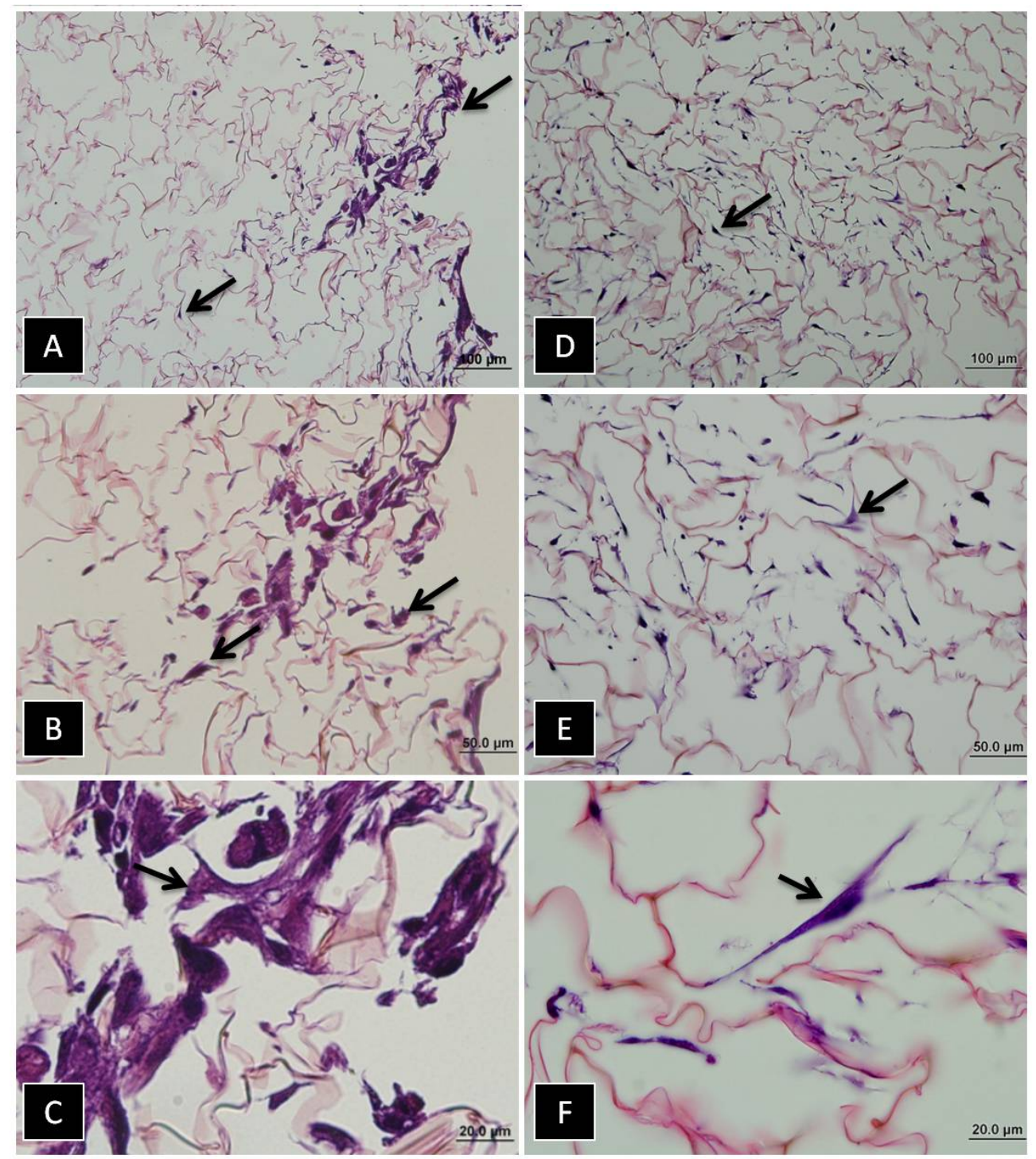

Figura 14 - Fotomicrografia das CTPD humana aderidas a quitosana do biomaterial utilizando a técnica de coloração de $\mathrm{HE}$, com 24 horas e um mês de cultivo. As setas pretas mostram as CTPD humana aderidas a quitosana. Imagem obtida por microscopia óptica. Escala de Barras: A, D) $100 \mu \mathrm{m}$; B, E) $50 \mu \mathrm{m}$; C, F) $20 \mu \mathrm{m}$

\subsection{Coloração de picrosírus}

Na figura 15 temos os resultados obtidos na coloração de picrosírus onde as células são evidenciadas com uma coloração amarela escura, sendo distinguido da porção de quitosana, marcado em amarelo claro. As setas indicam a presenças das CTPD. Em A, B e C temos 24 horas de incubação e $D, E$ e $F$, um mês. Observe que não observamos diferenças significativas relacionadas ao tempo de cultivo das células ao biomaterial. 


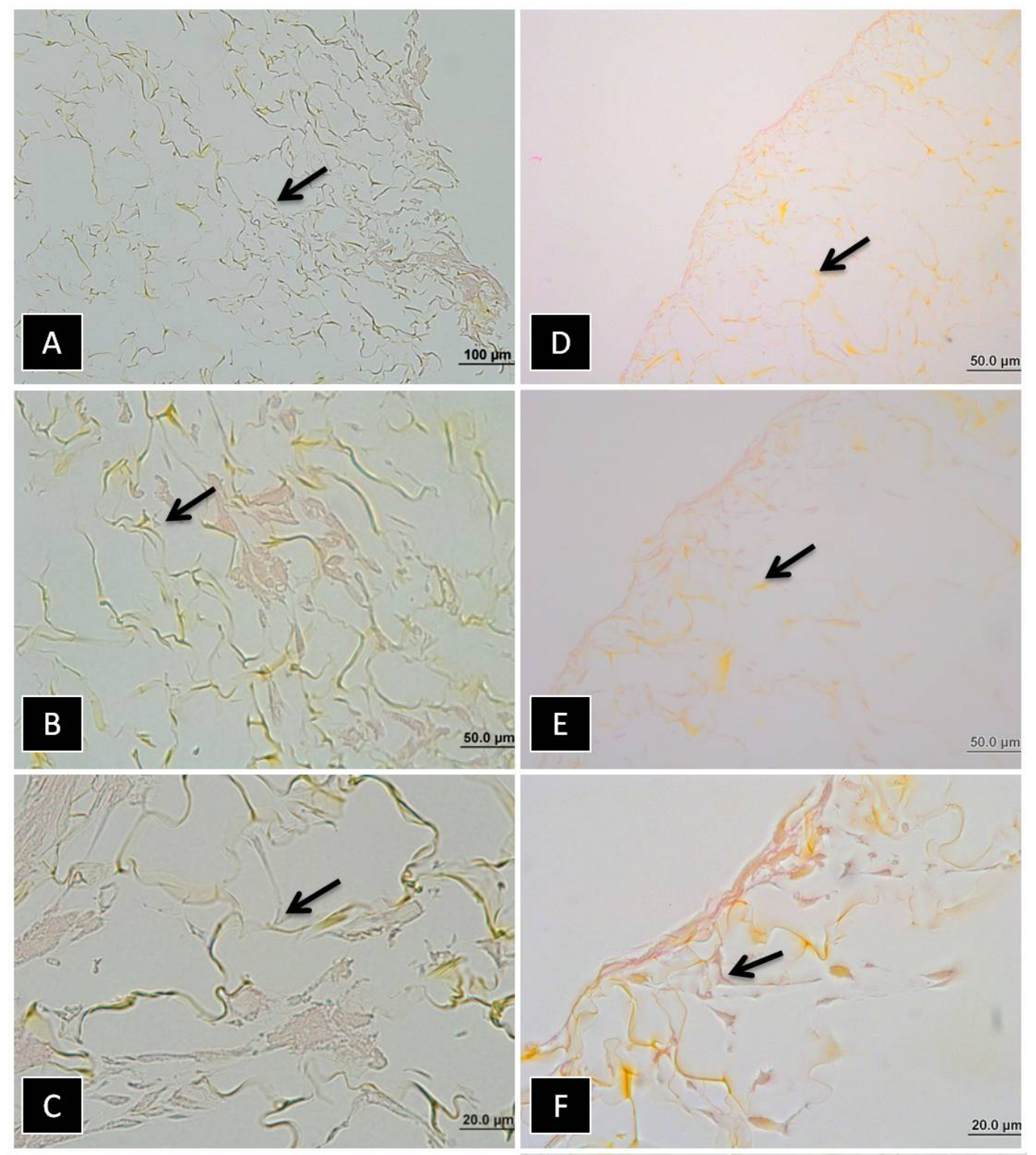

Figura 15 - Fotomicrografia das CTPD humana aderidas a quitosana utilizando a técnica de picrosírus, com 24 horas e um mês de cultivo através de microscopia óptica. As setas pretas indicam a presença das CTPD humana aderidas a quitosana. Escala de barras: A, D) $100 \mu \mathrm{m} ; \mathrm{B}, \mathrm{E})$

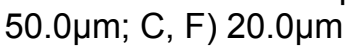

\subsection{Coloração de azo-carmin}

Com a técnica de azo-carmin, pudemos observar as células com uma coloração azul escuro, identificadas pelas setas pretas sendo distinguido da porção de quitosana, que se apresentam em vermelho claro. Note que tanto as células quanto o quitosano possuem as suas características evidenciadas 
e preservadas o que facilita a análise. Na figura 16A, B e C apresentamos as colorações obtidas após 24 de cultivo das células ao quitosano e 16D, E e F após um mês. Nenhuma diferença significativa no perfil da coloração foi observada.

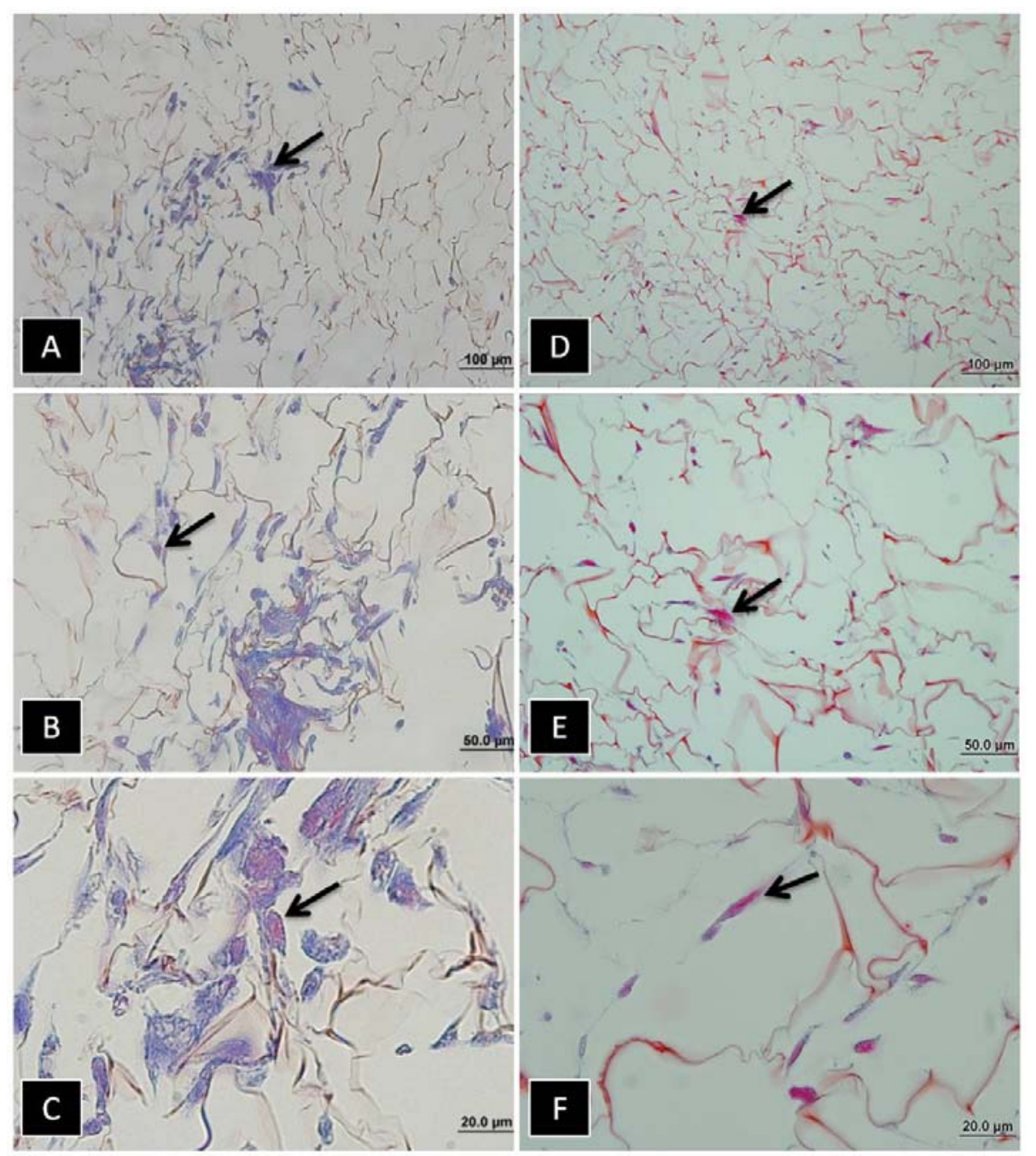

Figura 16 - Fotomicrografia das CTPD humana aderidas a quitosana utilizando a técnica de coloração de azo carmin, com 24 horas e um mês de cultivo. As pretas indicam a presença das CTPD humana (coloração azul) aderidas a quitosana (coloração vermelha). Imagem obtida por microscopia óptica. Escala de barras: A, D) $100 \mu \mathrm{m}$; B, E) $50.0 \mu \mathrm{m}$; C, F) $20.0 \mu \mathrm{m}$

\subsection{Coloração de safranina}

$\mathrm{Na}$ figura 17 foi utilizada a coloração de safranina para a visualização das CTPD humana aderidas no quitosano, região mais porosa do biomaterial. 
As células (setas pretas) foram evidenciadas numa coloração rosa escuro, sendo que os seus núcleos apresentavam-se mais escuros e evidentes. Já, o quitosano é visualizado na cor rosa claro. As CTPD humana associado ao biomaterial estavam nas mesmas condições das técnicas anteriores e com resultados semelhantes, sem nenhuma alteração relevante em relação ao tempo de cultivo, onde na figura 17A, B e C, temos 24 horas de incubação e $D, E$ e $F$, um mês.

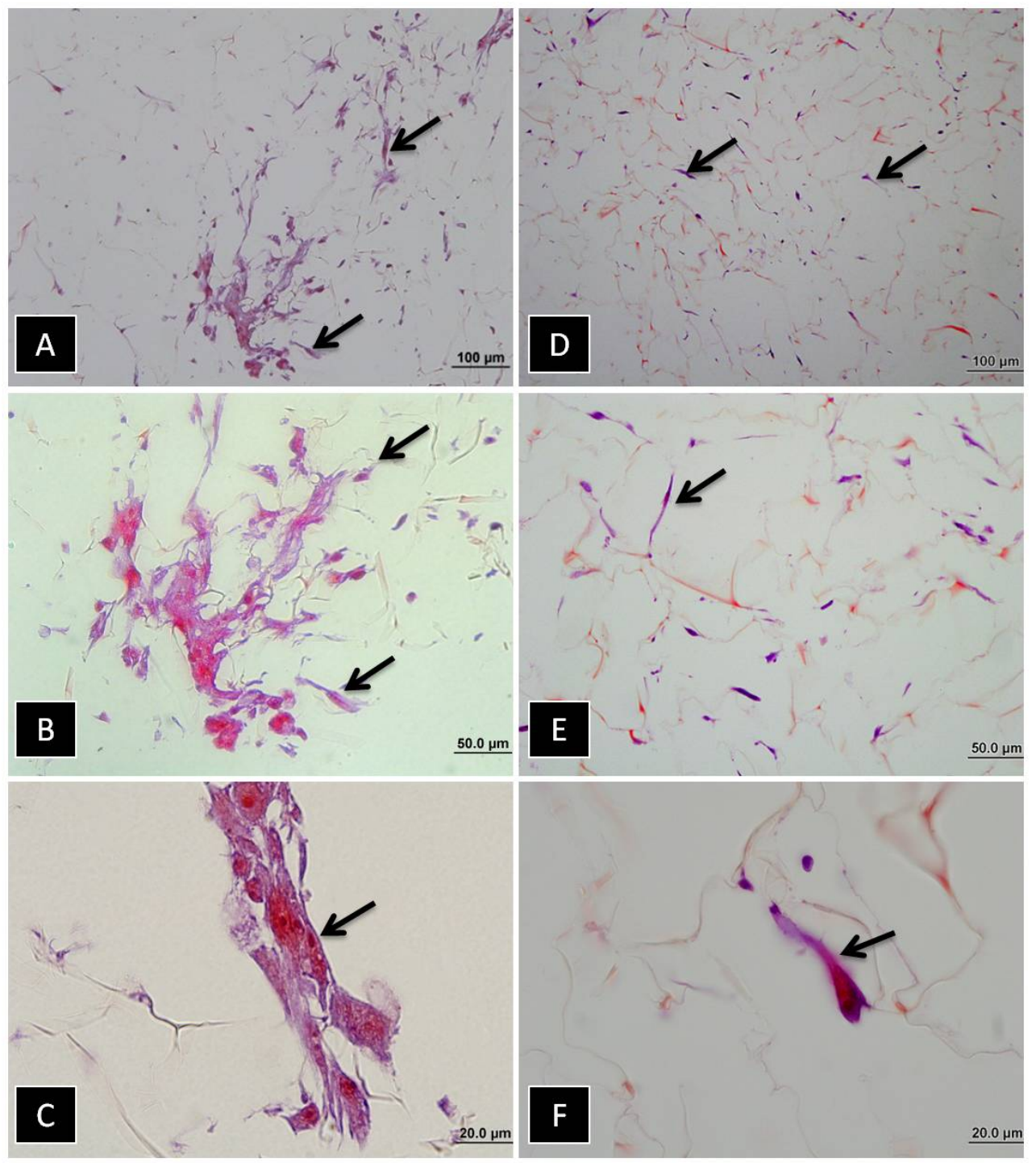

Figura 17 - Fotomicrografia das CTPD humana aderidas a quitosana através da coloração de safranina, com 24 horas e um mês de cultivo por microscopia óptica. As setas pretas indicam as CTPD humanas aderidas a quitosana. Escala de barras: A, D) $100 \mu \mathrm{m}$; B, E) $50 \mu \mathrm{m}$; C, F) $20 \mu \mathrm{m}$ 


\subsubsection{Análise do biomaterial associado ou não as CTPD por microscopia eletrônica de varredura}

Os experimentos de microscopia eletrônica de varredura foram realizados com o objetivo de analisar a associação das células ao biomaterial e também o biomaterial não associado as células.

\subsubsection{Biomaterial não associado a CTPD}

Através da MEV pudemos comprovar as características estruturais do biomaterial. A figura 18A mostra as duas porções distintas do biomaterial, sendo que a porção superior, quitosano esta evidenciada nas figuras $18 \mathrm{~B}$ e a inferior, HA na figura $18 \mathrm{C}$. Na figura 19 também temos uma visão bem detalhada do biomaterial evidenciando as suas duas porções.
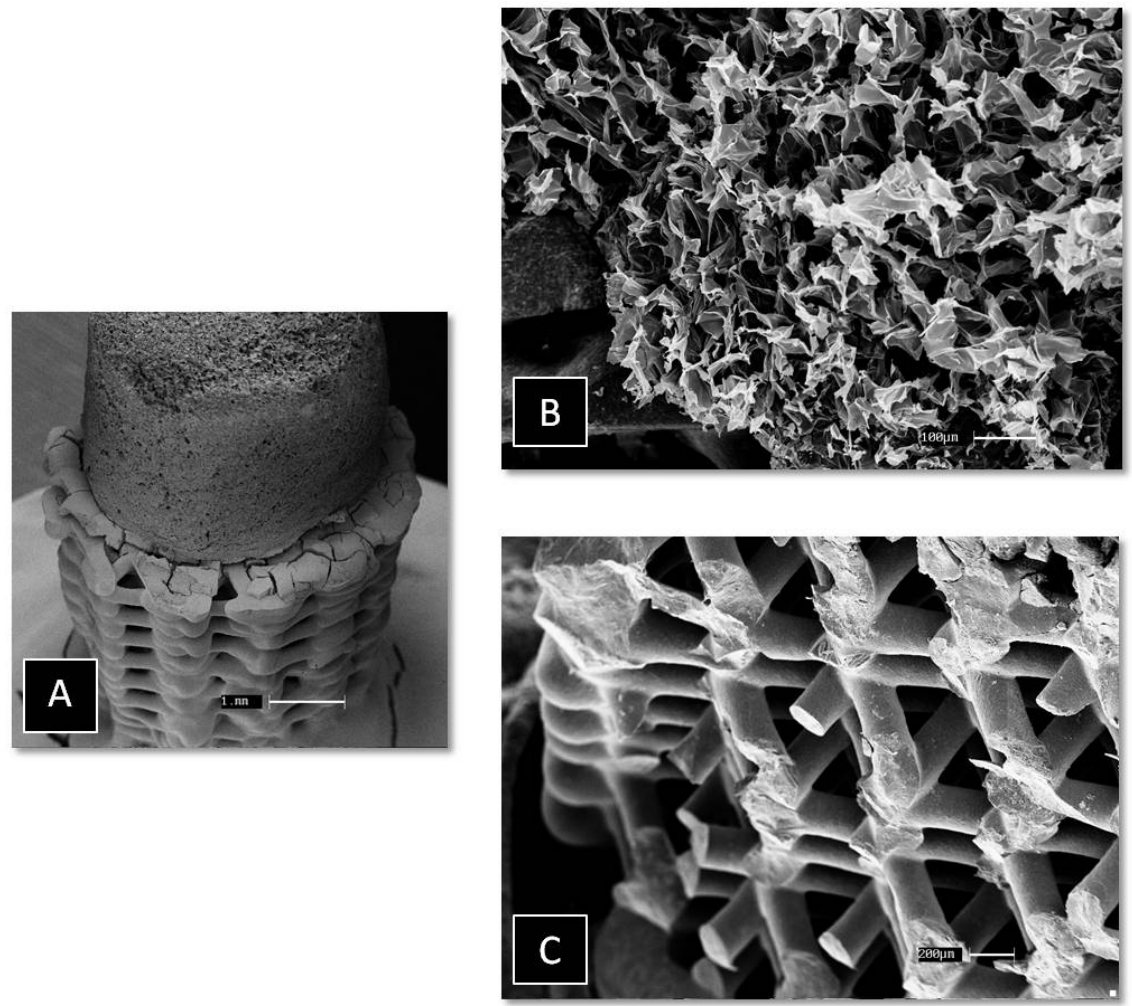

Figura 18 - Fotomicrografia do biomaterial por MEV. A) Biomaterial formado por duas porções. B) Porção superior de quitosano que representa a parte mais esponjosa do biomaterial; C) Porção inferior constituída de HA que representa a estrutura mais rígida do biomaterial. Escala de barra: $1 \mathrm{~mm}$ 

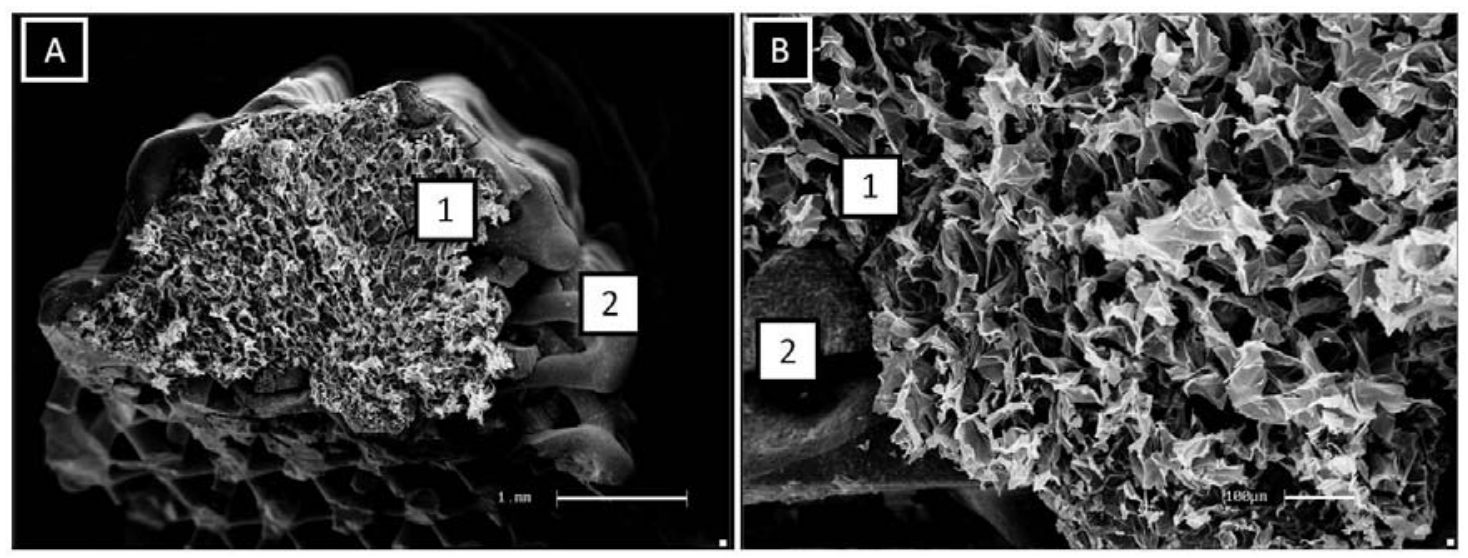

Figura 19 - Fotomicrografia do biomaterial evidenciado suas duas porções por MEV. A) Vista frontal do 1: quitosana e 2: HA. B) Visão mais aproximada do biomaterial, 1: parte cartilaginosa, constituído de quitosana; 2: HA. Escala de barra: A) $1 \mathrm{~mm}$; B) $200 \mu \mathrm{m}$

\subsubsection{Biomaterial associado a CTPD}

$\mathrm{Na}$ figura 20 mostramos os resultados de MEV obtidos após a associação do biomaterial as CTPDs humanas. As setas vermelhas (A e B) representam as células já, a seta azul representam a porção de quitosano do biomaterial. Observe que as células estão associadas a porção de quitosano do biomaterial como era esperado, convém lembrar que a porção de quitosano é a parte mais porosa do biomaterial, que pode possivelmente originar cartilagem.
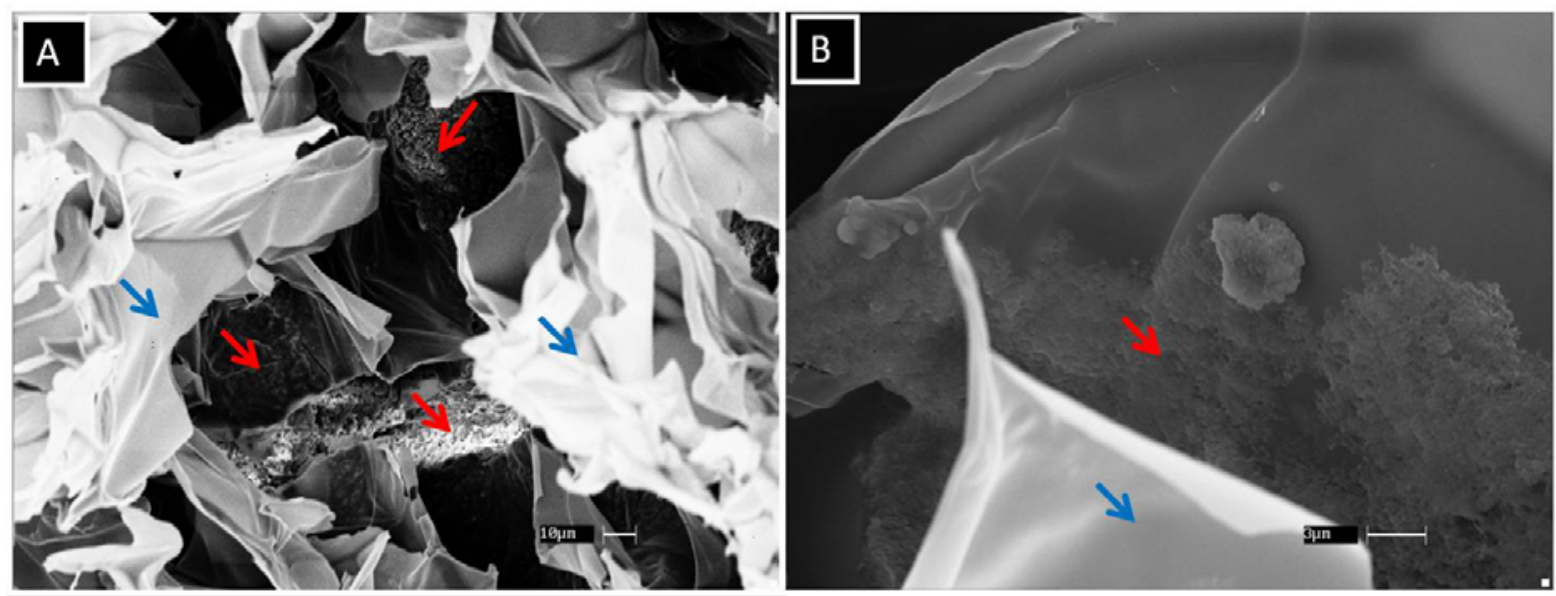

Figura 20 - Fotomicrografia do biomaterial associado a CTPD humana por MEV. Observe que a parte de quitosana do biomaterial está associada a CTPD como esperado. A) Visão geral da associação do biomaterial as células e B) Visão aproximada da associação das células ao biomaterial. As setas azuis representam a marcação da quitosana, parte mais esponjosa do biomaterial e as setas vermelhas: as CTPD. Escala de barras: A e B) $1 \mathrm{~mm}$ 


\subsection{PROCEDIMENTO CIRÚRGICO DE IMPLANTAÇÃO DAS CÉLULAS ASSOCIADAS OU NÃO AO BIOMATERIAL}

O procedimento cirúrgico da lesão foi realizado seguindo o padrão cirúrgico descrito no item 4.6 de materiais e métodos. Em resumo, quatro lesões foram realizadas na articulação femorotibiopatelar de ovinos, sendo que a primeira recebeu a injeção apenas de CTPD (figura 21A), a segunda, biomaterial (figura 21B), a terceira CTPD humana associadas ao biomaterial (figura $21 \mathrm{C}$ ) e, por último, o controle, que não recebeu nenhum tratamento para a lesão (figura 21D).

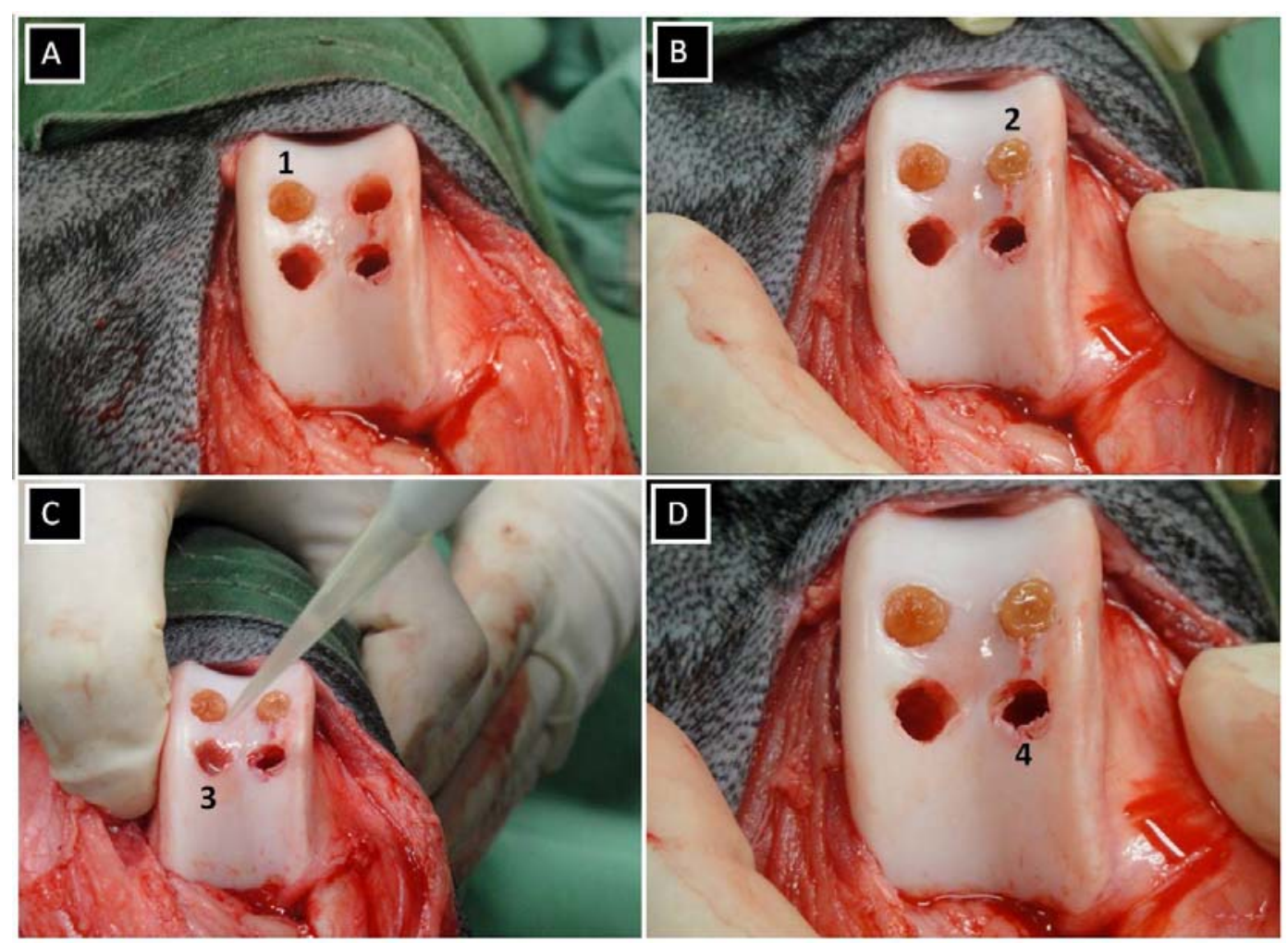

Figura 21 - Foto macroscópica do implante das CTPD humana associadas ou não ao biomaterial nas lesões ósseo-cartilaginosa induzidas na articulação femorotibiopatelar de ovinos. A) Inserção do biomaterial sem associação com CTPD humana no defeito osteocondral identificado pelo número 1; B) Biomaterial associado às CTPD humana no defeito osteocondral identificado pelo número 2; C) Somente CTPD aplicadas no defeito osteocondral identificado pelo número 3 ; D) Orifício controle sem células e/ou biomaterial, identificado com o número 4. Imagens obtidas por uma máquina fotográfica 


\subsection{Monitoramento clínico dos animais tratados com biomateriais associados ou não as CTPD humanas}

Visando monitorar a evolução clinica dos animais tratados, realizamos os seguintes exames diagnósticos: radiografia, ultrassonografia e artroscopia.

\subsubsection{Exame Radiográfico}

A seguir, nas figuras 22 a 29 mostraremos os resultados obtidos nos exames radiológicos. Em todos os exames radiográficos aqui apresentados, o membro direito foi utilizado como controle e está sendo representado por A e C e o membro esquerdo o qual foi submetido ao procedimento cirúrgico por $B$ e E. Em A, B temos os resultados obtidos das articulações femorotibiopatelares dos animais em posição mediolateral e em C e D posição caudocranial.

Na figura 22 e 23 temos respectivamente os resultados obtidos após 36 e 66 dias do procedimento cirúrgico. Convém ressaltar que nenhuma alteração foi observada na articulação femorotibiopatelar direita, como era esperado (Figuras 22 e $23 \mathrm{~A}$ e C). Já, em relação à articulação femorotibiopatelar esquerda (Figuras 22 e 23 D) observa-se quatro orifícios radiotransparentes, sendo dois proximais e dois distais, simetricamente dispostos no sulco troclear do fêmur. Convém ressaltar que na figura 22B, os orifícios proximais apresentavam-se mais evidentes em relação aos orifícios mostrados na figura 23B.

Os dois orifícios radiotransparentes proximais (Figura 22 e 23B) medem 0,8 cm de diâmetros cada e apresentam-se preenchidos com material radiopaco de formato cilíndrico, medindo $0,5 \times 0,5 \mathrm{~cm}$ de diâmetro cada. Além disso, nota-se um halo de esclerose difuso junto aos orifícios que medem 0,5 x 0,5 cm de diâmetro cada. Observou-se ainda uma suave opacificação de radiopacidade água intra-articular difusa e discreta radiopacidade óssea 
subcondral heterogênea difusa da patela e discreto osteófito periarticular lateral e medial fêmoro-tibial (Figura 22 e 23B).
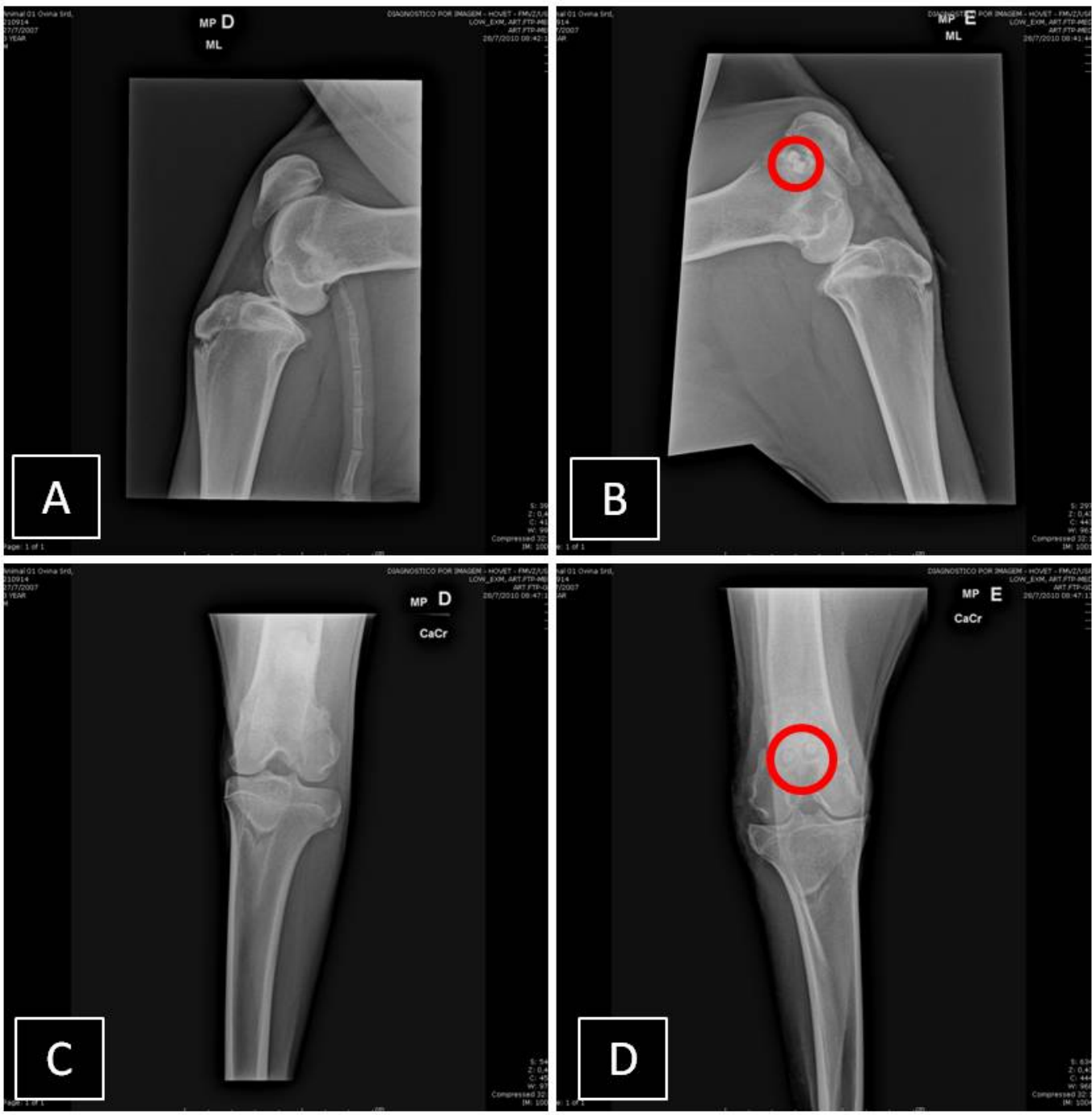

Figura 22 - Exames radiográficos da articulação femorotibiopatelar esquerda após 36 dias do procedimento cirúrgico sendo o membro direito utilizado como controle. A, B) Membro em posição mediolateral direito e esquerdo respectivamente; C, D) Posição caudocranial. Em evidência, observe em $B$ dois defeitos proximais feitos no sulco troclear femoral, preenchidos com biomateral e biomaterial associado a CTPD humana e em D) os quatro defeitos osteocondrais, proximais e distais 

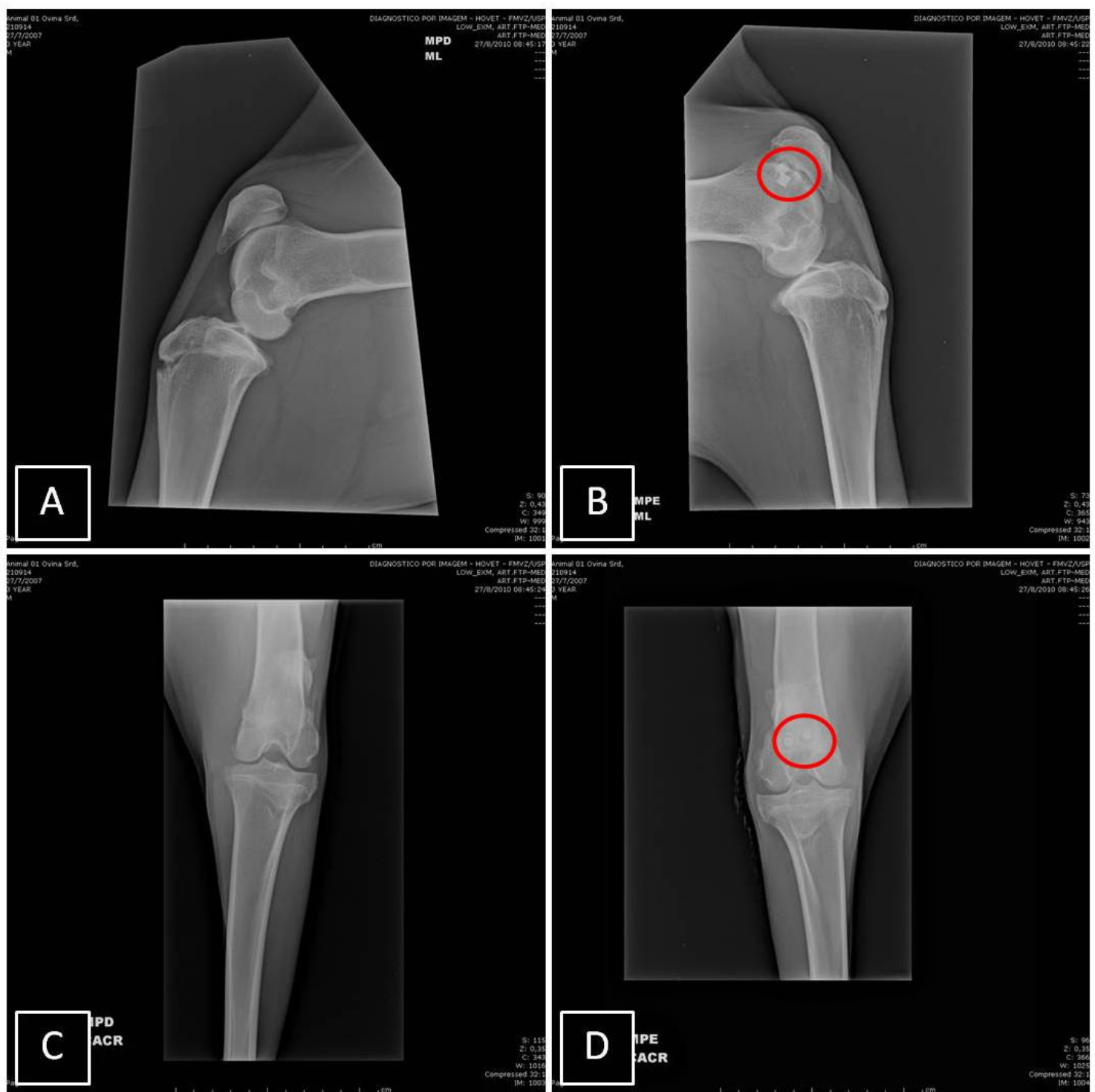

Figura 23 - Exames radiográficos da articulação femorotibiopatelar esquerda após 66 dias do tratamento cirúrgico. O Membro pélvico direito foi utilizado como controle. A, B) Posição mediolateral dos membros direito e esquerdo; C, D) Posição caudocranial. B) Visualização dos dois defeitos proximais feitos no sulco troclear femoral do membro esquerdo, preenchidos com biomateral e biomaterial associado as CTPD humana; D) Percepção dos quatro defeitos osteocondrais proximais e distais

As figuras 24, 25 e 26 apresentam os resultados obtidos após 87, 125 e 159 dias do procedimento cirúrgico onde observamos as seguintes diferenças em relação aos exames anteriores (figura 22 e 23): menor intensidade do halo de esclerose difuso junto aos orifícios e menor 
espaçamento radiotransparente (Figura 24, 25 e 26B). Observou-se também uma menor opacificação de radiopacidade água intra-articular difusa e menor evidência da radiopacidade óssea subcondral heterogênea difusa da patela e discreto osteófito periarticular lateral e medial fêmoro-tibial (Figura 24, 25 e 26B).
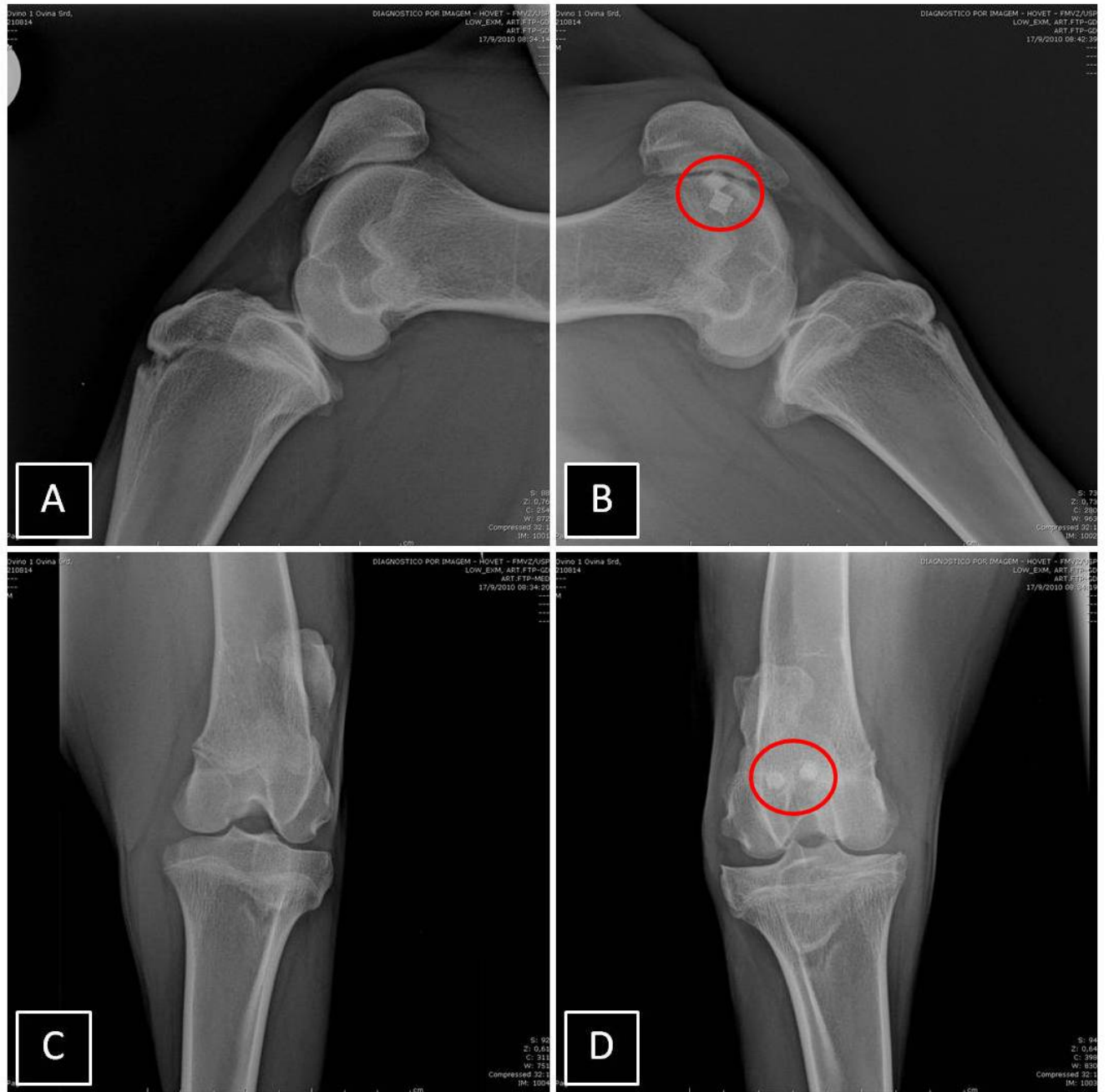

Figura 24 - Exames radiográficos da articulação femorotibiopatelar bilateral. Membro pélvico direito controle e o esquerdo com 87 dias após o procedimento cirúrgico. A, B) Membro direito e esquerdo respectivamente na posição mediolateral; C, D) Posição caudocranial. Observe em B os dois defeitos proximais feitos no sulco troclear femoral, preenchidos com biomateral e biomaterial associado às CTPD humana $e$ na $D$ os quatro defeitos osteocondrais, proximais e distais 


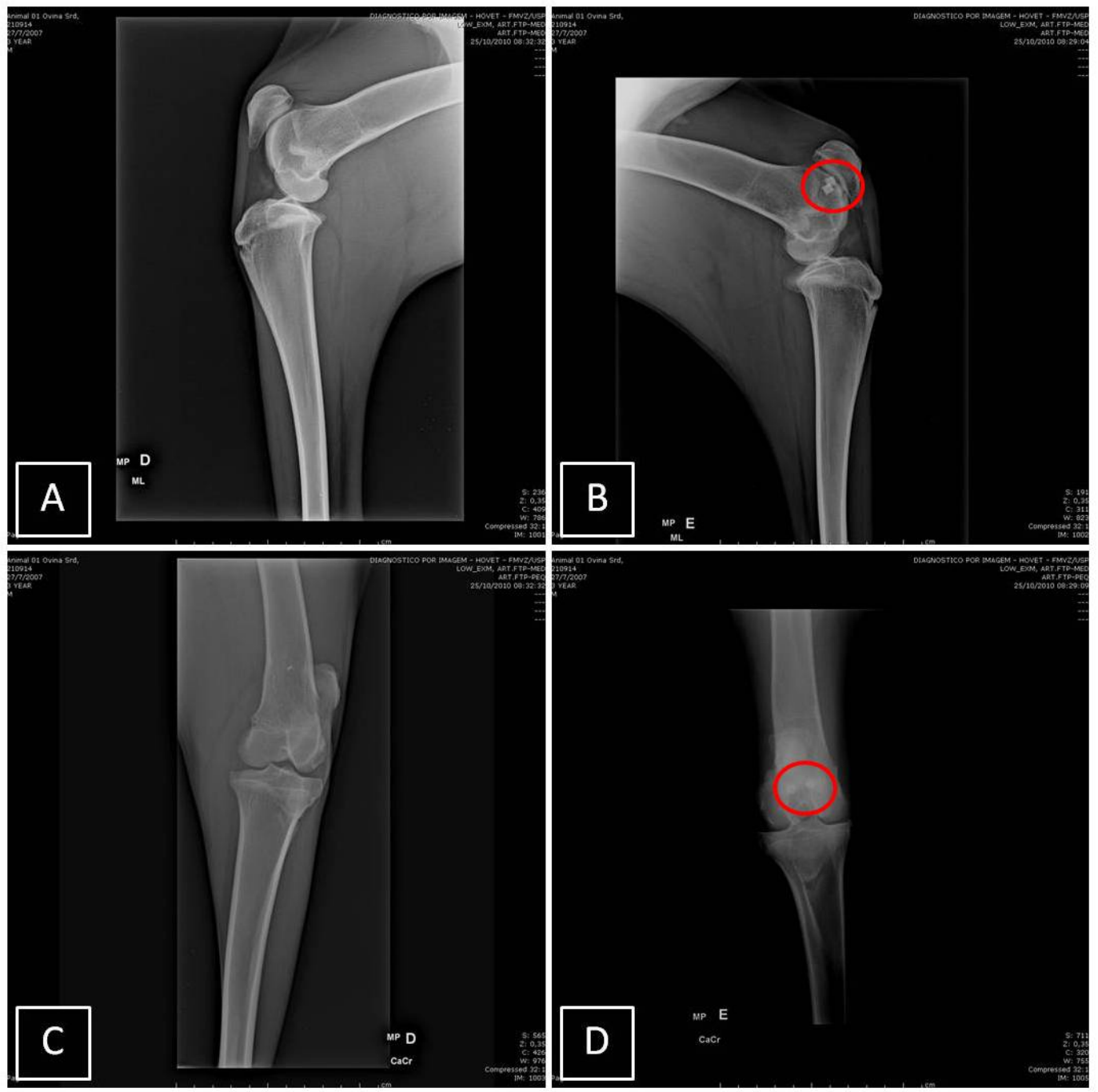

Figura 25 - Exames radiográficos da articulação femorotibiopatelar esquerdo com 125 dias após o procedimento cirúrgico. O membro direito foi utilizado como controle. A, B) Posição mediolateral, membros direito e esquerdo respectivamente; C, D): Posição caudocranial. Em B temos uma visualização dos dois defeitos proximais feitos no sulco troclear femoral, preenchidos com biomateral e biomaterial associado as CTPD humana. D) Quatro defeitos osteocondrais, proximais e distais 

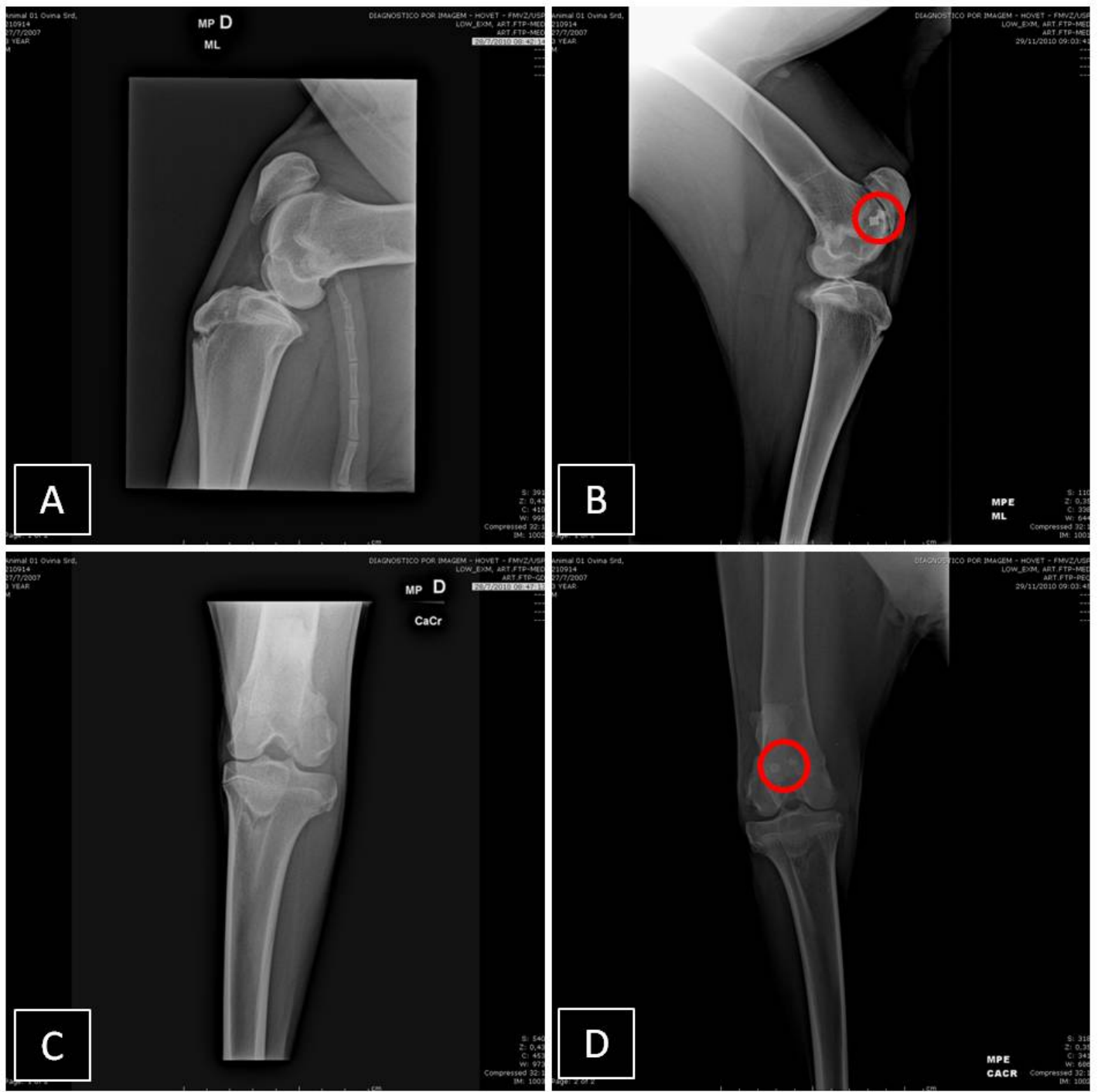

Figura 26 - Exames radiográficos da articulação femorotibiopatelar bilateral. O membro pélvico direito foi utilizado controle e o esquerdo com 159 dias após o procedimento cirúrgico. A, B) Membro direito e esquerdo respectivamente em posição mediolateral; C, D) Posição caudocranial. B) Visualização dos dois defeitos proximais feitos no sulco troclear femoral, preenchidos com biomateral e biomaterial associado as CTPD humana. D) Percepção dos quatro defeitos osteocondrais, tanto os proximais quanto os distais

Novos exames radiográficos foram realizados após 231 dias (Figura 27), 279 (Figura 28) e 300 dias (Figura 29) do procedimento cirúrgico e nenhuma alteração em tecido ósseo subjacente foi observada.

Os exames de radiográficos foram feitos para poder visualizar as lesões criadas, além de mostrar que o biomaterial estava devidamente inserido na lesão e não ocasionou nenhum tipo de rejeição no animal. Entretanto, utilizando o exame radiográfico como parametro de imagem, não foi possível observar nenhuma alteração ou melhora da lesão provocada. 


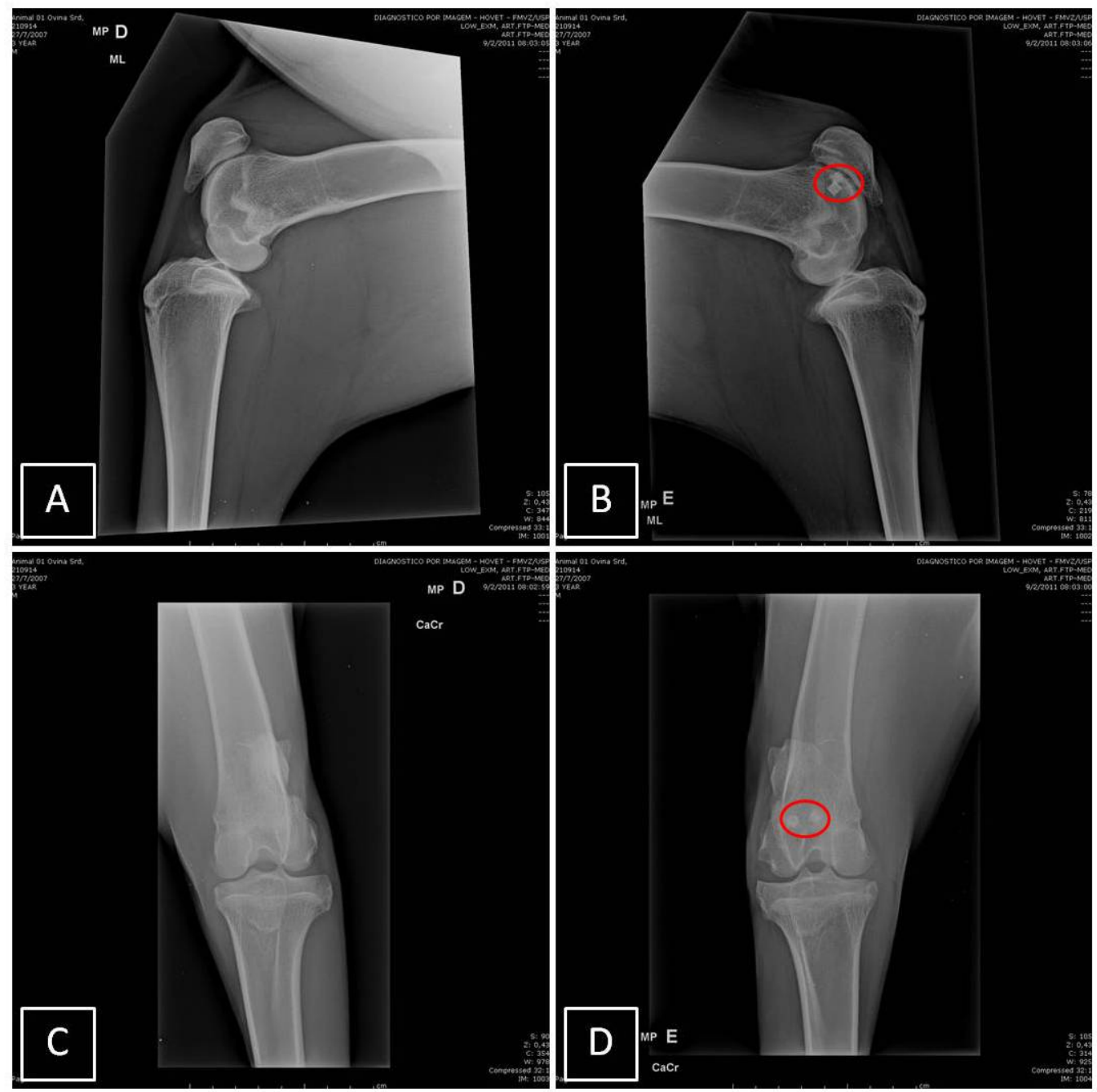

Figura 27 - Exames radiográficos da articulação femorotibiopatelar esquerda após 231 dias do procedimento cirúrgico sendo o membro direito utilizado como controle. A, B) Posição mediolateral dos lados direito e esquerdo respectivamente; C e D) Posição caudocranial. Em (B) podemos observar os dois defeitos proximais feitos no sulco troclear femoral, preenchidos com biomateral e biomaterial associado as CTPD humana. Já, em (D) temos uma percepção dos quatro defeitos osteocondrais, tanto os proximais quanto os distais 

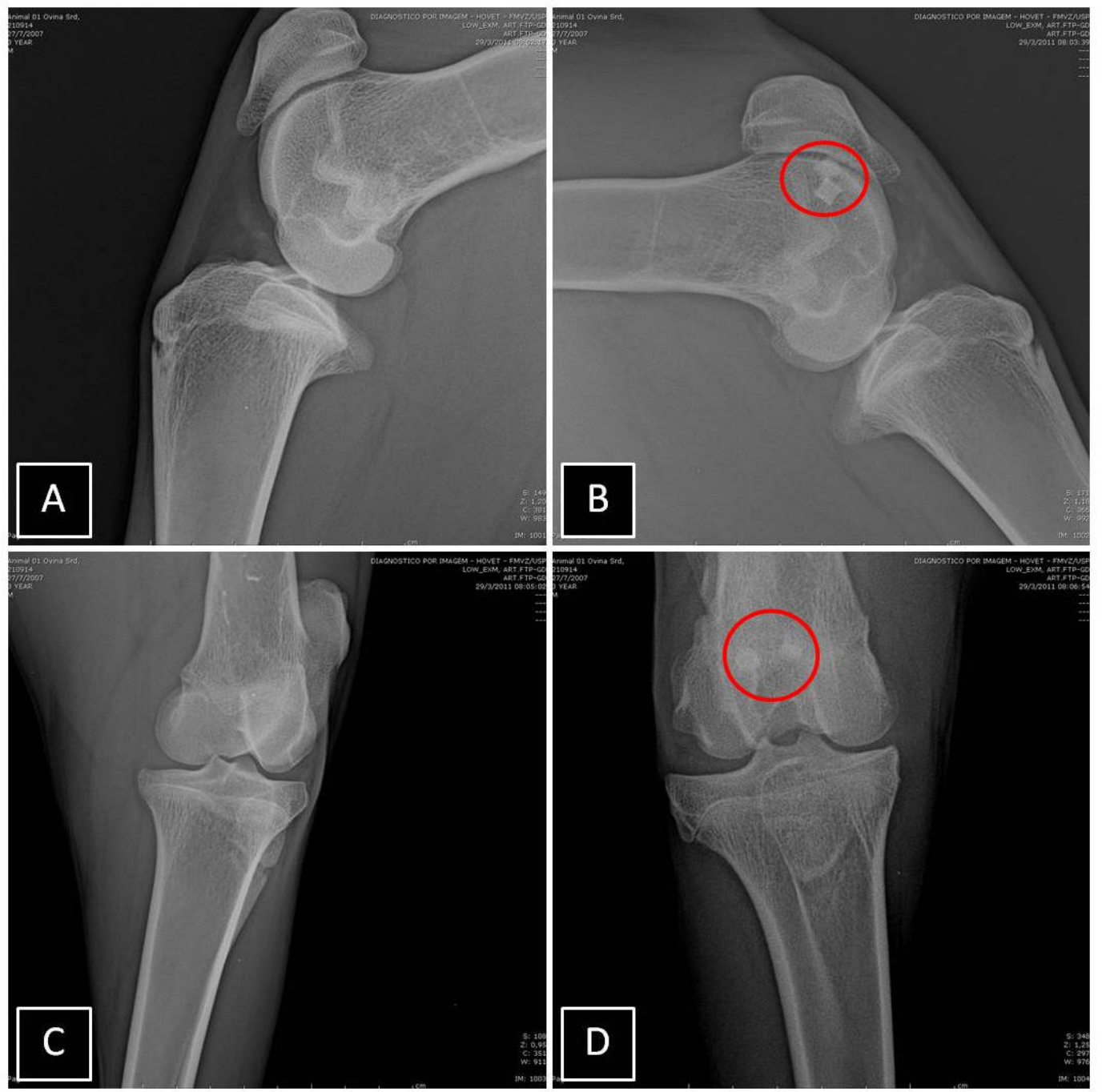

Figura 28 - Exames radiográficos da articulação femorotibiopatelar esquerdo com 279 dias após o procedimento cirúrgico. O membro pélvico direito normal foi utilizado como controle para comparação com membro pélvico esquerdo, no qual foi realizado o procedimento cirúrgico. A, B) Membros direito e esquerdo em posição mediolateral e em C, D) Posição caudocranial. B) Visualização dos dois defeitos proximais feitos no sulco troclear femoral, preenchidos com biomateral e biomaterial associado as CTPD humana. D) Percepção dos quatro defeitos osteocondrais, tanto os proximais quanto os distais 

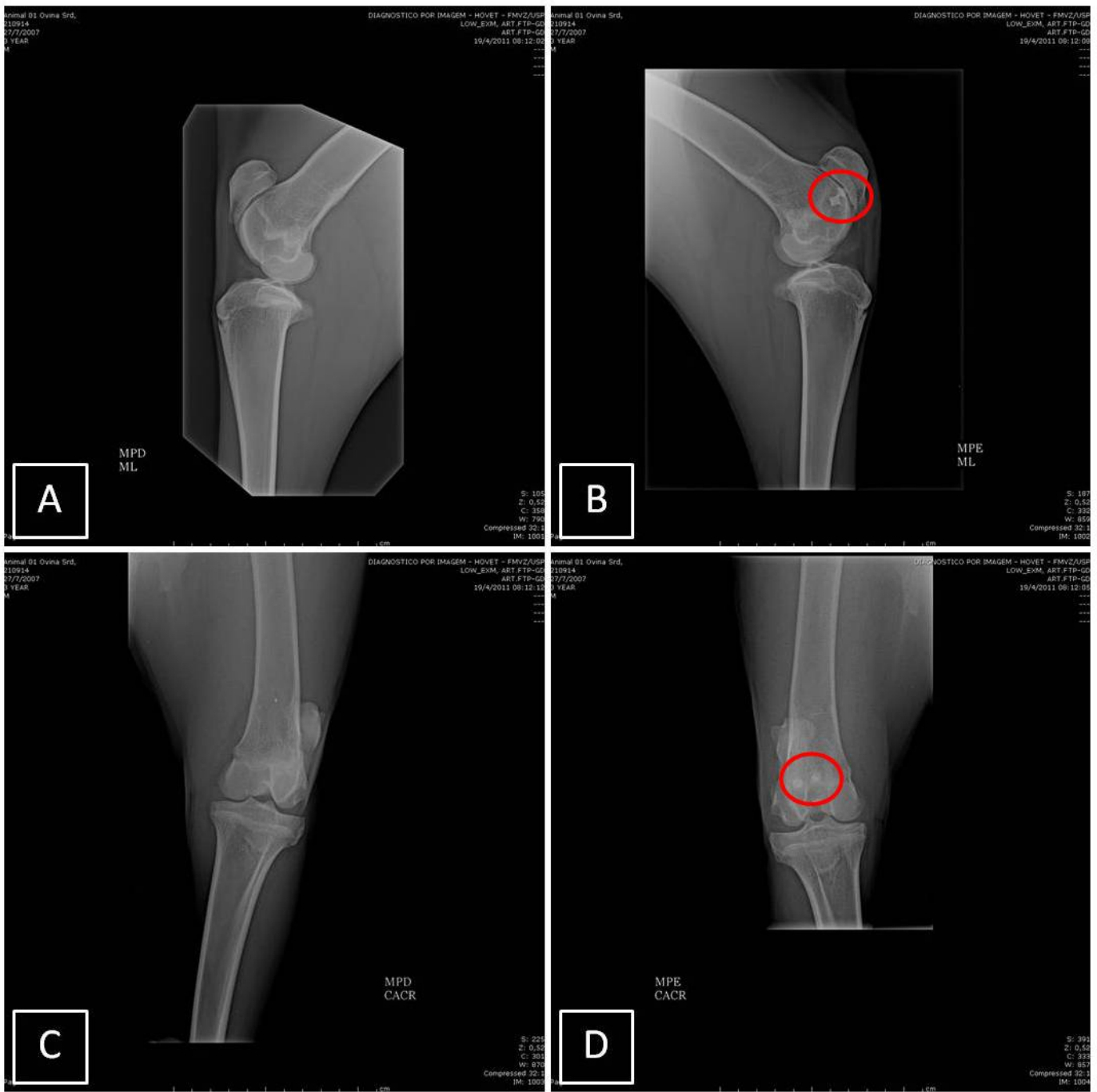

Figura 29 - Exames radiográficos da articulação femorotibiopatelar esquerdo com 300 dias após o procedimento cirúrgico. Membro pélvico direito foi utilizado como controle e no esquerdo foi realizado o procedimento cirúrgico. A, B) O membro encontra-se na posição mediolateral, direito e esquerdo respectivamente; C, D) Posição caudocranial. Em (B) mostramos os dos dois defeitos proximais feitos no sulco troclear femoral, preenchidos com biomateral e biomaterial associado as CTPD humana. Já, $D$ temos os quatro defeitos osteocondrais, tanto os proximais quanto os distais

\subsubsection{Exame Ultrassonográfico}

Exames ultrassonográficos foram realizados com o objetivo de analisar os resultados obtidos após a implantação do biomaterial associado ou não as CTPD na articulação femorotibiopatelar esquerda (Figuras 30 a 36). 
Os resultados obtidos nos exames ultrasonográficos após 66 dias do procedimento cirúrgico estão apresentados na figura 30. A figura 30A representa uma imagem transversal dos defeitos subcondrais em porção proximal do côndilo medial onde a seta 1 indica a presença do biomaterial e a seta 2 representa biomaterial com as CTPD humana no côndilo lateral. Já, a figura 30B e C mostram respectivamente uma imagem longitudinal do defeito subcondral em côndilo medial (seta 1- biomaterial) e côndilo lateral (seta 2 biomaterial com as CTPDs humanas). A imagem transversal (Figura 30D) e longitudinal (Figura 30E) dos defeitos subcondrais em porção distal do côndilo medial está evidenciada pela seta 1, as CTPD humana. Na seta 2 das figuras 30D e F está evidenciado o controle no côndilo lateral sendo respectivamente imagem transversal e longitudinal.

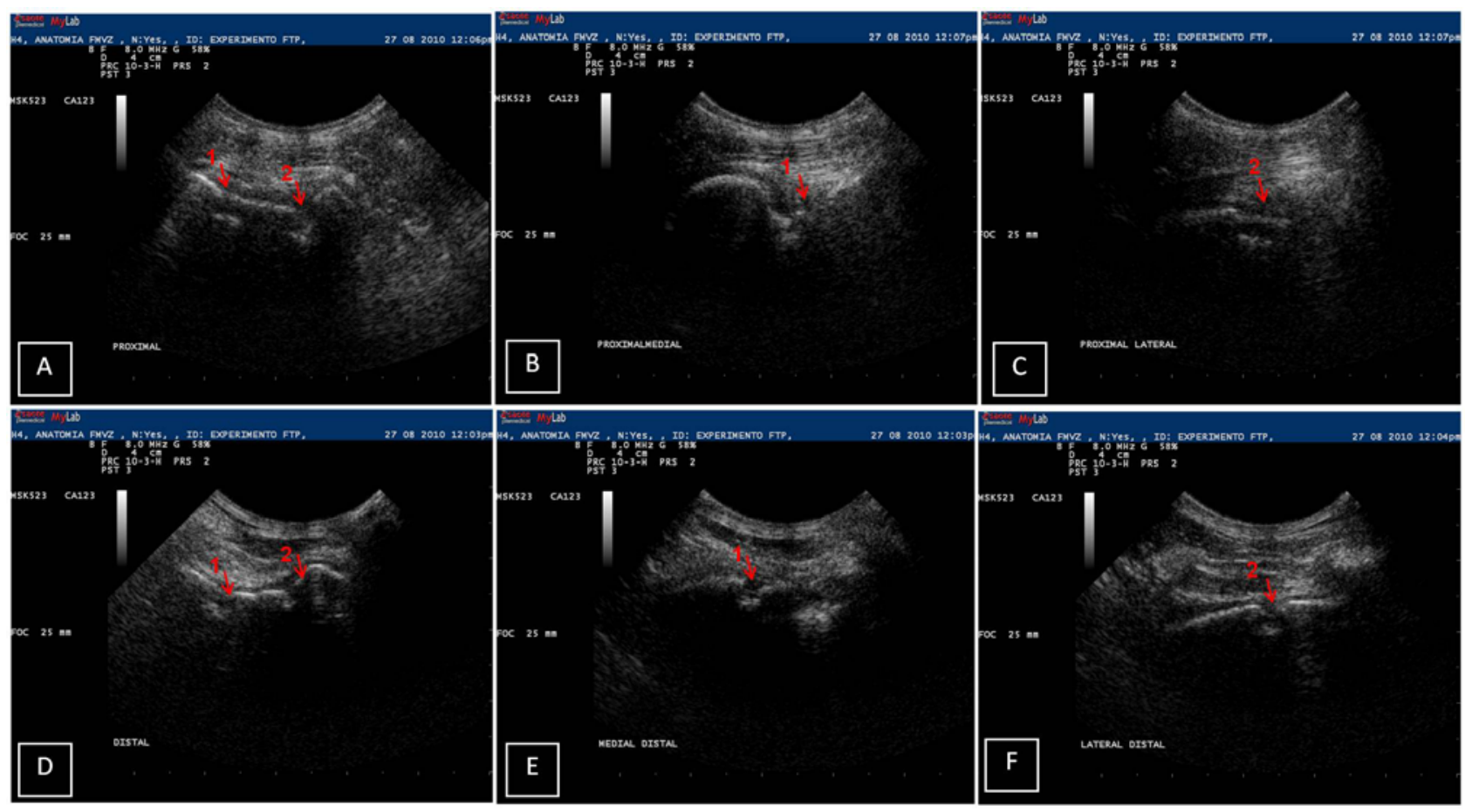

Figura 30 - Imagem ultrassonográfica da articulação femorotibiopatelar esquerda, 66 dias do pós-cirúrgico. A, B, C) Imagens ultrassonográficas das lesões proximais; D, E, F) Lesões distais. A) Imagem transversal dos defeitos subcondrais em porção proximal do côndilo medial, (seta 1 biomaterial) e no condilo lateral (seta 2 - biomaterial com as CTPDs humanas); B) Imagem longitudinal do defeito subcondral em côndilo medial (seta 1 - biomaterial); C) Imagem longitudinal do defeito subcondral em côndilo lateral (seta 2 - biomaterial com as CTPDs humanas); D) Imagem transversal dos defeitos subcondrais em porção distal do côndilo medial (seta 1 - CTPD humana) e do côndilo lateral (seta 2 - controle); E) Imagem longitudinal do defeito subcondral em côndilo medial (seta 1 - CTPD humana); F) imagem longitudinal do defeito subcondral em côndilo lateral (seta 2 - controle) 
Na figura 31 visualizamos as imagens, 87 dias após cirurgia onde nenhuma alteração foi observada, não há mudança nos formatos, profundidades e no conteúdo de preenchimento das lesões.

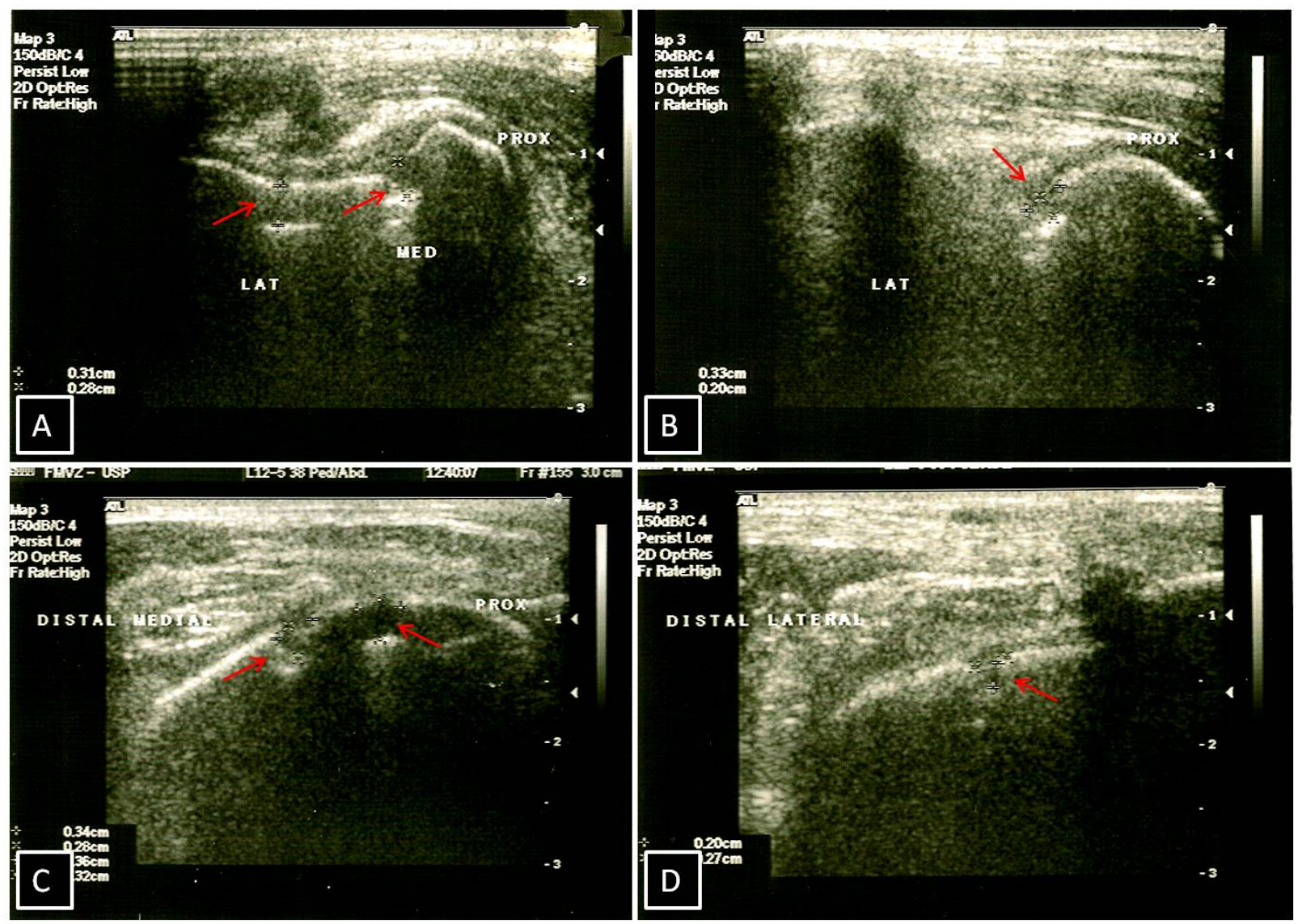

Figura 31 - Imagem ultrassonográfica das lesões subcondrais da articulação femorotibiopatelar esquerda, 87 dias pós-cirúrgico. A) Imagem transversal dos defeitos subcondrais em porção proximal dos côndilos; B) Imagem longitudinal do defeito subcondral proximal em côndilo lateral: C) Imagem longitudinal dos defeitos subcondrais proximal e distal em côndilo medial. D) Imagem longitudinal do defeito subcondral distal em côndilo lateral. As setas vermelhas indicam o local das lesões

Após 122 dias do procedimento cirúrgico, as lesões medial proximal e lateral distal foram mantidas. Já, nas lesões, lateral proximal e medial distal evidencia-se um arrasamento, os quais se apresentam como uma linha de base irregular (Figura 32). 


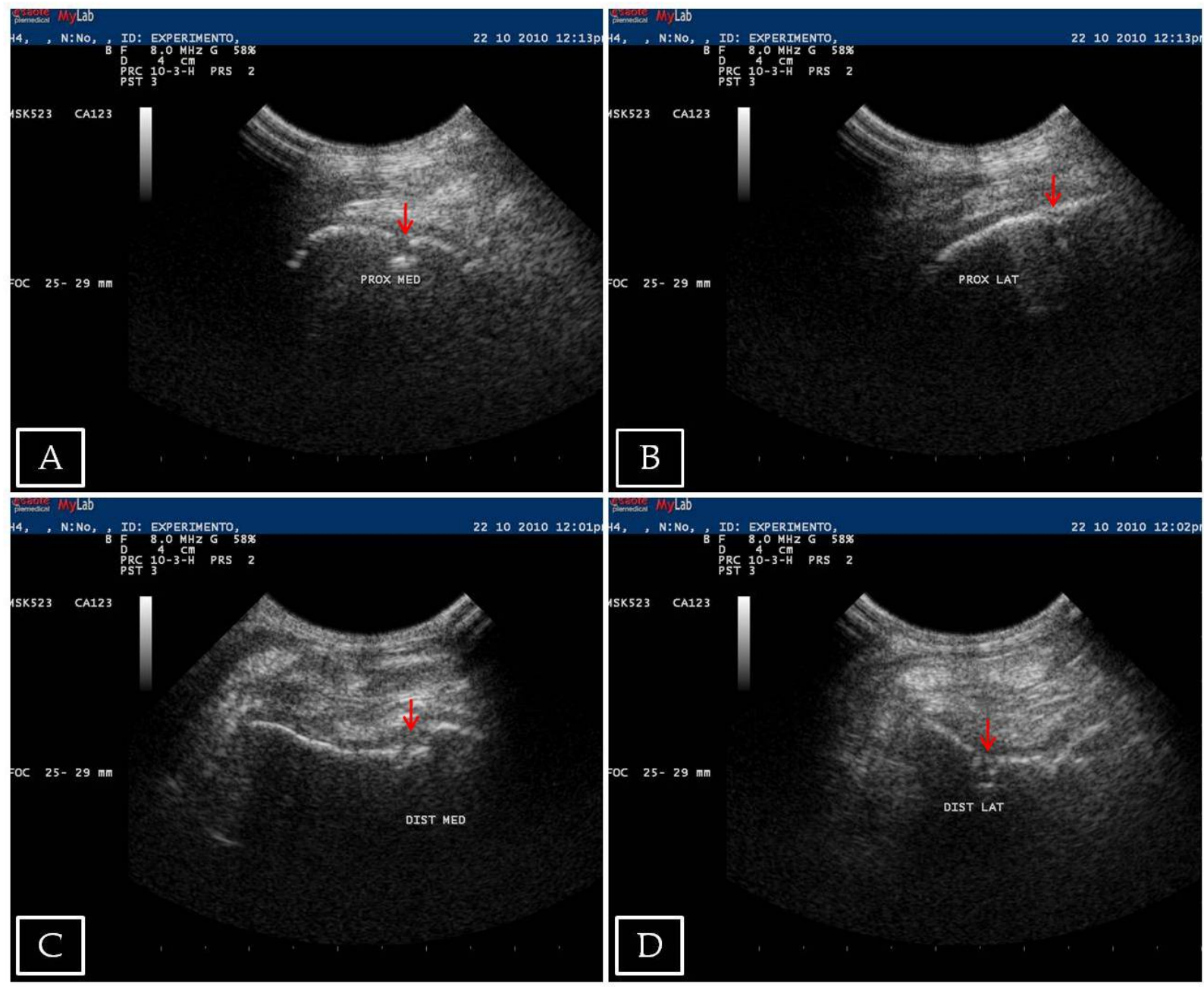

Figura 32 - Imagem ultrassonográfica da articulação femorotibiopatelar esquerda, 122 dias póscirúrgico. A) Imagem longitudinal do defeito subcondral proximal em côndilo medial (seta - biomaterial). B) Imagem longitudinal do defeito subcondral proximal em côndilo lateral (seta - biomaterial com as CTPDs humanas). C) Imagem transversal do defeito subcondral distal em côndilo medial (seta - CTPD humana). D) Imagem transversal do defeito subcondral distal em côndilo lateral (seta - controle)

No exame ultrassonográfico após 156 dias da cirurgia nenhuma alteração foi observada quando comparada ao exame anterior como mostra a figura 33. 


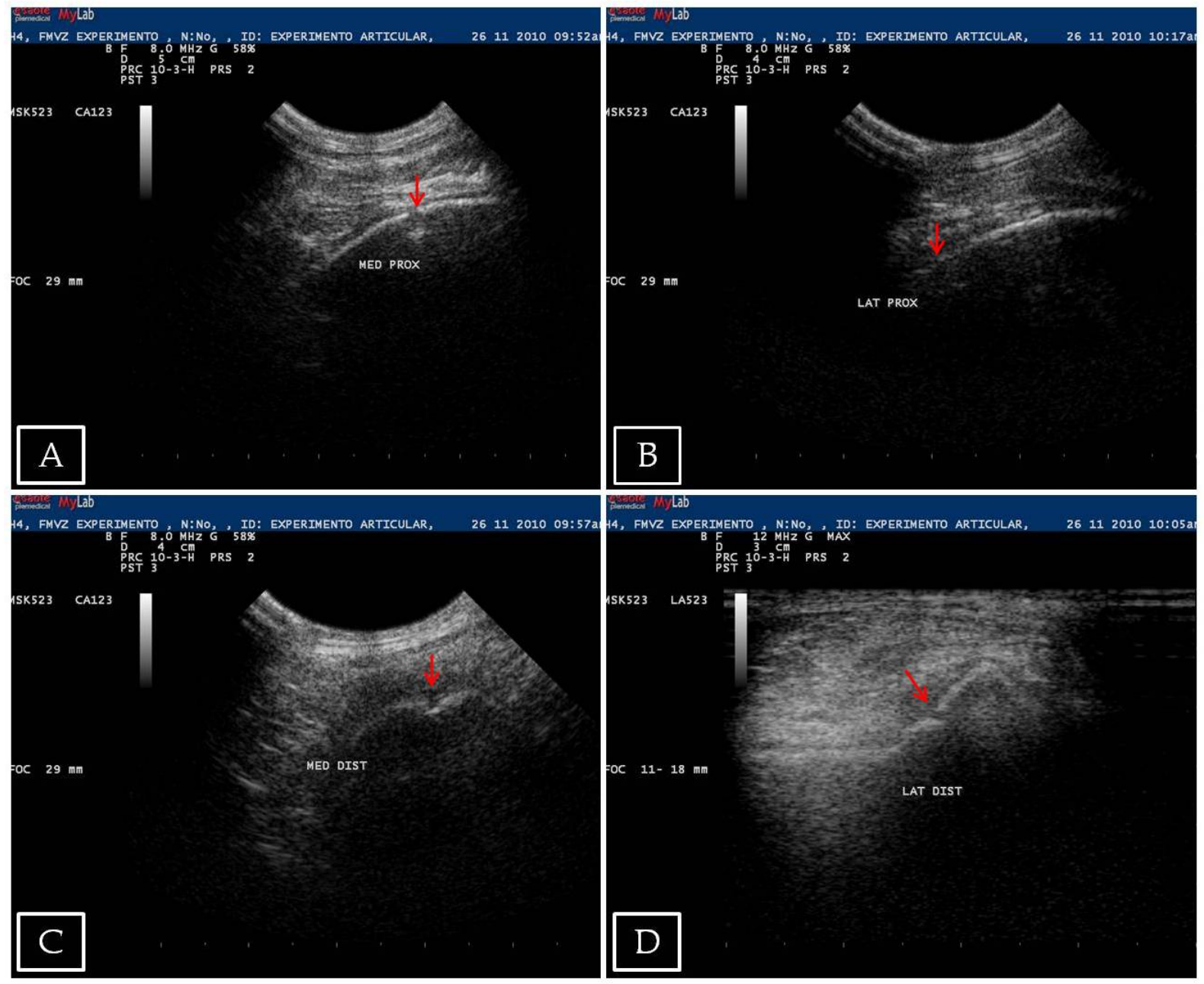

Figura 33 - Imagem ultrassonográfica da articulação femorotibiopatelar esquerda, 156 dias póscirúrgico. A) Imagem longitudinal do defeito subcondral proximal em côndilo medial (seta - biomaterial); B) Imagem longitudinal do defeito subcondral proximal em côndilo lateral (seta - biomaterial com as CTPDs humanas); C) Imagem longitudinal do defeito subcondral distal em côndilo medial (seta - CTPD humana); D) Imagem transversal do defeito subcondral distal em côndilo lateral (seta - controle)

$\mathrm{Na}$ figura 34, 231 após o procedimento cirúrgico, observamos arrasamento de todas as lesões apresentando um aspecto irregular da linha base. Visualizamos na figura 34B, a lesão lateral proximal preenchida por conteúdo hipoecogênico com discretos ecos puntiformes entremeados, sendo um provável tecido cartilaginoso em mineralização. Já, na figura 34D lesão lateral distal preenchida por conteúdo ecodenso, sem material hipoecogênico com provável ausência de tecido cartilaginoso e com exposição do osso subcondral. 


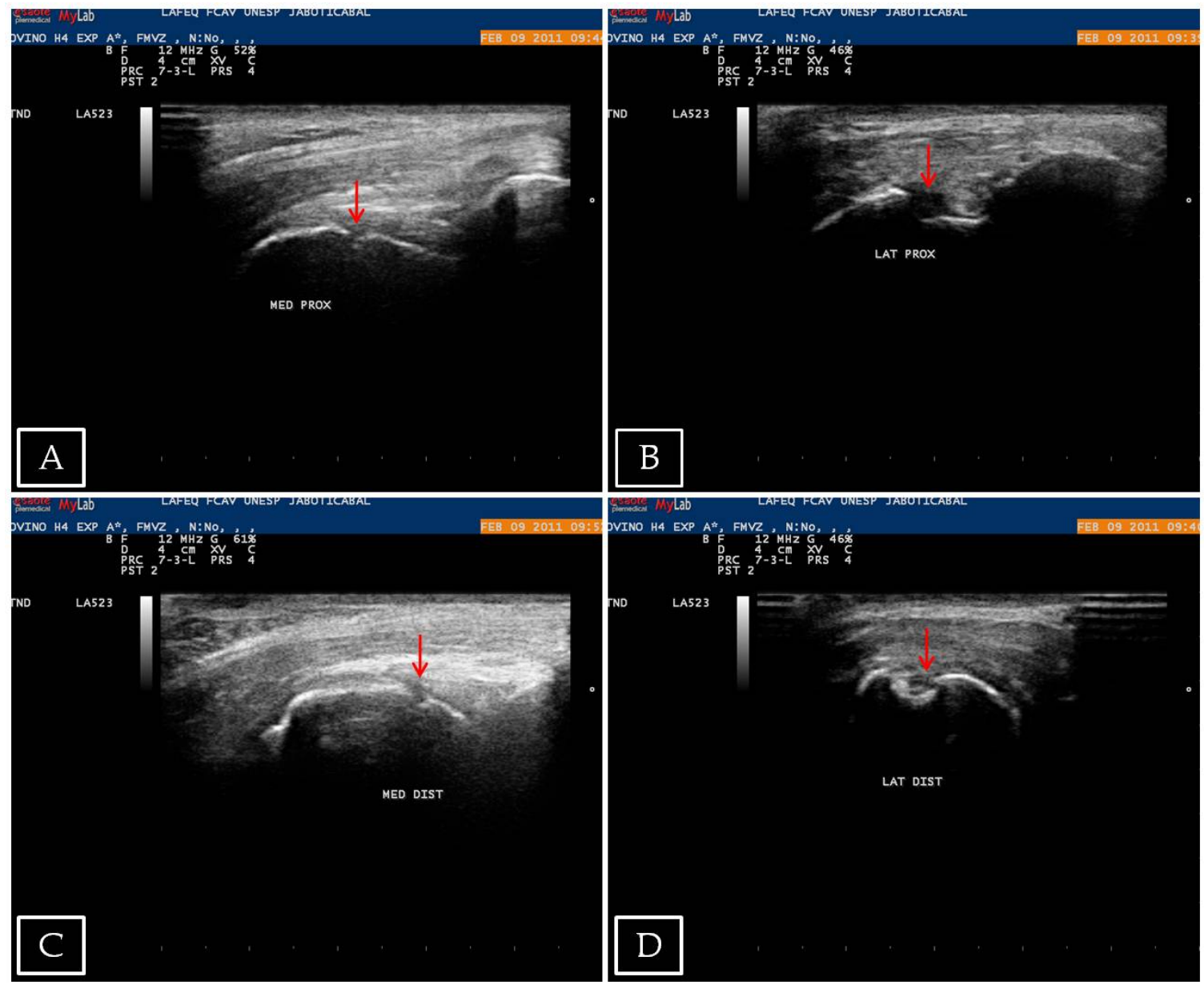

Figura 34 - Imagem ultrassonográfica da articulação femorotibiopatelar esquerda, 231 dias pós-cirúrgico. A) Imagem longitudinal do defeito subcondral proximal em côndilo medial (seta - biomaterial); B) Imagem longitudinal do defeito subcondral proximal em côndilo lateral (seta - biomaterial com as CTPDs humanas); C) Imagem longitudinal do defeito subcondral distal em côndilo medial (seta - CTPD humana); D) Imagem longitudinal do defeito subcondral distal em côndilo lateral (seta - controle)

Após 245 dias do procedimento cirúrgico, visualizamos no exame ultrassonográfico uma acentuada diminuição no diâmetro e na profundidade de todas as lesões com aspecto regular da linha base exceto na lesão lateral distal e em menor grau, na medial proximal (Figura 35). 


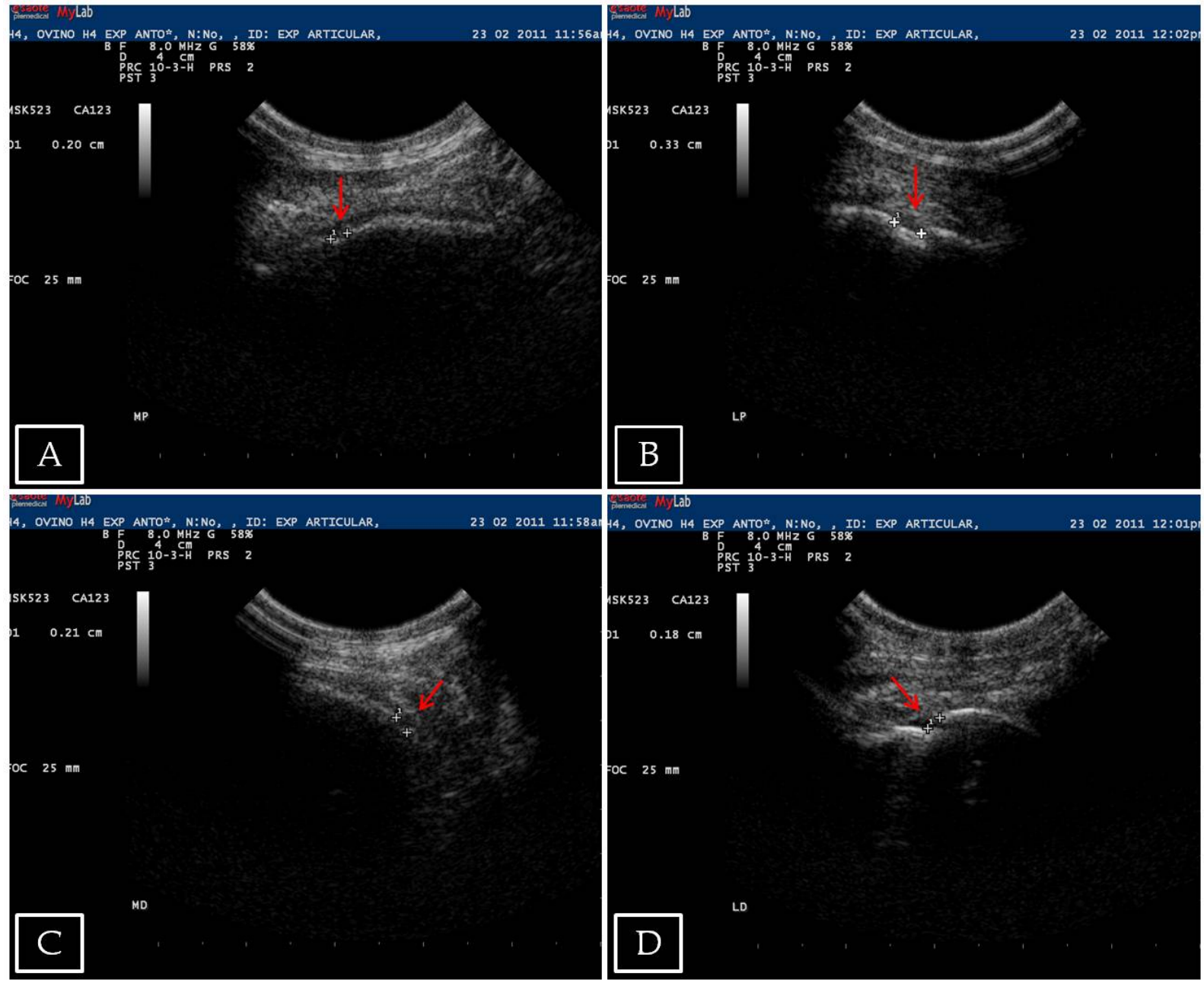

Figura 35 - Imagem ultrassonográfica da articulação femorotibiopatelar esquerda, 245 dias póscirúrgico. A) Imagem longitudinal do defeito subcondral proximal em côndilo medial (seta - biomaterial); B) Imagem longitudinal do defeito subcondral proximal em côndilo lateral (seta - biomaterial com as CTPDs humanas); C) Imagem longitudinal do defeito subcondral distal em côndilo medial (seta - CTPD humana); D) imagem longitudinal do defeito subcondral distal em côndilo lateral (seta) - controle

Os exames ultrassonográficos realizados após 311 dias do procedimento cirúrgico mostraram que todas as lesões possuem uma acentuada diminuição do diâmetro e da profundidade com aspecto regular da linha base, principalmente da lesão proximal do côndilo lateral, que se apresenta praticamente nivelada com o osso subcondral adjacente (Figura 36). 


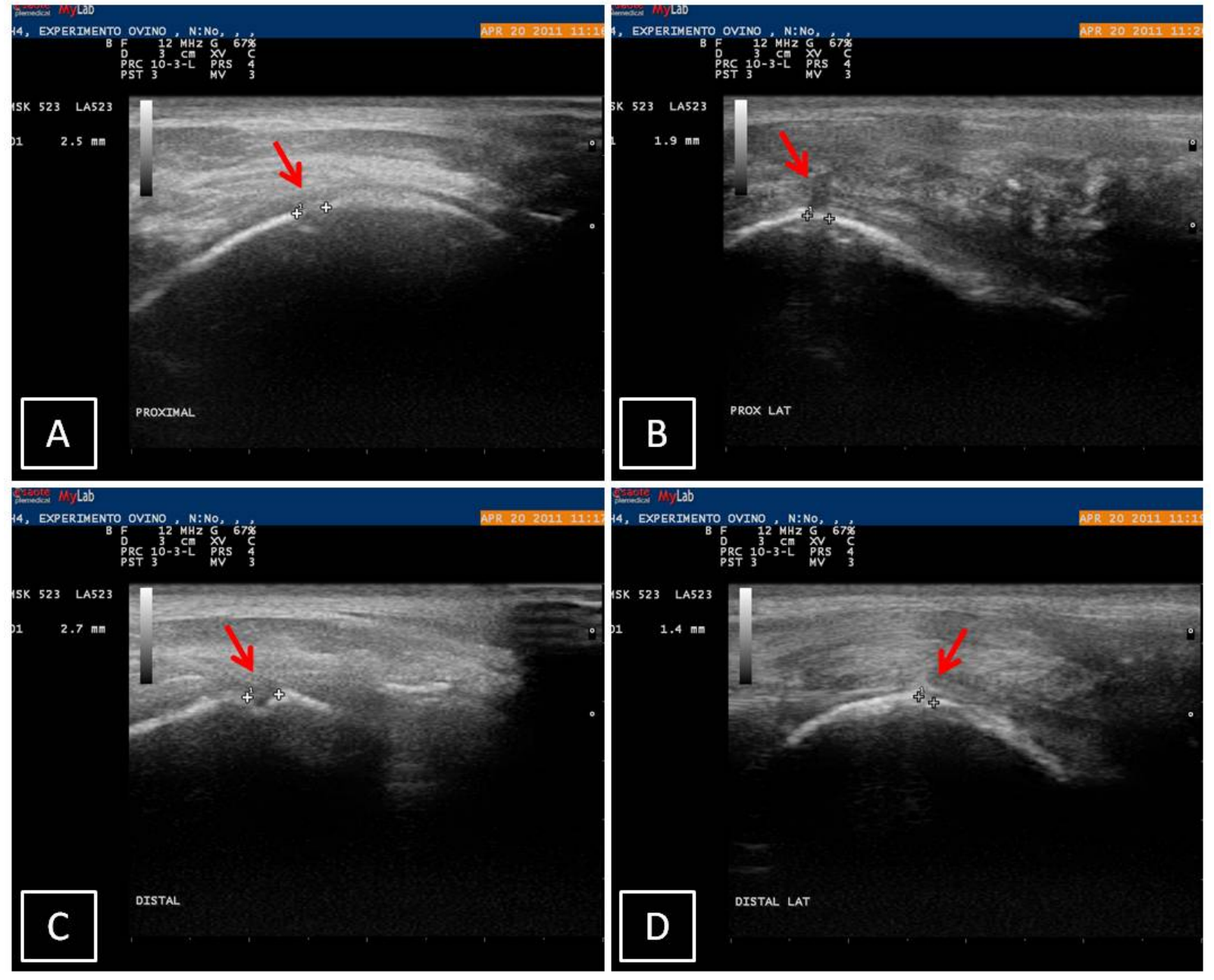

Figura 36 - Imagem ultrassonográfica da articulação femorotibiopatelar esquerda, 311 dias póscirúrgico. A) Imagem longitudinal do defeito subcondral proximal em côndilo medial (seta - biomaterial); B) Imagem longitudinal do defeito subcondral proximal em côndilo lateral (seta - biomaterial com as CTPDs humanas); C) imagem longitudinal do defeito subcondral distal em côndilo medial (seta - CTPD humana); D) Imagem longitudinal do defeito subcondral distal em côndilo lateral (seta - controle) 


\subsubsection{Exame de Artroscopia}

$\mathrm{Na}$ figura 37 apresentamos os resultados obtidos através de exames de artroscopia da articulação femorotibiopatelar esquerda, após 93 dias do procedimento cirúrgico. Observe no orificio proximal medial da femorotibiopatelar esquerda, local onde foi implantado o biomaterial, uma invaginação do tecido cicatricial com a presença de alguns pontos hemorrágicos (Figura 37A) e no local onde foi inserido o biomaterial associado à CTPD, orifício proximal lateral da articulação, uma área cicatricial no plano da superfície articular, discretamente irregular com uma coloração esbranquiçada similar a cartilagem adjacente (Figura 37B). Na figura 37C, temos o orifício distal medial e nele aplicamos apenas células e na artroscopia observamos uma área cicatricial de superfície irregular e retraída em relação ao plano articular, com coloração esbranquiçada e apresentando proliferações de aspecto viloso. Entretanto em $37 \mathrm{D}$, onde o orifício distal lateral foi utilizado como controle, observamos um área cicatricial de superfície irregular, retraída em relação ao plano articular, apresentando áreas hemorrágicas centrais e proliferação de aspecto viloso. 


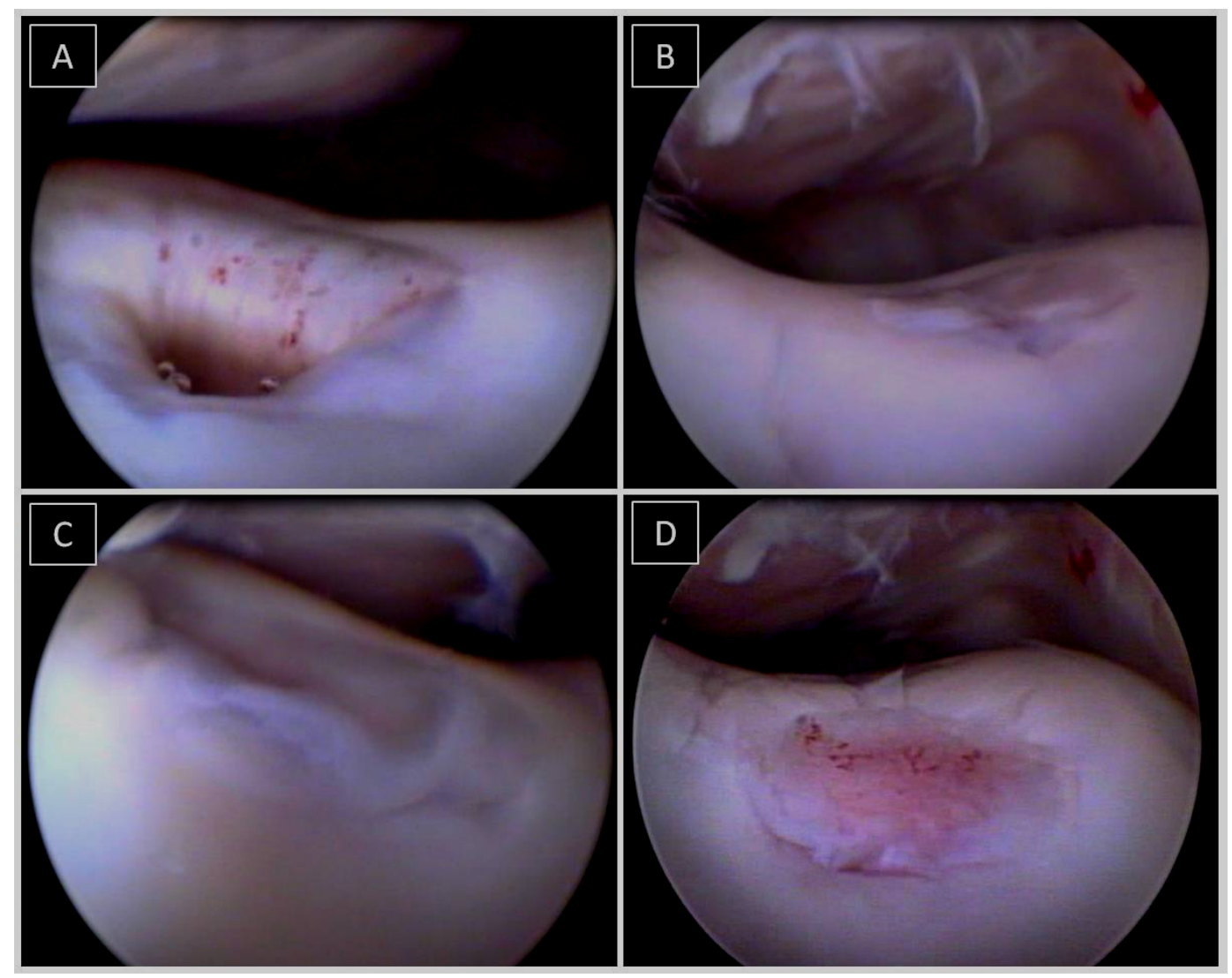

Figura 37 - Imagens artroscópicas da articulação femorotibiopatelar esquerda de ovino, destacando as diferentes regiões tratadas, após realização dos defeitos osteocondrais, aos 93 dias de pós-operatório. A) Trtamento com biomaterial; B) Biomaterial associado as CTPD humana; C) CTPD humana; D) Controle

Após 174 dias do procedimento cirúrgico, uma nova artrosocopia foi realizada e observamos que uma discreta diferença na invaginação do tecido cicatricial da lesão tratada com biomaterial com plano retraído em relação a superfície articular (Figura 38A); uma maior proliferação de aspecto viloso e ponto hemorrágico lateral no tratamento com as células (Figura $38 \mathrm{C}$ ) e ainda pudemos observar no controle pontos hemorrágicas na lateral (Figura 38D). 

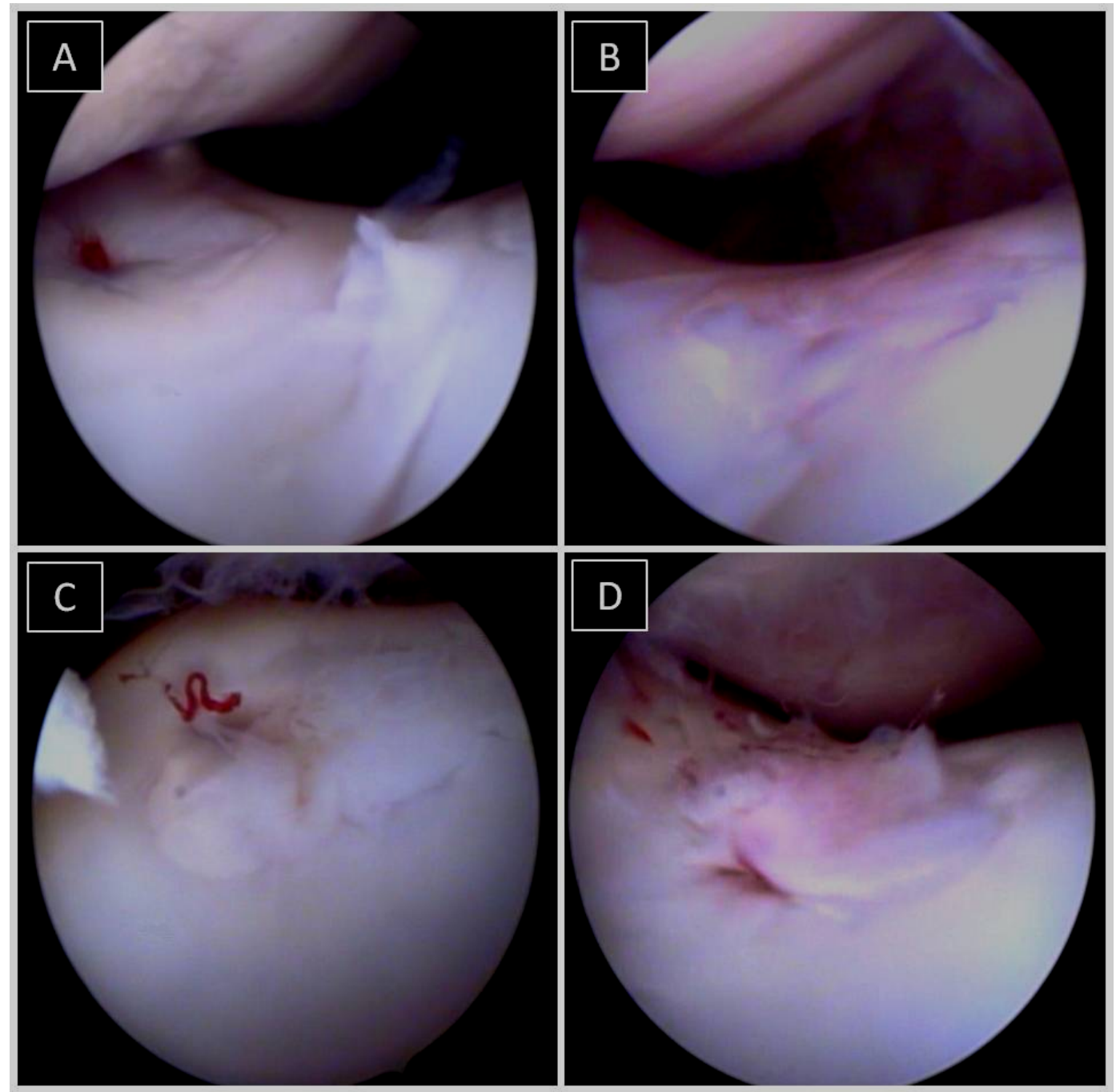

Figura 38 - Imagens artroscópicas da articulação femorotibiopatelar esquerda de ovino, destacando as diferentes regiões tratadas, após 174 dias da realização dos defeitos osteocondrais. A) Tratamento com biomaterial; B) Biomaterial associado as CTPDs humana; C) CTPD humana; D) Controle

$\mathrm{Na}$ artroscopia realizada após 280 dias do procedimento cirúrgico, pudemos observar uma invaginação do tecido cicatricial, com um plano discretamente retraído em relação ao plano da superfície articular e coloração esbranquiçada no orifício onde foi implantando apenas o biomaterial (Figura 39A).

O exame artroscópico do orifício proximal lateral da articulação femorotibiopatelar esquerda, local onde foi implantado o biomaterial associado a CTPD, apresentou uma área cicatricial no plano da superfície articular, discretamente irregular com uma coloração esbranquiçada similar a cartilagem adjacente e com pouca proliferação (Figura 39B). 
Observamos no orifício tratado apenas com células, uma área cicatricial de superfície irregular e retraída em relação ao plano articular de coloração esbranquiçada, com proliferação difusa de aspecto viloso também de coloração esbranquiçada (Figura 39C). No local do controle, vemos uma área cicatricial de superfície irregular, retraída em relação ao plano articular, com coloração esbranquiçada, proliferação difusa de aspecto viloso bem mais evidente comparando como exame anterior (Figura 39D).

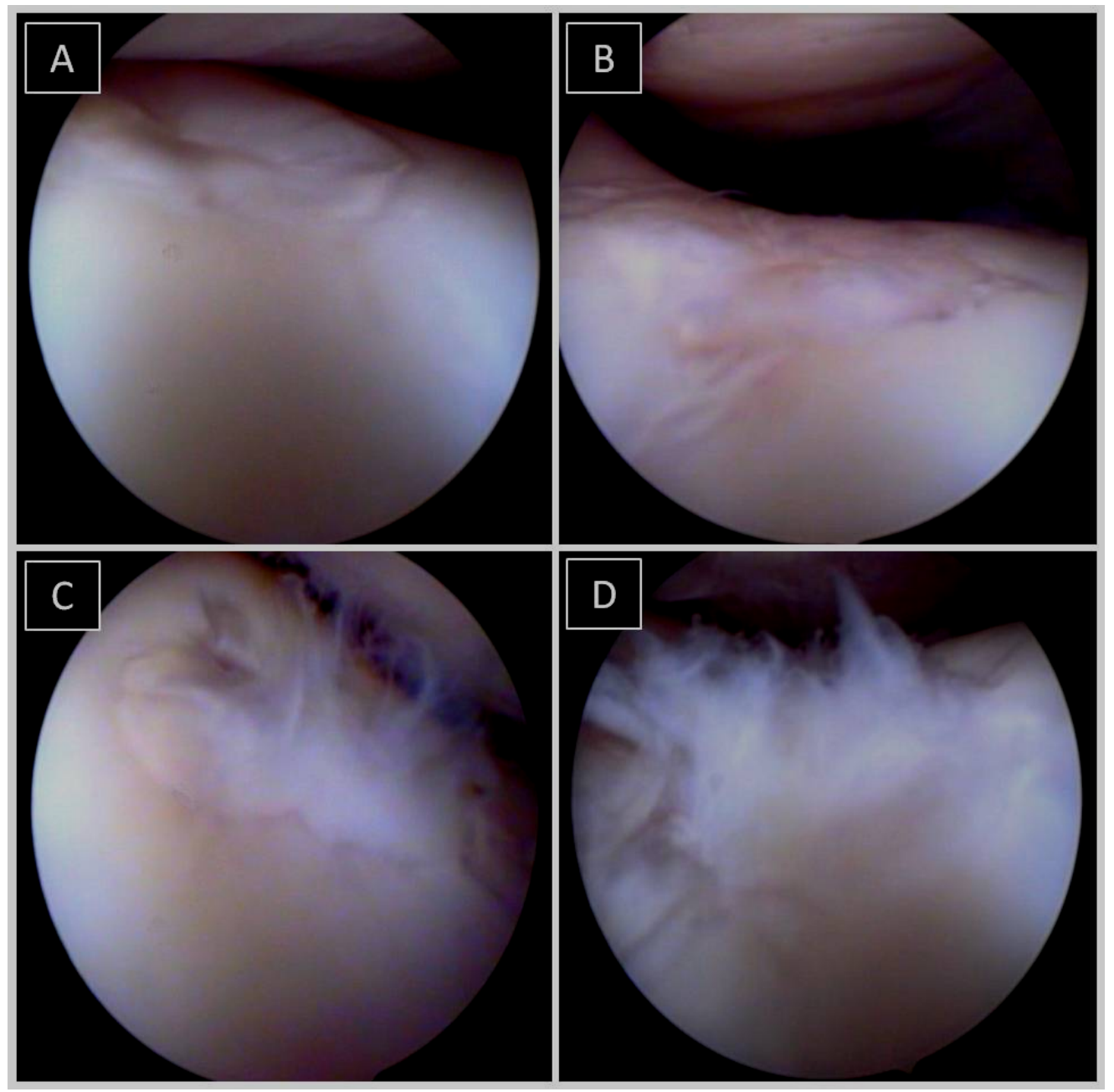

Figura 39 - Imagens artroscópicas da articulação femorotibiopatelar esquerda de ovino, destacando as diferentes regiões tratadas, após realização dos defeitos osteocondrais, após 280 dias do procedimento cirúrgico. A) Tratamento com biomaterial; B) Biomaterial associado as CTPD humana; C) CTPD humana; D) Controle 


\subsubsection{Exames Bioquímicos e Hemograma}

Todos os parâmetros dos hemogramas e análises bioquímicas séricas apresentaram-se dentro dos valores de normalidade.

\subsection{ANÁLISE HISTOLÓGICA DA ARTICULAÇÃO FEMOROTIBIOPATELAR DOS OVINOS NÃO TRATADOS SUBMETIDOS A DIFERENTES PROTOCOLOS DE DESCALCIFICAÇÃO}

Neste trabalho o procedimento de descalcificação óssea é um dos fatores limitantes e por isso, submetemos fragmentos de articulação femorotibiopatelar não tratados com o biomaterial a diferentes processos de descalcificação óssea bem como, ao metilmetacrilato. O material descalcificado foi submetido a rotinas histológicas e analisados por diferentes técnicas de coloração, visando achar o melhor método de descalcificação e conseqüentemente, analisar o material uma vez que, o primeiro procedimento de descalcificação testado e idealizado não se mostrou tão satisfatório.

\subsubsection{Análise histológica após descalcificação com EDTA A 10\%}

O material descalcificado com EDTA foi submetido a rotinas de histologia e diferentes colorações

\subsubsection{Coloração de HE}

O material submetido à técnica de descalcificação por EDTA submetido à coloração por HE demonstrou uma preservação das características dos tecidos.

$\mathrm{Na}$ figura 40, a cartilagem do sulco troclear femoral está demonstrada nas setas pretas da Figura 40A, B e foi caracterizada pela presença de 
condrócitos que são células ovaladas cercadas por matriz extracelulares e estão localizados em lacunas que podem envolver mais de um condrócito (setas pretas Figura 40C, D). Os osteócitos estão localizados na matriz das trabéculas ósseas (setas vermelhas - Figura 40 A, B, C, D).

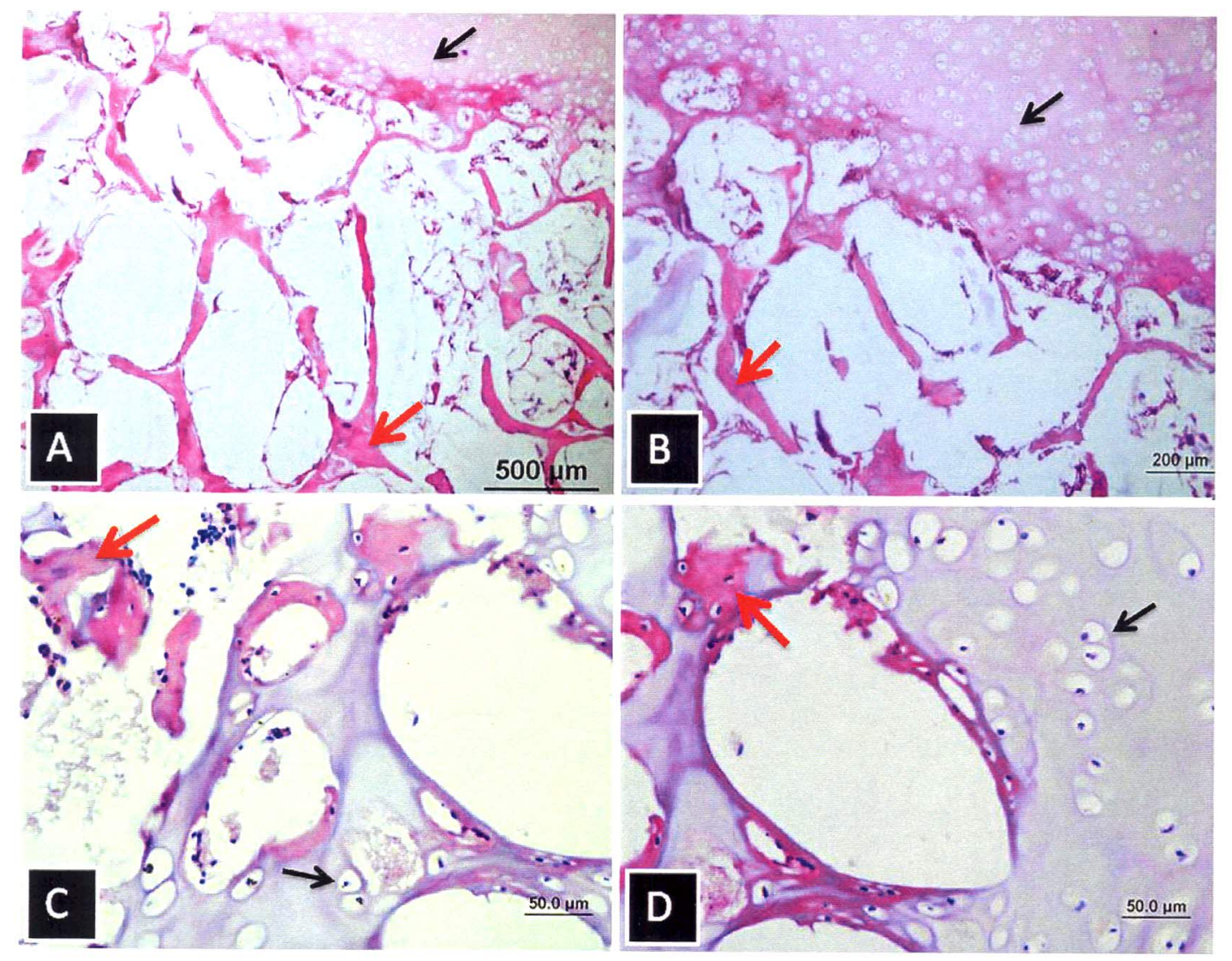

Figura 40 - Fotomicrografia dos tecidos cartilaginosos e conjuntivos do sulco troclear femoral submetidos à coloração de HE e visualizados por microscopia optica. A, B, C, D) Evidenciação das trabéculas ósseas por setas vermelhas; C, D) Condrócitos identificados no tecido cartilaginoso por setas pretas; Escala de barrras: A) $500 \mu \mathrm{m}$, B) $200 \mu \mathrm{m}$, C, D) $50 \mu \mathrm{m}$

\subsubsection{Coloração de Picrosírius}

A figura 41 representa os resultados obtidos na coloração de picrosírius utilizando o material descalcificado por EDTA. Note que o material submetido neste procedimento continha os orifícios da lesão proposta no projeto. Novamente observamos uma preservação das características dos tecidos.

$\mathrm{Na}$ figura 41A podemos observar o defeito ósseo induzido no sulco troclear femoral de acordo com o procedimento cirúrgico descrito no ítem 4.6 de materiais e métodos. A parte branca representa o local onde os tratamentos serão inseridos (*). 
A matriz cartilaginosa (seta preta - Figura 41B) é caracterizada pela presença de condrócitos, células ovaladas (seta preta - Figura 41C, D). Trabéculas ósseas também podem ser observadas (seta vermelha - Figura 41A, B, C, D).

A técnica de coloração de picrosírius é comumente utilizada para visualização do colágeno, como mostrado na figura 42.

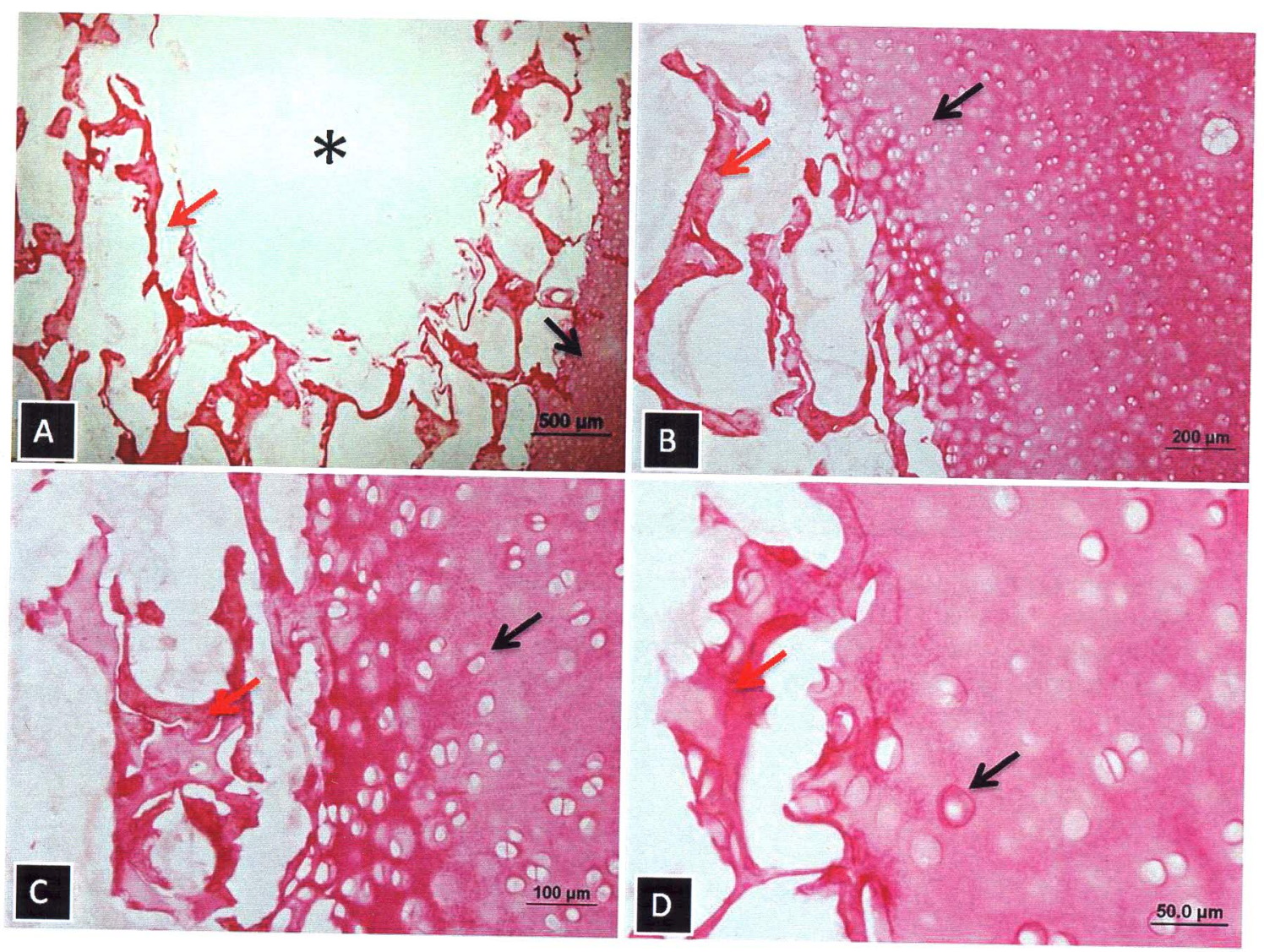

Figura 41 - Fotomicrografia dos tecidos cartilaginoso e conjuntivo do sulco troclear femoral submetido à coloração de picrosírius e visualizados por microscopia optica. A, B, C, D) Trabéculas ósseas identificadas por setas vermelhas e de um defeito osteocondral (*); C, D) Condrócitos identificados no tecido cartilaginoso. Escala de barras: A) $500 \mu \mathrm{m}$; B) $200 \mu \mathrm{m}$; C) $100 \mu \mathrm{m}$, D: $50.0 \mu \mathrm{m}$

A técnica de coloração de picrosírius é comumente utilizada para visualização do colágeno, como mostrado na figura 42. Na figura 42A observamos a cartilagem do sulco troclear caracterizada pela presença de células arredondadas, os condrócitos e as trabéculas ósseas evidenciadas na Figura 42C. Já, as fibras colágenas do tecido cartilaginoso podem ser observadas na figura 42B e D. 


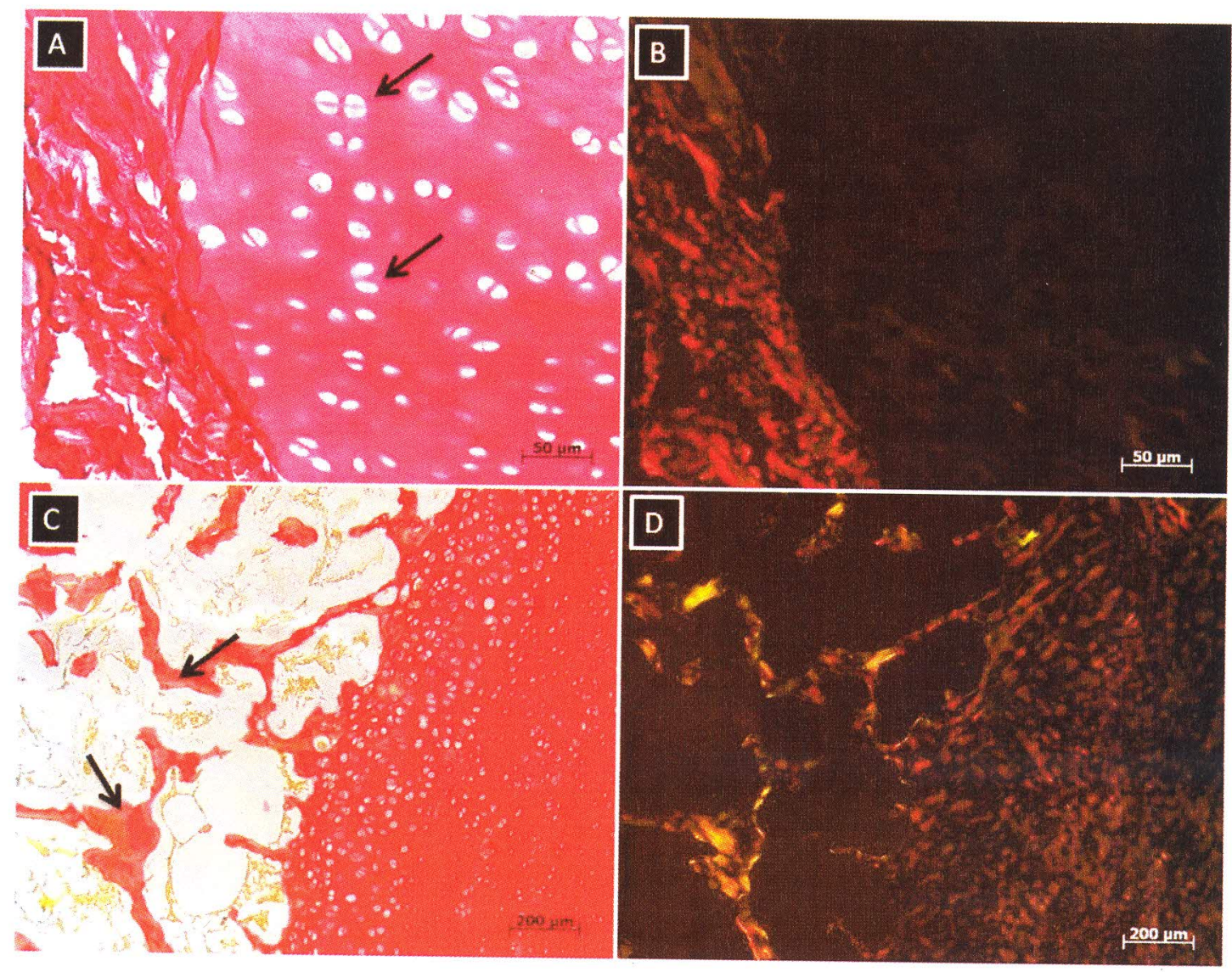

Figura 42 - Fotomicrografia dos tecidos cartilaginoso e conjuntivo do sulco troclear femoral submetidos à coloração de picrosírius. A, C) Cartilagem; B, D) Fibras colágenas presentes na cartilagem. Coloração: picrosírus. A, C) Imagens obtidas por microscopia óptica. B, D) Imagens obtidas por microscopia de polarização. Escala de barras: A, B) $50 \mu \mathrm{m}$; C, D) $200 \mu \mathrm{m}$

\subsubsection{Coloração de Azo-Carmim}

Na figura 43A mostramos defeito ósseo induzido no sulco troclear femoral da articulação femorotibiopatelar. As setas nas figuras 43B, C indicam presença da matriz cartilaginosa, constituída pelos condrócitos (setas - Figura 43D).

Como nas colorações anteriores, as estruturas dos tecidos analisados permaneceram preservadas após a descalcificação com EDTA. 


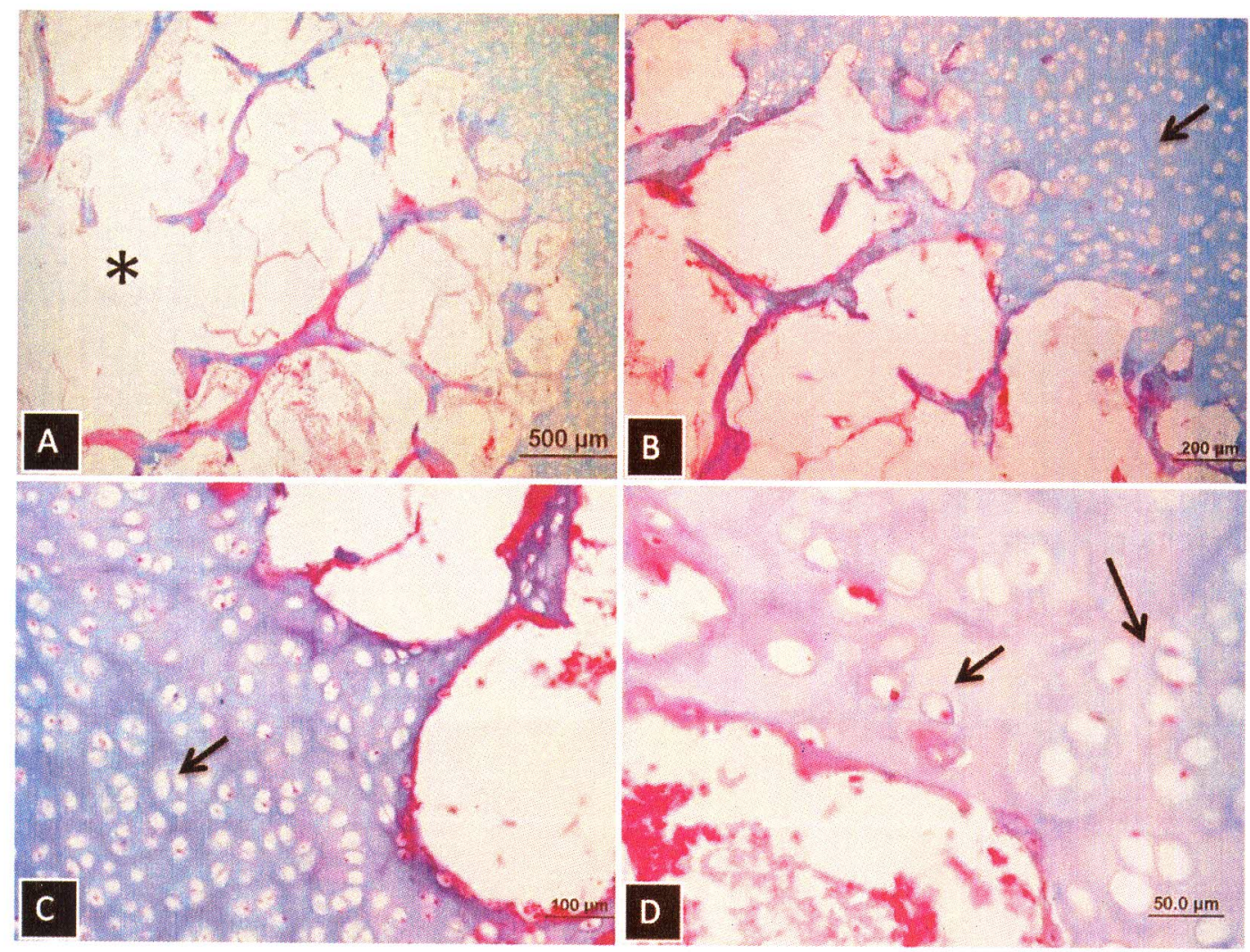

Figura 43 - Fotomicrografia do tecido cartilaginoso do sulco troclear femoral submetidos a coloração de azo-carmim e visualizados por microscopia óptica. A) Evidenciação do defeito ósseo; B, C) Matriz cartilaginosa; D) Condrócitos identificados no tecido cartilaginoso Escala de barras: A) $500 \mu \mathrm{m}$; B) $200 \mu \mathrm{m}$; C) $100 \mu \mathrm{m}$, D) $50 \mu \mathrm{m}$

\subsubsection{Análise histológica após descalcificação com solução Morse}

O material sem tratamento foi submetido a rotinas histológicas e diferentes colorações:

\subsubsection{Coloração de HE}

$\mathrm{Na}$ figura 44 apresentamos os resultados obtidos após coloração onde observamos que a descalcificação com solução de Morse preservou as características dos tecidos. A cartilagem do sulco troclear femural pode ser viualizada pela seta na Figura 44B e foi caracterizada pela presença de 
células condrócitos (setas - Figura 44C, D). Já, os osteócitos estão localizados na matriz das trabéculas ósseas e podem ser visualizadas pelas setas na figura 44A.

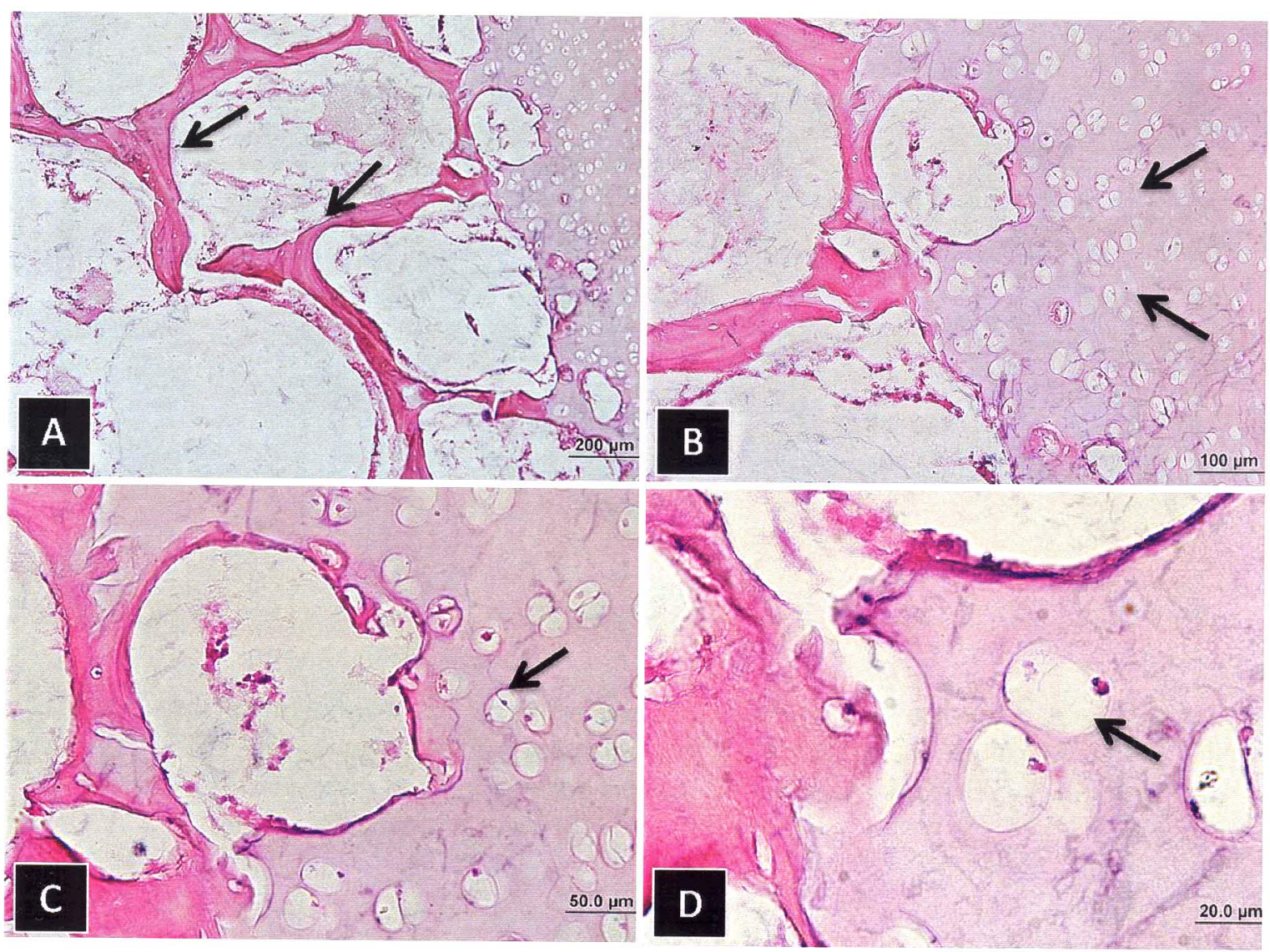

Figura 44 - Fotomicrografia dos tecidos cartilaginosos e conjuntivos do sulco troclear femoral submetidos à coloração de HE e visualizados por microscopia optica. A) Evidenciação das trabéculas ósseas por setas; C, D) Condrócitos identificados no tecido cartilaginoso por setas; Escala de barras: A) $200 \mu \mathrm{m}$; B) $100 \mu \mathrm{m}$; C) $50 \mu \mathrm{m}$; D) $20 \mu \mathrm{m}$

\subsubsection{Coloração de Picrosírius}

O sulco troclear femoral corado em picrosírius pode ser observado na Figura 45 A, B. Já, os condrócitos presentes no tecido cartilaginoso podem ser visualizados na figura $45 C, D$. 

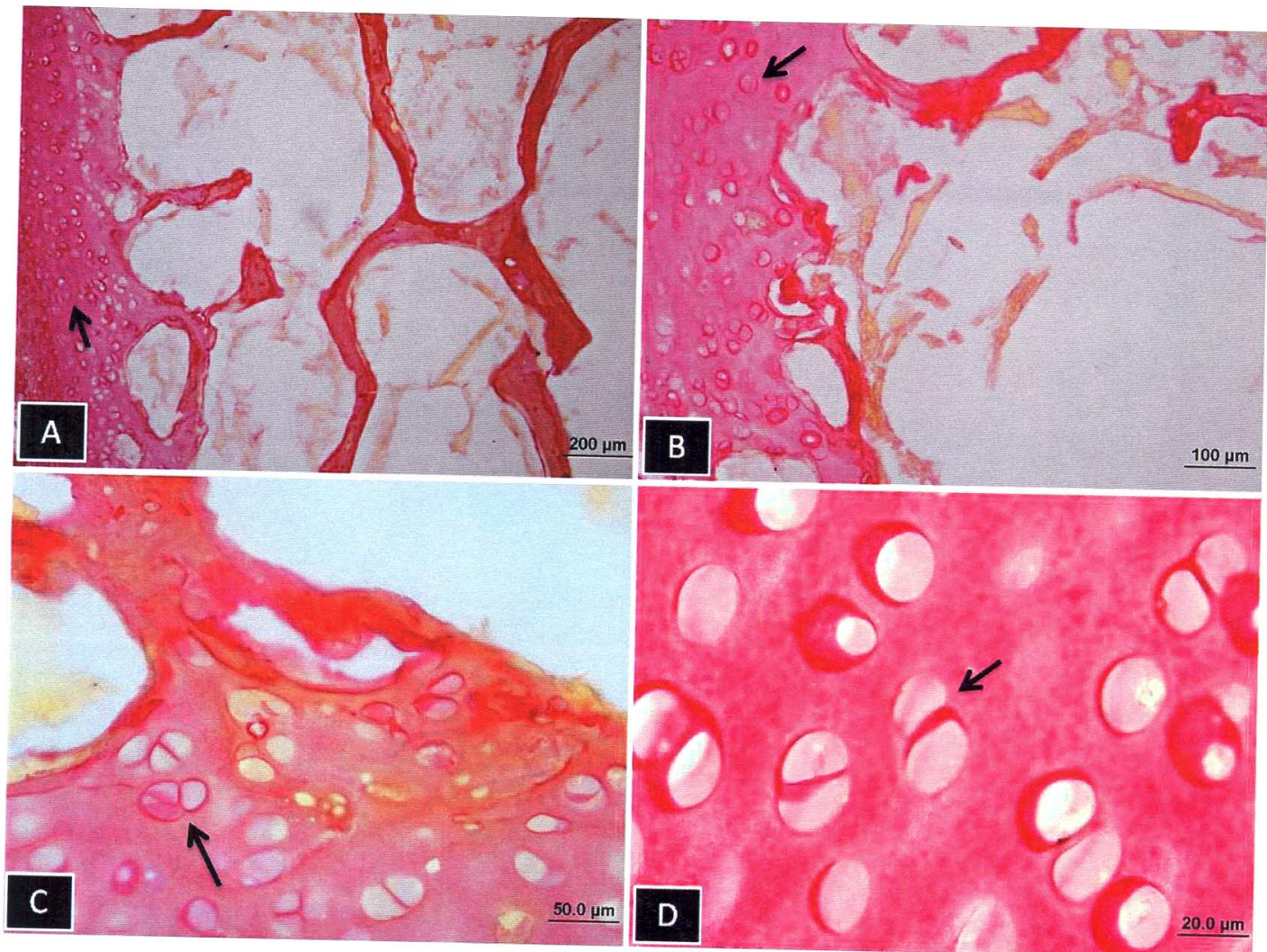

Figura 45 - Fotomicrografia do tecido cartilaginoso submetidos à coloração de picrosírius e visualizados por microscopia optica.. A, B) matriz cartilaginosa; C, D)

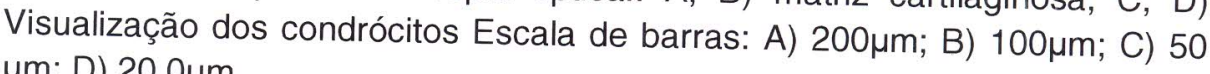
$\mu \mathrm{m}$; D) $20.0 \mu \mathrm{m}$

\subsubsection{Coloração de azo-carmin}

Com esta coloração podemos observar o tecido cartilaginoso (setas pretas Figura 46A,B) e as trabéculas ósseas (setas vermelhas- Figura 46A,B). Nas figuras $46 C$, D visualizamos a presença dos condrócitos no tecido cartilaginoso. Desta forma, podemos dizer que a técnica de descalcificação utilizada não alterou as características dos tecidos. 


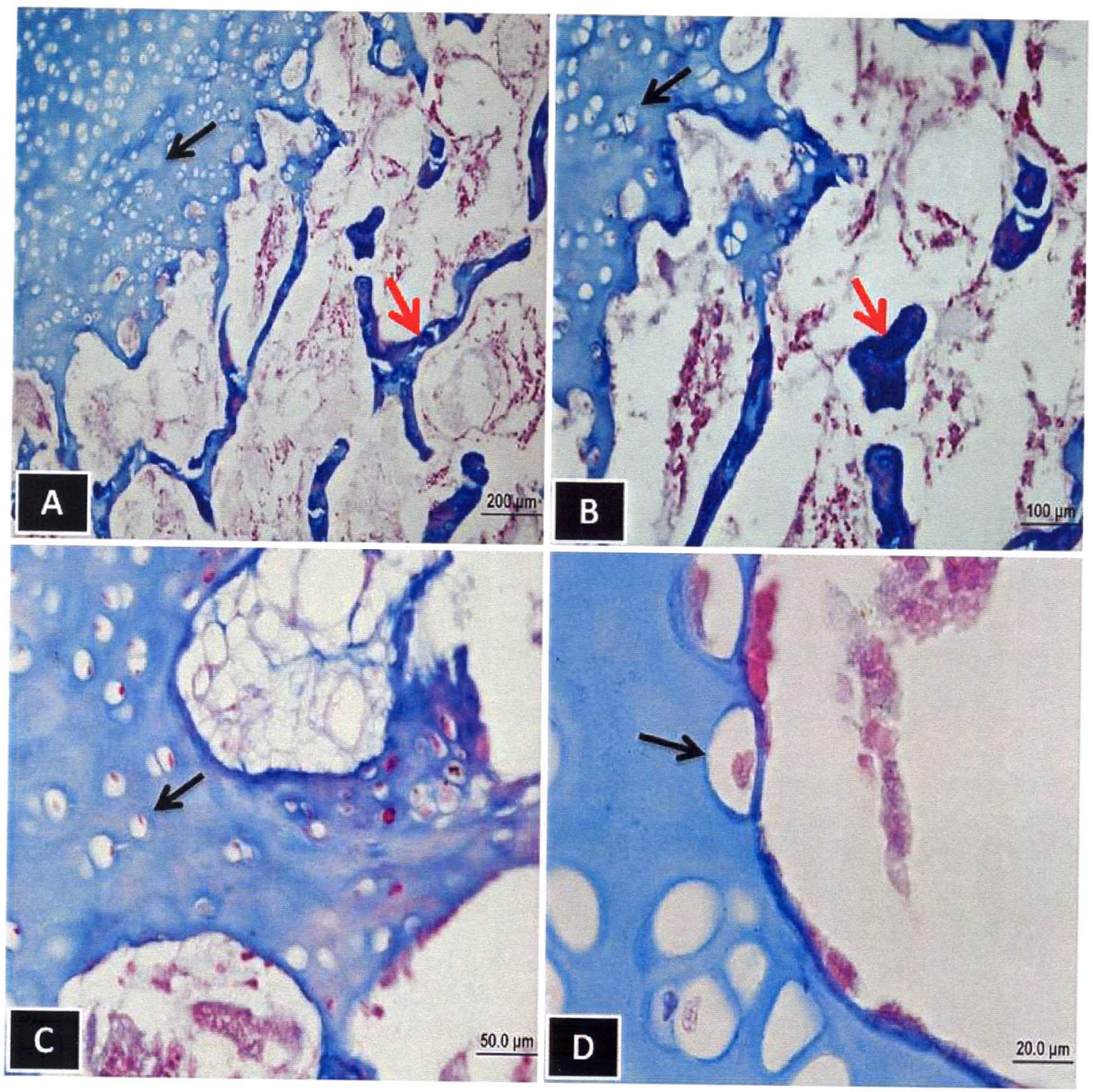

Figura 46 - Fotomicrografia dos tecidos cartilaginoso e conjuntivo do sulco troclear femoral submetidos a coloração de azo-carmim e visualizados por microscopia óptica. A, B) cartilagem identificada por setas pretas; A, B,) trabéculas ósseas identificadas por setas vermelhas; C, D) condrócito. Escala de barras: A) $200 \mu \mathrm{m}$; B) $100 \mu \mathrm{m}$; C) $50 \mu \mathrm{m}$, D) $20 \mu \mathrm{m}$

\subsubsection{Análise histológica após descalcificação óssea utilizando a solução Safe Controllable Decalcifier Gold - RDO}

A utilização de descalcificador foi baseada na rapidez do processo e após a descalcificação o material foi submetidos a rotinas histológicas e diferentes colorações. 


\subsubsection{Coloração de HE}

Apesar deste método de descalcificação ter ocorrido em tempo menor que os outros este método não é indicado para nós, pois os resultados obtidos não favoreceram a preservação das características estruturais dos tecidos analisados (Figura 47)



Figura 47 - Fotomicrografia do tecido cartilaginoso em diferentes focos submetidos a coloração de HE e visualizados por microscopia óptica. Escala de barras: A) $500 \mu \mathrm{m}$; B) $200 \mu \mathrm{m}$; C) $100 \mu \mathrm{m}$; D) $50 \mu \mathrm{m}$

\subsubsection{Coloração de Picrosírius}

Como na coloração de HE, as estruturas características dos tecido analisados não foram preservadas (Figura 48). 

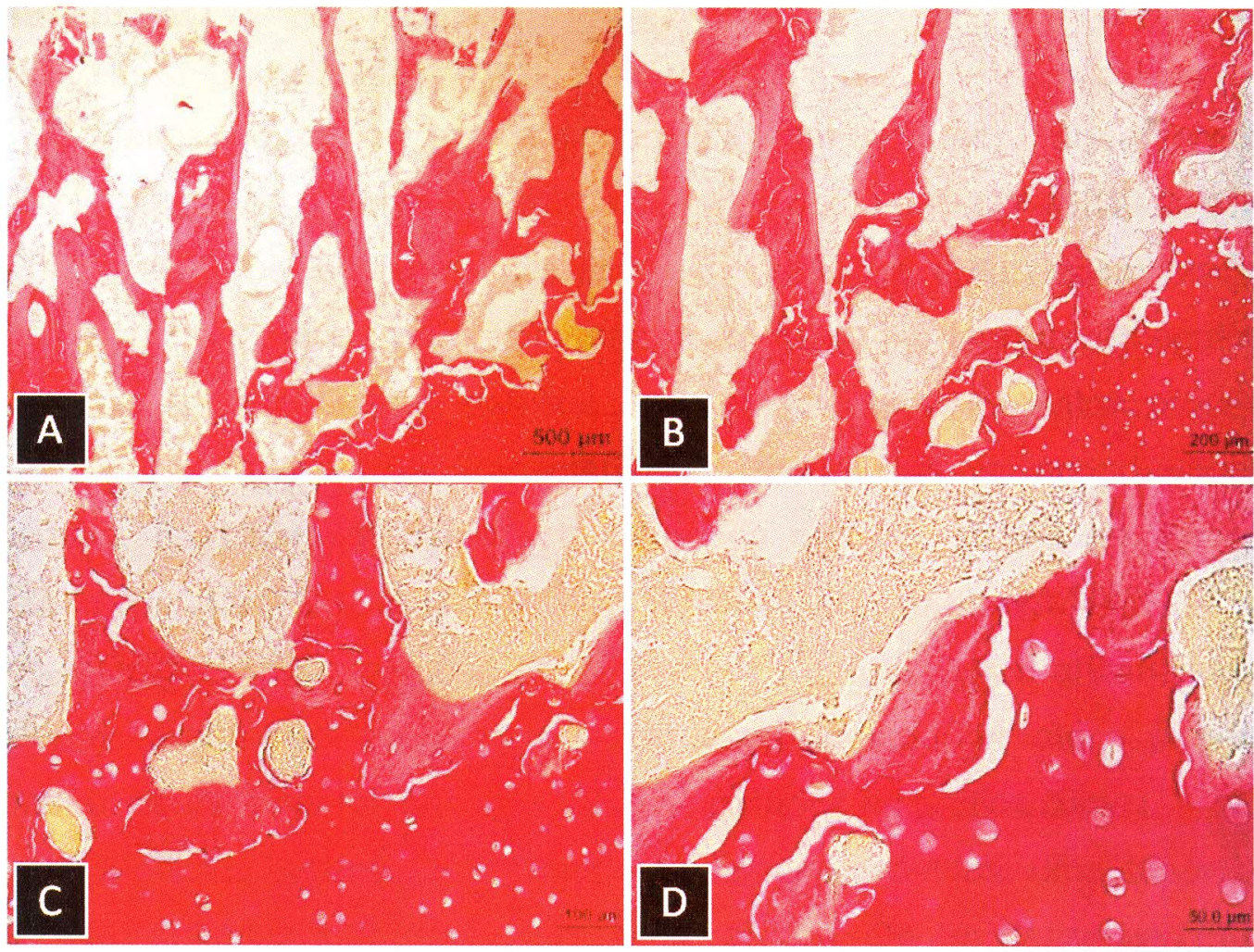

Figura 48 - Fotomicrografia do tecido cartilaginoso em diferentes focos por coloração de picrosírius. Imagem obtida por microscopia óptica. Escala de barras: A) $500 \mu \mathrm{m}$; B) $200 \mu \mathrm{m}$; C) $100 \mu \mathrm{m}$; D) $50 \mu \mathrm{m}$ 


\section{DISCUSSÃo}

Defeitos ou danos na cartilagem articular ocorrem frequentemente como resultados de trauma, tumores e doenças como a AO (WAKITAIN et al., 1998). Devido à baixa taxa de mitose dos condrócitos, a cartilagem articular não é capaz de regenerar-se totalmente, de forma que a degradação contínua acaba ocasionando amplos defeitos. Atualmente, os tratamentos propõem medicamentos, artroplastia, transplante de condrócitos ou econdrectomia, entretanto, qualquer um deles está longe de produzir efeitos amplamente satisfatórios (JOHNESON, 1986; WAKITAIN et al., 1998; VACHON et al., 1991). Adicionalmente, estudos de regeneração da cartilagem articular estão sendo realizados com maior frequência, ainda sem dados, até o presente momento, de tratamentos que possam ser utilizados na prática clínica.

A Medicina regenerativa surgiu nos últimos anos como uma esperança para tratar doenças ainda sem tratamento efetivo. Dentro desse cenário, o interesse pelas células-tronco tem aumentado significativamente (NOLAN et al., 2008). Tanto as terapias celulares como as bioengenharias atuam na medicina regenerativa, procurando melhorar a capacidade da regeneração de tecidos (OLIVEIRA et al., 2010). Neste trabalho propusemos um modelo de terapia celular utilizando as CTPD humana, associadas ou não a um biomaterial constituído de HA e quitosano, para poder observar a interação entre os mesmos e também avaliar a regeneração do tecido cartilaginoso, para futuramente ser testado como terapia em humanos no tratamento de lesões da cartilagem articular. Essa associação foi testada in vitro e in vivo, através de avaliação clínica, laboratorial e por imagem.

Dentre os métodos de avaliação da interação das células com o biomaterial in vitro, a técnica de MEV se mostrou eficiente e importante. A técnica de MEV permite uma avaliação detalhada do biomaterial, com a visualização dos suportes porosos onde as células se aderem (OSATHANON et al., 2008; YU et al., 2008), a observação da proliferação endotelial (YU et al., 2009), e a visualização da morfologia de superfície, com ou sem células ou proteínas de matriz (YU et al., 2008; MALAFAYA; REIS, 2009). Qiet al.(2011) estudaram as MSC isoladas da membrana sinovial de ratos inseridas em um biomaterial constituído de quitosana-alginato, com 
características porosas. Depois de duas semanas, através da MEV, foi observado que as células ficaram aderidas a esse biomaterial e apresentaram acentuada proliferação. Isto mostra que o biomaterial forneceu um microambiente favorável para suportar a proliferação condrogênica e a diferenciação celular. De acordo com os nossos resultados, podemos inferir que o biomaterial composto por HA e quitosana também apresentaram essas características favoráveis as CTPD humana, visto que o mesmo mostrou boa aderência celular evidenciada através da MEV e da histologia in vitro. Além disso, foi possível verificar sua estrutura e a perfeita compatibilidade para o ambiente celular, onde verificamos a presença de células vivas após um mês de incubação in vitro. Esses resultados nos animaram para ingressar na área terapêutica.

Os modelos animais são muito importantes para o delineamento experimental, permitindo o melhor conhecimento da fisiologia, da etiopatogenia das doenças, da ação dos medicamentos ou dos defeitos ocasionados pelas cirurgias (FERREIRA; HOCHMAN; BARBOSA, 2005). Nos últimos anos, modelos animais têm sido utilizados em estudos pré-clínicos com abordagens mecânicas similares as da articulação femorotibiapatelar em humanos. Desta maneira, em nosso trabalho escolhemos o ovino como modelo animal, pois, devido as suas particularidades, ele é muito utilizado em ensaios pré-clínicos na ortopedia (MANGGOLD et al., 2002; MURPHY et al., 2003; XIMIN GUO et al., 2004; D MRUGALA et al., 2008; SCHAGEMANN et al., 2009; TAPPER et al., 2008).

O procedimento cirúrgico para criar um defeito ostecondral foi estabelecido visando futuramente estudar a OA. Esse procedimento foi de fácil realização e sem nenhuma complicação pós-operatória, podendo ser considerado como adequado para essa finalidade.

As CTPD foram escolhidas em função de trabalhos recentes demonstrando que a polpa dentária humana é uma fonte de células-tronco mesenquimais com possibilidades terapêuticas promissoras. Durante o cultivo celular, as CTPD humanas apresentam características morfológicas semelhantes a fibroblastos alongados, fusiformes, pontiagudas, com núcleo grande e central, tipicamente encontrado em outras células-tronco mesenquimais (GRONTHOS et al., 2000; ZUCK et al., 2001; KERKIS et al., 
2006). Essas mesmas características foram observadas nas CTPD humanas isoladas e caracterizadas pelo nosso grupo e que foram usadas nesse trabalho.

Em outro estudo realizado, foram injetadas CTPD humana, em ratos, com pó de HA e fosfato tricálcio, observando a formação de osso, sendo confirmado que as células de polpa dentária humana podem ser utilizadas na regeneração de tecidos danificados (OTAKI et al., 2007). Além disso, estudos usando CTPD humanas em modelos animais demonstraram a capacidade de enxerto dessas células sem sinais de rejeição (KERKIS et al., 2008), mesmo sem terapia imunossupressora. O mesmo foi observado em nosso estudo, visto que não houve nenhum sinal de rejeição no ovino que recebeu as células, também sem terapia imunossupressora. Esses resultados foram comprovados clinicamente e através dos exames laboratoriais, radiológicos, ultrassonográficos e artroscópicos realizados no decorrer do trabalho. Ainda através desses exames, principalmente em decorrência dos resultados das artroscopias, houve uma melhora macroscópica aparente nos dois orifícios que receberam o biomaterial. Os mesmos resultados foram observados através dos exames de ultrassonografia, onde inicialmente foi vista uma irregularidade de formato côncavo em osso subcondral nas porções proximal e distal do côndilo femoral, preenchidas por um conteúdo hipoecogênico, sendo que no último exame observamos uma acentuada diminuição do tamanho e da profundidade das lesões com aspecto regular da linha base. Com os exames radiográficos, observamos as lesões criadas e a correta inserção do biomaterial na lesão.

Em tempo, apesar da artroscopia ser um procedimento invasivo, as complicações decorrentes da mesma não são frequentes e a incidência de complicações graves pode equivaler a menos de 1\% (PEREIRA, 2002). Neste trabalho, o exame artroscópico foi utilizado para analisar a reparação dos defeitos osteocondrais em diferentes momentos, pós-tratamento, com maior precisão das imagens por se tratar da visualização direta dos locais das lesões.

No orifício tratado apenas com biomaterial, observamos que a invaginação diminuiu, ficando o mesmo menos profundo em relação ao plano da superfície articular. No orifício que continha o biomaterial associado às 
células, também houve melhora, ficando este mais plano com a superfície articular e apresentando um melhor aspecto, semelhante ao de um tecido cartilaginoso. Já nos dois orifícios que não receberam o biomaterial, um tratado apenas com CTPD e outro sem nenhum tratamento, foram observados resultados semelhantes. Em ambos 0 aspecto viloso foi intensificado, ficando a profundidade do orifício aparentemente preenchida pelos vilos, mostrando que talvez só a presença das células não seja suficiente para reconstruir eficientemente a lesão.

Ainda no orifício que só recebeu a infusão de CTPD, deixamos as CTPDs pausarem por aproximadamente 6 minutos, pois segundo Koga et al. (2008), as MSC de liquido sinovial em suspensão aderiram mais de $60 \%$ promovendo a regeneração da cartilagem após decorridos 10 minutos. Aparentemente, o mesmo aconteceu com nosso modelo animal, evidenciado através do exame de artroscopia.

Com relação às técnicas histológicas, dos métodos de descalcificação óssea e da inclusão do MMA nos ossos, no biomaterial associado ou não as CTPD, várias técnicas foram testadas com intuito de padronizar a melhor condição para a avaliação da terapia in vivo e também testar as técnicas de colorações com o biomaterial.

Com relaçao aos protocolos de descalcificação, obsevamos que os que preservaram melhor as estruturas dos tecidos foram o material descalcificado pelo EDTA e pela solução morse, sendo que o primeiro descalcificador demorou menos tempo. Já o descalcificador RDO, apesar de ser considerado rápido, interferiu nos resultados, sem preservar totalmente as estruturas dos tecidos e dificultou a retirada do execesso de parafina das lâminas. Na inclusão do material no MMA, verificamos que a técnica foi rápida, porém inviável, pois não foi possível realizar muitos cortes do material incluído nesse processo, pois dificulta a penetração dos corantes no material.

As colorações realizadas foram adequadas, pois conseguimos evidenciar os tecidos e estruturas constituintes dos mesmos, lembrando que cada técnica de coloração possui as suas particularidades.

De acordo com os resultados obtidos nesse trabalho podemos acreditar que as CTPD humanas apresentam um perfil potencialmente relevante para regeneração de tecidos, em especial no modelo de cartilagem, 
inclusive podendo ser usadas entre indivíduos diferentes, no nosso caso entre espécies diferentes, sem, entretanto necessitarem de uma terapia imunossupressora, o que muitas vezes inviabiliza o processo terapêutico. Ainda, a aplicação das células-tronco associadas ao biomaterial aparentemente potencializou a ação regenerativa das CTPD, fornecendo um suporte adequado para a acomodação e possível diferenciação celular resultando na melhora do tecido lesionado, sendo, portanto a estratégia ideal para o tratamento. Nossos dados ainda serão checados microscopicamente, aplicando os procedimentos histológicos que foram testados e padronizados nesse trabalho, para que, então, a melhora histológica possa ser confirmada. 


\section{CONCLUSÕES}

De acordo com os resultados obtidos nesse trabalho podemos concluir que:

- O biomaterial foi compatível e não tóxico as CTPDs in vitro, permitindo o fluxo de cultura e mantendo assim, a viabilidade das células.

- Ainda nas análises in vitro, podemos dizer que apenas uma porcentagem de células não aderiu ao biomaterial, mas que o número de células aderidas foi adequado quando realizamos contagem após 24 horas de cultivo. 0 mesmo comportamento foi observado nas MEV.

- O procedimento cirúrgico proposto no trabalho foi adequado ao nosso estudo, não produzindo risco de morte ao animal e permitindo a avaliação clínica e o acompanhamento dos exames de imagem com facilidade.

- Em relação ao monitoramento do tratamento, podemos dizer que o exame artroscópico foi eficiente e adequado ao nosso estudo nos permitindo uma boa visualização dos resultados obtidos no tratamento apesar de ser minimamente invasivo. Já, os exames radiológicos não nos permitiram essa visualização dos resultados

- Apesar do descalcificante rápido, RDO proporcionar uma descalcificação bem mais rápida que os outros métodos, ele não foi adequado para as nossas análises histológicas, pois, o mesmo não preservou as características do tecido.

- O metilmetacrilato também não foi um método eficiente para nós uma vez que - número de cortes obtidos neste procedimento é inferior as nossas necessidades e ainda neste procedimento a incorporação dos corantes é dificultada. 
- Aparentemente o tratamento das lesões utilizando o biomaterial e o biomaterial associados as CTPDs foi mais eficiente que o tratamento feito apenas com as CTPDs. 


\section{REFERÊNCIAS}

ABHIJIT, M.; BHOSALE; JAMES, B. Articular cartilage: structure, injuries and review of management. Richardson British Medical Bulletin, v. 87, p. 7795, 2008.

AHSAN, T.; NEREM, R. M. Bioengineered tissues: the science, the technology, and the industry. Orthodontics and Craniofacial Research, v. 8, p. 134-140, 2005.

ALTMAN R, ASCH E, BLOCH D, BOLE G, BORENSTEIN D, BRANDT K, et al. Development of criteria for the classification and reporting of osteoarthritis. Classification of osteoarthritis of the knee. Diagnostic and Therapeutic Criteria Committee of the American Rheumatism Association. Arthritis \& Rheumatist. v.8, n.29, p. 1039-1049, 1986.

ANSELME, K. Osteoblast adhesion on biomaterials. Biomaterials, v. 21, n. 7, p. $667-681,2000$.

AROSARENA, O. Tissue engineering. Current opinion in otolaryngology and head and neck surgery, v. 13, p. 233-241, 2005.

BARBANTI, S. H.; ZAVAGliA, C. A. C.; DUEK, E. A. R. Polímeros bioreabsorvíveis na engenharia de tecidos. Polímeros: Ciência e Tecnologia, v. 15, n. 1, p. 13-21, 2005.

BIANCO, P.; KUZNETSOV, S. A.; RIMINUCCI, M.; ROBEY, P. G. Postnatal skeletal stem cells. In: Methods in Enzymology, 419: adult stem cells. p. 117$148,2006$.

BOELONI, J. N.; OCARINO, N. M.; MELO, A. B.; SILVA, J. F.; CASTANHEIRA, P.; GOES, A. M.; SERAKIDES, R. Dose-dependent effects of triiodothyronine on osteogenic differentiation of bone marrow mesenchymal stem cells in female rats. Hormone Research, v. 72, p. 88-97, 2009. 
BOYAN, B. D.; HUMMERT, T. W.; DEAN, D. D.; SCHWARTZ, Z. Role of material surfaces in regulating bone and cartilage cell response. Biomaterials, v. 17, n. 2, p. 137-146, 1996.

BUCKWALTER, J. A.; MANKIN, H. J. Articular cartilage: tissue design and chondrocyte-matrix interactions. Instructional Course Lectures. v. 47, p. 477-486, 1998.

CAPLAN, A. I. Mesenchymal stem cells and gene therapy. Clinical Orthopedics. Tissue Engineering, v. 11, p. 1198-1211, 2005.

CAPLAN, A. I.; BRUDER, S. P. Mesenchymal stem cells: building blocks for molecular medicine in the 21 st century. Trends in Molecular Medicine, v. 7,p. 259-264, 2001.

CHEN, G. Q.; WU, Q. The application of polyhydroxyalkanoates as tissue engineering materials. Biomaterials, v. 26, n. 33, p. 6565-6578, 2005.

CHEN, Y. G.; MENG, A. M. Negative regulation of TGF-beta signaling in development. Cell Research, v. 14, n. 6, p. 441-449, 2004.

CHUNG, C.; BURDICK, J. A. Engineering cartilage tissue. Advanced Drug Delivery Reviews, v. 60, n. 2, p. 243-262, 2008.

CIMMINO, M. A.; SARZI-PUTTINI, P.; SCARPA, R.; CAPORALI, R.; PARAZZINI, F.; ZANINELLI, A.; MARCOLONGO, R. Clinical Presentation of Osteoarthritis in General Practice: Determinants of Pain in Italian Patients in the AMICA Study. Seminars in Arthritis and Rheumatism, v. 35, p. 17-26, 2005.

COOMBES, A. G.; RIZZI, S. C.; WILLIAMSON, M.; BARRALET, J. E.; DOWNES, S.; WALLACE, W. A. Precipitation casting of polycaprolactone for applications in tissue engineering and drug delivery. Biomaterials, v. 25, n. 2, p. 315-325, 2004. 
COSTA, M.; BUENO, D. F.; MARTINS, M. T.; KERKIS, I.; KERKIS, A.; FANGANIELLO, R. D. D.; CERRUTI, H.; ALONSO, N.; PASSOS-BUENO M. R. Reconstruction of large cranial defects in nonimmunosuppressed experimental design with human dental pulp stem cells. The Journal of Craniofacial Surgery, v. 19, p. 204-210, 2008.

CURL, W.W.; KROME, J.; GORDON E.S.; SMITH, B. P.; POEHLING, G. G. Cartilage injuries: a review of 31,516 knee arthroscopies. Arthroscopy. v.13, p.456-460, 1997.

CZAJA, W. K.; YOUNG, D. J.; KAWECKI, M.; BROWN, R. M. The future prospects of microbial cellulose in biomedical applications. Biomacromolecules, v. 8, n. 1, p. 1-12, 2007.

D`AQUINO, R.; PAPACCIO, G.; LAINO, G.; GRAZIANO, A. Dental pulp stem cells: a promising tool for bone regeneration. Stem Cells Review, v. 4, p. 21 $26,2008$.

DALBY, M. J.; DI SILVIO, L.; HARPER, E. J.; BONFIELD, W. Initial interaction of osteoblasts with the surface of a hydroxyapp.atite-poly(methylmethacrylate) cement. Biomaterials, v. 22, n. 13, p. 1739-1747, 2001.

DE ROSIS, R. G.; MASSABKI, P. S.; KAIRALLA, M. Osteoartrite: avaliação clínica e epidemiológica de pacientes idosos em instituição de longa permanência. Revista Brasileira de Clinica Médica. v. 8, n. 2, p. 101-108, 2010.

DETSCH, R.; MAYR H.; ZIEGLER, G. Formation of osteoclast-like cells on HA and TCP ceramics. Acta Biomater, v. 4, n. 1, p. 139-148, 2008.

DEVINE, S. M.; COBBS, C.; JENNINGS, M.; BARTHOLOMEW, A.; HOFFMAN, R. Mesenchymal stem cells distribute to a wide range of tissues following systemic infusion into nonhuman primates. Blood, v. 101, n. 8, p. 2999-3001, 2003. 
DI MARTINO, A.; SITTINGER, M.; RISBUD, M.V. Chitosan: a versatile biopolymer for orthopaedic tissue-engineering. Biomaterials, v. 26, n. 30, p. 5983-5990, 2005.

ELISSEEFF, J.; PULEO, C.; YANG, F.; SHARMA, B. Advances in skeletal tissue engineering with hydrogels. Orthodontics and craniofacial research, v. 8, p. 150-161, 2005.

FELLET, A.; FELLET, A. J.; FELLET, L. Osteoartrose: uma revisão. Revista Brasileira de Medicina, v. 64, p. 55-61, 2007.

FERREIRA, L. M.; HOCHAM, B.; BARBOSA, M. V. J. Modelos experimentais em pesquisa. Acta Cirúrgica Brasileira. v. 20 p. 28-34, 2005

FRENKEL, S. R.; BRADICA, G.; BREKKE, J. H.; GOLDMAN, S. M.; IESKA, K.; ISSACK, P.; BONG, M. R.; TIAN, H.; GOKHALE, J.; COUTTS, R. D.; KRONENGOLD, R. T. Regeneration of articular cartilage-evaluation of osteochondral defect repair in the rabbit using multiphasic implants. Osteoarthritis Cartilage, v. 13, p. 798-807, 2005.

FUCHS, E.; SEGRE, J. Stem Cell: A new lease on life. Cell, v. 100, p. 143155, 2000.

GAISSMAIER, C.; FRITZ, J.; SCHEWE, B.; WEISE, K. MOLLENHAUER, J. AICHER, W. K. Cartilage Defects: Epidemiology and Natural History. Osteo Trauma Care, v.14, p.188-194, 2006.

GARRY, D. J.; MASINO, A. M.; MEESON, A. P.; MARTIN, C. M. Stem cell biology and therapeutic applications. Current opinion in nephrology \& hypertension, v. 12, p. 447-454, 2003.

GOMES, M.; AZEVEDO, H.; MALAFAYA, P.; SILVA, S. Natural polymers in tissue engineering applications. In: VAN BLITTERSWIJK, C.; LINDHAL, A.; 
THOMSEM, P.; OLIVEIRA, J.; SILVA, G.; SOUSA, R.; MANO, J.; REIS, R., (Ed) Tissue engineering: Canadá. Elsevier; 2008. p. 145-192.

GRONTHOS, S.; BRAHIM, J.; LI, W.; FISHER, L. W.; CHERMAN, N.; BOYDE, A.; DENBESTEN, P.; ROBEY, P.; ROBEY, P. G.; SHI, S. Stem cell properties of human dental pulp stem cells. Journal of Dental Research, v. 81, p. 531535, 2002.

GRONTHOS, S.; MANKANI, M.; BRAHIM, J.; ROBEY, P. G.; SHI, S. Postnatal human dental pulp stem cells (DPSCs) in vitro and in vivo. Proceedings of the National Academy of Sciences of the United States of America, v. 97, p. 13625-13630, 2000.

GUMBINER, B. M. Cell adhesion: the molecular basis of tissue architecture and morphogenesis. Cell, v. 84, n. 3, p. 345-357, 1996.

HAU, G. R.; LOPEZ, C. M. L.; BALDANI, M. H.; GARBELINI, M. C. L.; PAULETTO, C. A.; LEAL, G. A.; SLUSARZ, P. A. A. Revisão preliminar sobre a viabilidade de utilização de células-tronco provenientes de dentes humanos decíduos e permanentes na regeneração tecidual. Publicativo da Universidade Estadual de Ponta Grossa - Ciências Biológicas e da Saúde, v. 12, p. 47-55, 2006.

HELMUS, M. N.; GIBBONS, D. F.; CEBON, D. Biocompatibility: meeting a key functional requirement of next-generation medical devices. Toxicologic Pathology, v. 36, n. 1, p. 70-80, 2008.

HJELLE, K.; SOLHEIM, E.; STRAND, T.; MURI, R.; BRITTBERG, M. Articular cartilage defects in 1.000 knee arthoscopies. Arthroscopy. v. 18, p. 730-734, 2002.

HOLY, C. E.; et al. In vivo models for bone tissue-engineering constructs. In: Davies J, editor. Bone Engineering. Toronto: Copyright; 2000. p. 496-504. 
HSIEH, C. Y.; TSAI, S. P.; HO, M. H.; WANG, D. M.; LIU, C. E.; HSIEH, C.H.; TSENG, H. C.; HSIEHAL, H. J. Analysis of freeze-gelation and cross-linking processes for preparing porous chitosan scaffolds. Carbohydrate polymers, v. 67, n. 1, p. 124-32, 2007.

HUANG, J. I.; KAZMI, N.; DURBHAKULA, M. M.; HERING, T. M.; YOO, J. U.; JOHNSTONE, B. Chondrogenic potencial of progenitor cells derived from human bone marrow and adipose tissue: A patient-matched comparison. Journal of Orthopoedic Research, v. 23, p. 1383-1389, 2005.

HUNG, C. T.; MAUCK, R. L.; WANG, C. C. B.; LIMA, E. G.; ATESHIAN, G. A. $A$ paradigm for functional tissue engineering of articular cartilage via applied physiologic deformational loading. Annals of Biomedical Engineering, v. 32, n. 1, p. 35-49, 2004.

JOHNSON, L. L. Arthoscopic abrasion arthroplasty historical and pathologic perspective: Present status. Arthroplasty. v. 2, p. 54, 1986.

KAM, Z.; DIAS, J. M. D.; ABREU, N. S.; DIAS, R. C. Nível de atividade física, dor e edema e suas relações com a disfunção muscular do joelho de idosos com osteoartrite. Revista Brasileira de Fisioterapia, São Carlos, v. 10, n. 3 , p. 279-284, 2006.

KEATING, A. Mesenchymal stromal cells. Current Opinion in Hematology, v. 13, p. 419-425, 2006.

KERKIS, I.; AMBRÓSIO, C. E.; KERKIS, A.; MARTINS, D. S.; ZUCCONI, E.; FONSECA, S. A. S.; CABRAL, R. M.; MARANDUBA, C. M. C.; GAIAD, T. P.; MORINI, A. C.; VIEIRA, N. M.; BRÓLIO, M. P.; SANT'ANNA, O. A.; MIGLINO, M. A.; ZATS, M. Early transplantation of human immature dental pulp stem cells from baby teeth to golden retriever muscular dystrophy (GRMD) dogs: local or systemic? Journal of Translational Medicine, v. 6, p. 36, 2008. 
KERKIS, I.; KERKIS, A.; DOZORTSEV, D.; STUKART-PARSONS, G. C.; MASSIRONI, S. M. G.; PEREIRA, L. V.; CAPLAN, A. I.; CERRUTI, H. F. Isolation and characterization of a population of immature dental pulp stem cells expressing OCT-4 and embryonic stem cell markers. Cells Tissue Organs, v. 184, p. 105-116, 2006.

KHOR, E. Chitin: fulfilling a biomaterials promise. 1st ed. Amsterdam: Elsevier; 2001.

KIRSCHSTEIN, R.; SKIRBOLL, L. The stem cells. Stem cells: Scientific progress and future research directions. United States. National Institutes of Health, 2001. p. 1-3.

KOGA, H.; SHIMAYA, M.; MUNETA, T.; NIMURA, A.; MORITO, T.; HAYASHI, M.; SUZUKI, S.; JU, Y.; MOCHIZUKI, T.; SEKIYA, I. Local adherent technique for transplanting mesenchymal stem cells as a potential treatment of cartilage defect. Arthritis Research \& Therapy. v.10, n.4, p. 1-10, 2008.

KUMARI, T. V.; VASUDEV, U.; KUMAR, A.; MENON, B. Cell surface interactions in the study of biocompatibility. Trends in Biomaterials and Artificial Organs, v. 15, n. 2, p. 37-41, 2002.

LAINO, G.; D'AQUINO, R.; GRAZIANO, A.; LANZA, V.; CARINCI, F.; NARO, F.; PIROZZI, G.; PAPACCIO, G. A new population of human adult dental pulp stem cells: a useful source of living autologous fibrous bone tissue (LAB). Journal of Bone and Mineral Research, v. 20, p. 394-402, 2005.

LEAL, S. C. Células-tronco derivadas de polpa dentária humana: propriedades e perspectivas. Revista Dental Press Ortodontia e Ortopedia Facial, v. 12, n. 4, p. 17-18, 2007.

LEE, H. S.; HUANG, G. T.; CHIANG, H.; CHIOU, L. L.; CHEN, M. H.; HSIEH, C. H.; JIANG, C. C. Multipotencial mesenchymal stem cells from femoral bone marrow near the site of osteonecrosis. Stem Cells, v. 21, p. 190-199, 2003. 
LEITE SEGUNDO, A. V.; VASCONCELOS, E. C. E. Células-tronco e engenharia tecidual: perspectivas de aplicação em odontologia. Revista de Ciência Médica, v. 16, n. 1, p. 23-30, 2007.

LEVIN, L. A.; RITCH, R.; RICHARDS, J. E.; BORRÁS, T. Stem cell therapy for ocular disorders. Archive of Ophthalmology, v. 122, p. 621-627, 2004.

LO, K. C.; CHUANG, W. W.; LAMB, D. Stem cell research: the facts, the myths and the promises. The Journal of Urology, v. 170, p. 2453-2458, 2003.

LOBO, S. E. Avaliação histomorfométrica da regeneração do tecido ósseo utilizando-se biocerâmica de hidroxiapatita e beta-tricálcio fosfato associada ou não ao concentrado de plaquetas: estudo em coelhos New Zealand. 2002. 172f. Dissertação (Mestrado) - Universidade Federal de Minas Gerais, Belo Horizonte, 2002.

LOBO, S. E.; WYKROTA, F. H.; OLIVEIRA, A. C.; KERKIS, I., MAHECHA, G. B.; ALVES, H. J. Quantification of bone mass gain in response to the application of biphasic bioceramics and platelet concentrate in critical-size bone defects. Journal of Material Science. Material Medicine, v. 20, n. 5, p. 1137-1147, 2008.

LOTTENBERG, C. L.; MOREIRA FILHO, C. A. Aplicações terapêuticas das células-tronco perspectivas e desafios. Disponível em: <http://www.comciencia.br/reportagens/celulas/14.shtml> Acesso em: 04 jan. 2009.

LUTOLF, M. P.; HUBBELL, J. A. Synthetic biomaterials as instructive extracellular microenvironments for morphogenesis in tissue engineering. Nature Biotechnology, v. 23, n. 1, p. 47-55, 2005.

LUYTEN, F.P. Mesenchymal stem cells in osteoarthritis. Current Opinions of Rheumatology, v. 16, p. 599-603, 2004. 
MALAFAYA, P.B.; REIS, R.L. Bilayered chitosan-based scaffolds for osteochondral tissue engineering: Influence of hydroxyapatite on in vitro cytotoxicity and dynamic bioactivity studies in a specific double-chamber bioreactor. Acta Biomaterials. v. 5, n. 2, p. 644-660, 2009.

MANGGOLD, J.; SERGI, C.; BECKER, K.; LUKOSCHEK, M.; SIMANK, H. G. A new animal model of femoral head necrosis induced by intraosseus injection of ethanol. Laboratory Animals, v. 36, p. 173-180, 2002.

MANKANI, M. H.; KUZNETSOV, S. A.; WOLFE, R. M.; MARSHALL, G. W.; ROBEY, P. G. In vivo bone formation by human bone marrow stromal calls: rereconstruction of the mouse calvarium and mandible. Stem Cells, v. 24, p. 2140-2149, 2006.

MARTIN DF. Pathomechanics of knee osteoarthritis. Medicine Science Sports Exercises. v. 12, n. 26, p. 1429-1434, 1994.

MARTINEK, V.; FU, F. H.; HUARD, J. Gene therapy and tissue engineering in sports medicine. Physician Sportsmed, v. 28, p. 34-51, 1999.

MI, F.L.; TAN, Y. C.; LIANG, H. F.; SUNG, H. W. In vivo biocompatibility and degradability of a novel injectable-chitosan-based implant. Biomaterials, $v$. 23, n. 1, p. 181-191,2002.

MIURA, M.; GRONTHOS, S.; ZHAO, M.; LU, B.; FISHER, L. W. ROBEY, P. G.; SHI, S.; SHED: Stem cell from human exfoliated deciduous teeth. Proceedings of the National Academy of Sciences. v. 100, p. 5807-5812, 2003.

MONTEIRO, B. G.; SERAFIM, R. C.; MELO, G. B.; SILVA, M. C. P.; LIZIER, N. F.; MARANDUBA, C. M. C.; SMITH, R. L.; KERKIS, A.; CERRUTI, H.; GOMES, J. A. P.; KERKIS, I. Human immature dental pulp stem cells share key characteristic features with limbal stem cells. Cell Proliferation, v. 42, n. 5, p. 587-594, 2009. 
MRUGALA, D.; BONY, C.; NEVES, N.; CAILLOT, L.; FABRE, S.; MOUKOKO, D.; JORGENSEN, C.; NOËL, D. Phenotypic and functional characterization of ovine mesenchymal stem cells: application to a cartilage defect model. Annais of Rheumathis Diseases, v. 67, n. 3, p. 288-295, 2007.

MRUGALA, D.; BONY, C.; NEVES, N.; CAILLOT, L.; FABRE, S.; MOUKOKO, D.; JORGENSEN, C. AND NOËL, D. Phenotypic and functional characterisation of ovine mesenchymal stem cells: application to a cartilage defect model. Annals of the Rheumatic Diseases. v. 67 p. 288-295, 2008.

MURPHY, J. M.; FINK, D. J.; HUNZIKER, E. B.; BARRY, F. P. Stem cell therapy in a caprine model of osteoarthritis. Arthritis Rheumatology, v. 48, n. 12, p. 3464-3474, 2003.

MUZZARELLI, R. A. A.; ZUCCHINI, C. ILARI, P.; PUGNALONI, A.; BELMONTE, M. M.; BIAGINI, G.; CASTALDINI, C. Osteoconductive properties of methylpyrrolidinone chitosan in an animal model. Biomaterials, v. 14, n. 12, p. 925-929, 1993.

NARDI, N. B.; MEIRELLES, L. S. Mesenchymal stem cells: isolation, in vitro expansion and characterization. Handbook of Experimental Pharmacology, v. 174, p. 249-282, 2006.

NOLAN, K.; MILLET, Y.; RICORDI, C.; STABLER, C. Tissue engineering and biomaterials in regenerative medicine. Cell Transplantation, v. 16, p. 241243, 2008.

OKAMOTO, K. O.; MOREIRA FILHO, C. A. Células Tronco: genômica funcional e aplicações terapêuticas. In Genômica. Atheneu: São Paulo, p. 311-326, 1 ed. 2004.

OLIVEIRA, C.S.; NASCIMENTOS, M.; JUNIOR, E.A.; BAHIA, M.C.P.; ROSA, F.P. Avanços e aplicações da bioengenharia tecidual. Revista de Ciências Médicas e Biológicas. v.9, p.28-36, 2010. 
OREFFO, R. O. C.; TRIFFITT, J.T. Future potencials for using osteogenic stem cells and biomaterials in orthopedics. Bone, v. 25, p. 5S-9S, 1999.

OSATHANON, T.; LINNES, M. L.; RAJACHAR, R. M.; RATNER, B.D.; SOMERMAN, M. J.; GIACHELLI, C. M. Microporous Nanofibrous Fibrin-based Scaffolds for Bone Tissue Engineering. Biomaterials. v.29, n.30, p.40914099, 2008.

OTAKI, S. UESHIMA, S.; SHIRAISHI, K.; SUGIYAMA, K.; HAMADA, S.; YORIMOTO, M.; MATSUO, O. Mesenchymal progenitor cells in adult human dental pulp and their ability to from boné when transplanted into immunocompromised mice. Cell Biology International, v. 31, p. 1191-1197, 2007.

OTTE, P. Physiologie der Gelenkerhaltung. In: OTTE, P.; Der ArthroseProzess. Gelenkerhaltung - Gefahrdung - Destruktion. Teil 1: Osteochondrale Strukturen. Numberg:Novartis Pharma Verlag, p.7-192, 2000.

PEREIRA, D. B. Complicação durante artroscópia do joelho usando bomba de infusão: relato de caso. Revista Brasileira de Ortopedia, v. 37, n. 08, p. 366367, 2002.

PEREIRA, D.B. Complicação durante artroscópia do joelho usando bomba de infusão: relato de caso. Revista Brasileira de Ortopedia. São Paulo. v. 37, n. 08, p. $366-367,2002$.

PIERDOMENICO, L.; BONSI, L.; CALVITTI, M.; RONDELLI, D.; ARPINATI, M.; CHIRUMBOLO, G.; BECCHETTI, E.; MARCHIONNI, C.; ALVIANO, F.; FOSSATI, V.; STAFFOLANI, N.; FRANCHINA, M.; GROSSI, A.; BAGNARA, G.P. Multipotent mesenchymal stem cells with immunosuppressive activity can be easily isolated from dental pulp. Transplantation v. 80, p. 836-842, 2005. 
QI, J.; CHEN, A.; YOU, H.; LI, K.; ZHANG, D.; GUO, F. Proliferation and chondrogenic differentiation of CD105-positive enriched rat synovium-derived mesenchymal stem cells in three-dimensional porous scaffolds. Biomedical Materials. v. 6. 2011.

RATNER, B. D. Biomaterials science: an introduction to materials in medicine. 2. ed. Amsterdam Boston: Elsevier Academic Press, 2004.

RIPAMONTI, U. The morphogenesis of bone by intrinsic ostroinductive biomaterials Geometric induction of bone differentiation. In: WORLD BIOMATERIALS CONGRESS; (6), 2000, Havaí. Kamuela: (s.n.), 2000.

SCADDEN D. T. The stem-cell niche as an entity of action. Nature, v. 441, p. 1075-1079, 2006.

SCHAGEMANN, J. C.; CHRISTOPH, M. D. CHUNG, H. W.; LAHM, A.; KURZ, H.; MROSEK, E. H. Cell-Laden and Cell-Free Biopolymer Hydrogel for the Treatment of Osteochondral Defects in a Sheep Model. Tissue Engineering. v. 15, p. 75-82, 2009.

SERRANO, M. C.; PAGANI, R.; VALLET-REGI, M.; PENA, J.; RAMILA, A.; IZQUIERDO, I.; PORTOLES, M. T. In vitro biocompatibility assessment of poly (epsilon-caprolactone) films using L929 mouse fibrobiasts. Biomaterials, v. 25, n. 25, p. 5603-5611, 2004.

SHARMA, B.; ELISSEEFF, J. H. Engineering structurally organized cartilage and bone tissues. Annais of Biomedical Engineering, v. 32, n. 1, p. 148159, 2004.

SHARMA, B.; WILLIAMS, C. G.; KIM, T. K.; SUN, D. MALINK, A.; KHAN, M. LEONG, K.; ELISSEEFF, J. H. Designing zonal organization into tissueengineered cartilage. Tissue Engineering, v. 13, n. 2, p. 405-414, 2007. 
SILVA, F.; LAMY, E.; REIS, J. C.; POTES, J. C.; PEREIRA, A.; CABRITA, S. A. Expressão imunoistoquímica da proteína $S-100$ na discondroplasia da tíbia. Arquivo Brasileiro de Medecina Veterinária e Zootecnia. v. 62, n. 2, p. $495-$ 498, 2010.

SLOAN, A. J.; SMITH, A. J. Stem cells and the dental pulp: potential roles in dentine regeneration and repair. Oral Diseases, v. 13, p. 151-157, 2007.

SRIKANTH, V. K.; FRYER, J. L.; ZHAI, G.; WINZENBERG, T. M.; HOSMER, D.; JONES, G. A meta-analysis of sex differences prevalence, incidence and severity of osteoarthritis. Osteoarthritis Cartilage, v. 13, n. 9, p. 769-781, 2005.

TAPPER, J. E.; FUKUSHIMA, S.; AZUMA, H.; SUTHERLAND, C.; MARCHUK, L.;THORNTON, G. M.; RONSKY, J. L.; ZERNICKE, R.; SHRIVE, N. G.; FRANK, C.B. Dynamic In Vivo Three-Dimensional (3D) Kinematics of the Anterior Cruciate Ligament/Medial Collateral Ligament Transected Ovine Stifle Joint. Wiley InterScience. v. 26 p. 660-672, 2008.

THOMSON, J. A.; ITSKOVITZ-ELDOR, J.; SHAPIRO, S. S.; WAKNITZ, M. A.; SWIERGIEL, J. J.; MARSHALL, V. S.; JONES, J. M. Embryonic stem cell lines derived from human blastocysts. Science, v. 282, n. 5391, p. 1145-1147, 1998.

TORQUETTI, L.; CASTANHEIRA, P.; DE GOES, A. M.; MARCIO, N. Stem cells:potential source for retinal repair and regeneration. Arquivo Brasileiro de Oftalmologia, v. 70, n. 2, p. 371-375, 2007.

VACHON, A. M.; MCLLWRAITH, C. W.; POWERS, B. E.; MCFADDEN, P. R.; AMIEL, D. Sternal cartilage autografts for resurfacing induced osteochondral defects in horses: A morphologic and biochemical study. Veterinary Surgery. v. 20, p. 350, 1991. 
VANDEVORD, P. J.; MATTHEW, H. W.; DESILVA, S. P.; MAYTON, L.; WU, B.; WOOLEY, P. H. Evaluation of the biocompatibility of a chitosan scaffold in mice. Journal of Biomedical Material Research, v. 59, n. 3, p. 585-590, 2002.

VARGHESE, S.; HWANG, N. S.; CANVER, A. C.; THEPRUNGSIRIKUL, P.; LIN, D. W.; ELISSEEF, J. Chondroitin sulfate based niches for chondrogenic differentiation of mesenchymal stem cells. Matrix Biology, v. 27, n. 1, p. 1221, 2008.

WAGERS, S. J.; WEISSMAN, I. L. Plasticity of adult stem cells. Cell, p. 116, n. 5, p. 639-648, 2004.

WAHL, S. M. Transforming growth factor beta: the good, the bad, and the ugly. Journal of Experimental Medicine, v. 180, n. 5, p. 1587-1590, 1994.

WAKITANI, S.; GOTO, T.; YOUNG, R. G.; MANSOUR, J. M.; GOLDERG, V. M.; CAPLAN, A. I. Repair of large full-thickness articular cartilage defects with allograft articular chondrocytes embedded in a collagen gel. Tissue Engineer. v. 4 , p. $429,1998$.

WAKITANI, S.; KIMURA, T. HIRROOKA, A.; OCHI, T.; YONEDA, M.; YASUI, N. OWAKI, H.; ONO, K. Repair of rabbit articular surface with allograft chondrocytes embedded in collagen gel. Journal Joint Surgery. v. 71, p. 74, 1989.

WANG, M. Developing bioactive composite materials for tissue replacement. Biomaterials, v. 24, n. 13, p. 2133-2151, 2003.

WILLIAMS, D. F. On the mechanisms of biocompatibility. Biomaterials, v. 29, n. 20, p. 2941-2953, 2008.

XIMIN, G.; CHANGYONG, W.; YUFU, Z.; RENYUN, X.; MIN, H;QIANG, Z.; LINGZHI, D.; JIANXI, L.; YIN, Q. S. Repair of Large Articular Cartilage Defects with Implants of Autologous Mesenchymal Stem Cells Seeded into $\beta$ - 
Tricalcium Phosphate in a Sheep Model. Tissue Engineering. v. 10, p. 18181829, 2004.

YAMAMURA, T. Differentiation of pulpal cells and inductive influences of various matrices with reference to pulpal wound healing. Journal of Dental Research, v. 64, p. 530-540, 1985.

YU, J.; WANG, U.; DENG, Z.; TANG, L.; LI, Y.; SHI, J.; JIN, Y. Odontogenic capacity: bone marrow stromal stem cells versus dental pulp stem cells. Biology Cell, v. 99, p. 465-474, 2007.

ZATZ, M. Clonagem e células-tronco. Estudos Avançados, v. 18, n. 51, p. 247-256, 2004. 